Cochrane Database of Systematic Reviews

\title{
Corticosteroids as adjunctive therapy in the treatment of influenza
} (Review)

Lansbury L, Rodrigo C, Leonardi-Bee J, Nguyen-Van-Tam J, Lim WS

Lansbury L, Rodrigo C, Leonardi-Bee J, Nguyen-Van-Tam J, Lim WS.

Corticosteroids as adjunctive therapy in the treatment of influenza.

Cochrane Database of Systematic Reviews 2019, Issue 2. Art. No.: CD010406.

DOI: 10.1002/14651858.CD010406.pub3.

www.cochranelibrary.com 
TABLE OF CONTENTS

HEADER 1

ABSTRACT

PLAIN LANGUAGE SUMMARY

SUMMARY OF FINDINGS

BACKGROUND

OBJECTIVES

METHODS

RESULTS

Figure 1.

Figure 2.

Figure 3.

Figure 4.

Figure 5.

DISCUSSION

AUTHORS' CONCLUSIONS

ACKNOWLEDGEMENTS

REFERENCES

CHARACTERISTICS OF STUDIES

DATA AND ANALYSES

Analysis 1.1. Comparison 1 Corticosteroid therapy versus no corticosteroid therapy, Outcome 1 Mortality following admission, hospitalised participants - studies reporting odds ratios.

Analysis 1.2. Comparison 1 Corticosteroid therapy versus no corticosteroid therapy, Outcome 2 Mortality following admission, hospitalised participants - studies reporting hazard ratios.

Analysis 1.3. Comparison 1 Corticosteroid therapy versus no corticosteroid therapy, Outcome 3 Adverse events secondary to corticosteroid use: hospital-acquired infection in hospitalised participants.

ADDITIONAL TABLES

APPENDICES

WHAT'S NEW

HISTORY

CONTRIBUTIONS OF AUTHORS

DECLARATIONS OF INTEREST

DIFFERENCES BETWEEN PROTOCOL AND REVIEW

INDEX TERMS 
[Intervention Review]

\section{Corticosteroids as adjunctive therapy in the treatment of influenza}

Louise Lansbury ${ }^{1}$, Chamira Rodrigo², Jo Leonardi-Bee³, Jonathan Nguyen-Van-Tam4, Wei Shen Lim²

1Department of Epidemiology and Public Health, The University of Nottingham, Nottingham, UK. 2Department of Respiratory Medicine, Nottingham University Hospitals Trust, Nottingham, UK. 3Division of Epidemiology and Public Health, The University of Nottingham, Nottingham, UK. ${ }^{4}$ Faculty of Medicine and Health Sciences, The University of Nottingham, Nottingham, UK

Contact address: Louise Lansbury, Department of Epidemiology and Public Health, The University of Nottingham, City Hospital Campus, Hucknall Road, Nottingham, NG5 1PB, UK. louise.lansbury@nottingham.ac.uk.

Editorial group: Cochrane Acute Respiratory Infections Group.

Publication status and date: Edited (no change to conclusions), published in Issue 9, 2019.

Citation: Lansbury L, Rodrigo C, Leonardi-Bee J, Nguyen-Van-Tam J, Lim WS. Corticosteroids as adjunctive therapy in the treatment of influenza. Cochrane Database of Systematic Reviews 2019, Issue 2. Art. No.: CD010406. DOI: 10.1002/14651858.CD010406.pub3.

Copyright @ 2019 The Cochrane Collaboration. Published by John Wiley \& Sons, Ltd.

\section{A B S T R A C T}

\section{Background}

Specific treatments for influenza are limited to neuraminidase inhibitors and adamantanes. Corticosteroids show evidence of benefit in sepsis and related conditions, most likely due to their anti-inflammatory and immunomodulatory properties. Although commonly prescribed for severe influenza, there is uncertainty over their potential benefits or harms. This is an update of a review first published in 2016.

\section{Objectives}

To systematically assess the effectiveness and potential adverse effects of corticosteroids as adjunctive therapy in the treatment of influenza, taking into account differences in timing and doses of corticosteroids.

\section{Search methods}

We searched CENTRAL (2018, Issue 9), which includes the Cochrane Acute Respiratory infections Group's Specialised Register, MEDLINE (1946 to October week 1, 2018), Embase (1980 to 3 October 2018), CINAHL (1981 to 3 October 2018), LILACS (1982 to 3 October 2018), Web of Science (1985 to 3 October 2018), abstracts from the last three years of major infectious disease and microbiology conferences, and references of included articles. We also searched the World Health Organization International Clinical Trials Registry Platform, ClinicalTrials.gov, and the ISRCTN registry on 3 October 2018.

\section{Selection criteria}

We included randomised controlled trials (RCTs), quasi-RCTs, and observational studies that compared corticosteroid treatment with no corticosteroid treatment for influenza or influenza-like illness. We did not restrict studies by language of publication, influenza subtypes, clinical setting, or age of participants. We selected eligible studies in two stages: sequential examination of title and abstract, followed by full text.

\section{Data collection and analysis}

Two review authors independently extracted data and assessed risk of bias. We pooled estimates of effect using a random-effects model, where appropriate. We assessed heterogeneity using the 12 statistic and assessed the certainty of the evidence using the GRADE framework.

\section{Main results}

This updated review includes 30 studies (one RCT with two arms and 29 observational studies) with a total of 99,224 participants. We included 19 studies in the original review $(n=3459)$, all of which were observational, with 13 studies included in the meta-analysis for 
mortality. We included 12 new studies in this update (one RCT and 11 observational studies), and excluded one study in the original review as it has been superceded by a more recent analysis. Twenty-one studies were included in the meta-analysis (9536 individuals), of which 15 studied people infected with 2009 influenza A H1N1 virus (H1N1pdm09). Data specific to mortality were of very low quality, based predominantly on observational studies, with inconsistent reporting of variables potentially associated with the outcomes of interest, differences between studies in the way in which they were conducted, and with the likelihood of potential confounding by indication. Reported doses of corticosteroids used were high, and indications for their use were not well reported. On meta-analysis, corticosteroid therapy was associated with increased mortality (odds ratio (OR) 3.90,95\% confidence interval (CI) 2.31 to $6.60 ; \mathrm{I}^{2}=68 \% ; 15$ studies). A similar increase in risk of mortality was seen in a stratified analysis of studies reporting adjusted estimates $(\mathrm{OR} 2.23,95 \% \mathrm{Cl} 1.54$ to 3.24 ; $\mathrm{I}^{2}=0 \% ; 5$ studies). An association between corticosteroid therapy and increased mortality was also seen on pooled analysis of six studies which reported adjusted hazard ratios (HRs) (HR 1.49, $95 \% \mathrm{Cl} 1.09$ to $2.02 ; \mathrm{I}^{2}=69 \%$ ). Increased odds of hospital-acquired infection related to corticosteroid therapy were found on pooled analysis of seven studies (pooled OR $2.74,95 \% \mathrm{Cl} 1.51$ to $4.95 ; \mathrm{I}^{2}=90 \%$ ); all were unadjusted estimates, and we graded the data as of very low certainty.

\section{Authors' conclusions}

We found one RCT of adjunctive corticosteroid therapy for treating people with community-acquired pneumonia, but the number of people with laboratory-confirmed influenza in the treatment and placebo arms was too small to draw conclusions regarding the effect of corticosteroids in this group, and we did not include it in our meta-analyses of observational studies. The certainty of the available evidence from observational studies was very low, with confounding by indication a major potential concern. Although we found that adjunctive corticosteroid therapy is associated with increased mortality, this result should be interpreted with caution. In the context of clinical trials of adjunctive corticosteroid therapy in sepsis and pneumonia that report improved outcomes, including decreased mortality, more high-quality research is needed (both RCTs and observational studies that adjust for confounding by indication). The currently available evidence is insufficient to determine the effectiveness of corticosteroids for people with influenza.

\section{PLAIN LANGUAGE SUMMARY}

\section{Steroids for the treatment of influenza}

\section{Review question}

We reviewed the evidence regarding the effect of additional ('adjunctive') steroid treatment in individuals with influenza infection.

\section{Background}

The majority of individuals with influenza have a fever, headache, and cough and improve without any specific treatment. However, a small proportion of patients develop a more severe form of influenza that requires admission to a hospital intensive care unit. These patients are often prescribed steroids as part of their treatment, although the evidence supporting the use of steroids in these circumstances is controversial.

\section{Study characteristics}

We searched for studies comparing additional steroid treatment with no additional steroid treatment in individuals with influenza. The evidence is current to 3 October 2018. We identified a total of 30 studies with 99,224 individuals; one of these studies was a clinical trial. The majority of studies investigated adults admitted to hospital with pandemic influenza in 2009 and 2010.

\section{Key results}

We found one relevant clinical trial, but there were very few participants $(n=24)$ with laboratory-confirmed influenza. The certainty of the evidence available from existing observational studies was of very low. We found that people with influenza who received additional steroid treatment may have a greater risk of death compared to those who did not receive steroid treatment. Hospital-acquired infection was the main 'side effect' related to steroid treatment reported in the included studies; most studies reported a greater risk of hospital-acquired infection in the group treated with steroids. However, it was unclear whether patients with more severe influenza had been selected to receive steroid treatment. Consequently, we were unable to determine whether additional steroid treatment in people with influenza is truly harmful or not. Further clinical trials of additional steroids in the treatment of individuals with influenza are therefore warranted. In the meantime, the use of steroids in influenza remains a clinical judgement call.

\section{Certainty of the evidence}

In the one controlled trial there were only 24 participants with confirmed influenza infection, and there was under-representation of the sickest patients in the intensive care unit and with sepsis.

The rest of the evidence was from observational studies, and we classified the certainty of this evidence as very low. A major limitation was that the indications for corticosteroid therapy were not fully specified in many of the studies; corticosteroids may have been used as a final attempt in people with the most severe disease, or conversely they may have been used to treat less severe illnesses that occurred simultaneously such as asthma exacerbations. It was noted in some studies that there was high degree of association between the use 
of corticosteroids and the presence of potentially confounding factors such as disease severity and underlying illnesses, suggesting that confounding by the indication for corticosteroids was likely if not adjusted for when determining effect estimates. We noted inconsistent reporting of other important variables that may be related to influenza-related death across studies, including time to hospitalisation, the use and timing of antiviral drugs and antibiotics, and the type, dose, timing, and duration of corticosteroid therapy. Additionally, for studies in which this information was reported, there were differences between studies in the way that disease severity was measured, the time point at which death was assessed, and the proportions of cases and controls treated with antivirals and/or antibiotics and in the type, dose, timing, and duration of corticosteroid therapy. 
SUMMARY OF FINDINGS

\section{Summary of findings for the main comparison. Corticosteroid therapy compared to no corticosteroid therapy in the treatment of influenza}

\section{Effect of corticosteroid therapy on influenza-related outcomes}

Patient or population: individuals with influenza

Setting: in-hospital

Intervention: corticosteroid therapy

Comparison: no corticosteroid therapy

\begin{tabular}{|c|c|c|c|c|c|}
\hline \multirow[t]{2}{*}{ Outcomes } & \multicolumn{2}{|c|}{ Anticipated absolute effects ${ }^{\star}(95 \% \mathrm{Cl})$} & \multirow{2}{*}{$\begin{array}{l}\text { Relative effect } \\
(95 \% \mathrm{CI})\end{array}$} & \multirow{2}{*}{$\begin{array}{l}\text { № of participants } \\
\text { (studies) }\end{array}$} & \multirow{2}{*}{$\begin{array}{l}\text { Certainty of } \\
\text { the evidence } \\
\text { (GRADE) }\end{array}$} \\
\hline & $\begin{array}{l}\text { Risk with no } \\
\text { corticosteroid } \\
\text { therapy }\end{array}$ & $\begin{array}{l}\text { Risk with corticosteroid } \\
\text { therapy }\end{array}$ & & & \\
\hline $\begin{array}{l}\text { Number of deaths at } 30 \text { days following admis- } \\
\text { sion (30-day mortality) }{ }^{a}\end{array}$ & 70 per 1000 & $\begin{array}{l}209 \text { per } 1000 \\
(160 \text { to } 267)\end{array}$ & $\begin{array}{l}\text { OR } 3.90 \\
(2.31 \text { to } 6.60)^{b}\end{array}$ & $\begin{array}{l}9536 \\
\text { ( } 21 \text { observational stud- } \\
\text { ies) }\end{array}$ & $\begin{array}{l}\oplus \ominus \ominus \ominus \\
\text { VERY LOWC }\end{array}$ \\
\hline Rate of admission to intensive care units & 260 per 1000 & 643 per 1000 (599 to 684$)$ & OR 5.13 ( 4.26 to 6.17 ) & $\begin{array}{l}2141 \\
\text { (1 observational study) }\end{array}$ & $\begin{array}{l}\oplus \ominus \ominus \ominus \\
\text { VERY LOWd }\end{array}$ \\
\hline $\begin{array}{l}\text { Number and nature of adverse events sec- } \\
\text { ondary to corticosteroid use (hospital-acquired } \\
\text { infection) }\end{array}$ & 72 per 1000 & 175 per 1000 (105 to 277$)$ & OR 2.74 ( 1.51 to 4.95$)$ & $\begin{array}{l}6114 \\
\text { ( } 7 \text { observational stud- } \\
\text { ies) }\end{array}$ & $\begin{array}{l}\oplus \ominus \ominus \ominus \\
\text { VERY LOWe }\end{array}$ \\
\hline $\begin{array}{l}\text { Proportion of participants requiring mechani- } \\
\text { cal ventilation }\end{array}$ & 418 per 1000 & $\begin{array}{l}\text { Ranged from } 561 \text { to } 890 \\
\text { per } 1000\end{array}$ & $\begin{array}{l}\text { OR ranged from } 1.78(1.35 \\
\text { to } 2.35) \text { to } 11.29(8.25 \text { to } \\
15.44) .\end{array}$ & $\begin{array}{l}4364 \\
\text { ( } 4 \text { observational stud- } \\
\text { ies) }\end{array}$ & $\begin{array}{l}\oplus \odot \odot \ominus \\
\text { VERY LOWf }\end{array}$ \\
\hline
\end{tabular}

${ }^{\star}$ The risk in the intervention group (and its 95\% confidence interval) is based on the assumed risk in the comparison group and the relative effect of the intervention (and its $95 \% \mathrm{Cl}$ ).

Cl: confidence interval; OR: odds ratio

\section{GRADE Working Group grades of evidence}

High certainty: We are very confident that the true effect lies close to that of the estimate of the effect.

Moderate certainty: We are moderately confident in the effect estimate: the true effect is likely to be close to the estimate of the effect, but there is a possibility that it is

substantially different.

Low certainty: Our confidence in the effect estimate is limited: the true effect may be substantially different from the estimate of the effect.

Very low certainty: We have very little confidence in the effect estimate: the true effect is likely to be substantially different from the estimate of effect. 
Stratification by 30-day mortality was not possible due to heterogeneity between studies in reporting the timing of mortality after hospital admission.

bAdjusted OR only 2.23 ( $95 \%$ Cl 1.54 to 3.24; 1206 participants; 5 studies); adjusted HR only 1.49 ( $95 \%$ Cl 1.09 to 2.02; 7324 participants; 6 studies).

cPooled analysis. We downgraded the certainty of the evidence from low (observational data) to very low due to high risk of indication bias (sicker adults with influenza were

more likely to receive corticosteroids) and clinical/statistical heterogeneity (unadjusted estimates of odds ratio for mortality were presented in some studies, and the definition

of mortality varied across the studies).

dSingle observational study. We downgraded the certainty of the evidence from low (observational data) to very low due to high risk of indication bias (sicker adults with influenza

were more likely to receive corticosteroids). One single randomised controlled trial of corticosteroid use versus placebo with subgroup analysis of people with confirmed influenza was not powered for this outcome, and the number of participants in each arm was very small.

epooled analysis. We downgraded the certainty of the evidence from low (observational data) to very low due to high risk of indication bias (sicker adults with influenza were more likely to receive corticosteroids) and clinical/statistical heterogeneity (unadjusted estimates of odds ratio for hospital-acquired infection were presented in some studies, and the definitions of hospital-acquired infection varied across the studies).

${ }^{f}$ Results were not pooled. We downgraded the certainty of the evidence from low (observational data) to very low due to high risk of indication bias (sicker adults with influenza were more likely to receive corticosteroids) and clinical/statistical heterogeneity (unadjusted estimates of odds ratio for mechanical ventilation were presented in all studies). 


\section{B A C K G R O U N D}

\section{Description of the condition}

Influenza is a significant cause of morbidity and mortality worldwide and has a high financial burden. Seasonal influenza occurs annually during the winter months in temperate zones of both the Northern and Southern hemispheres and year round in the tropics (Caini 2016). Global estimates of seasonal influenza from the World Health Organization (WHO) report 1000 million cases, including three to five million cases of severe illness annually (WHO 2018). Between 291,000 and 645,800 respiratory deaths associated with influenza are estimated to occur globally each influenza season; $58 \%$ of these are in individuals aged 65 years and above (Iuliano 2018). The reported per capita total cost of a case of influenza illness in national studies ranges from USD 27 to USD 52 in European countries and USD 45 to USD 63 in the United States (Peasah 2013). Estimates of the influenza-related hospitalisation rate in the USA range from 63 to 107 per 100,000 individuals annually at a cost of USD 11,096 to USD 83,216 per admission; amongst adults, hospitalisation rates are highest in individuals aged 65 years age and above $(309 / 100,000)$ (Peasah 2013; Zhou 2012). The population-based incidence estimate for influenzaassociated critical illness in the USA is 12 per 100,000 person-years; this represents $1.3 \%$ of all critical illness hospitalisations, or $3.4 \%$ of critical illness hospitalisations during the influenza season (Ortiz 2014). Estimates from the UK indicate an influenza-attributable annual general practitioner consultation rate of 2156 per 100,000 population and a corresponding annual hospitalisation rate of 34 per 100,000 population (Cromer 2014).

Pandemic influenza occurs unpredictably and infrequently due to reassortment of the influenza virus or adaptive mutation of a virus that has crossed the species barrier (Taubenberger 2008). Although the case fatality ratio associated with the recent influenza $A(\mathrm{H} 1 \mathrm{~N} 1)$ pandemic in 2009 and 2010 was lower in comparison to previous pandemics (0.03\% versus $2.5 \%$ in 1918 and 1919 ) (Donaldson 2010), a modelling study of global mortality due to the recent pandemic estimated 201,200 respiratory deaths and 83,300 cardiovascular deaths, with $80 \%$ of the deaths in individuals younger than 65 years (Dawood 2012). This shift in mortality towards younger age groups is estimated to have led to between 334,000 and 1,973,000 'years of life lost' in the USA alone (Viboud 2010). Worldwide clinical data from the influenza $A(H 1 N 1)$ pandemic in 2009 revealed that more than one-fifth of hospitalised individuals experienced severe disease requiring admission to an intensive care unit (ICU) (Jain 2009; Muthuri 2013; Richard 2012). The onset of critical illness following hospital admission occurred rapidly (median one day) and was commonly due to acute respiratory distress syndrome with refractory hypoxaemia, septic shock, and/or multisystem organ failure, often requiring prolonged ventilation (Jain 2009; Kumar 2009). Critical care delivery systems were overwhelmed, especially in low- and middle-income countries, affecting entire hospital services downstream (Ortiz 2013). The mortality associated with critical care admission due to severe influenza was high (14\% to 22\%) (Jain 2009; Richard 2012).

Current antiviral treatment options for influenza are limited to the neuraminidase inhibitors (NI) and adamantanes, although widespread adamantane use has been hampered by the global emergence of drug resistance (Deyde 2007). A Cochrane Review of randomised placebo-controlled trials (RCTs) reported a reduced time to first alleviation of symptoms by 0.6 to 0.7 days in NI-treated adults, but no differences were seen between the two groups with regard to hospitalisation rates or occurrence of influenza-related adverse events (Jefferson 2014). In contrast, an individual patient level meta-analysis of over 29,000 patients with 2009 influenza A H1N1 virus (H1N1pdm09) infection from 78 observational studies across the world found that $\mathrm{NI}$ treatment at any time, in comparison to no treatment, was associated with a $19 \%$ reduction in mortality risk; early treatment (within two days of symptom onset) was associated with a 52\% reduction in mortality risk in comparison to late treatment (Muthuri 2013).

\section{Description of the intervention}

Endogenous corticosteroids are produced principally in the adrenal glands from cholesterol and are regulated by the hypothalamicpituitary-adrenal (HPA) axis (Molenaar 2012); they possess several anti-inflammatory, immunomodulatory, and vascular properties including inhibition of pro-inflammatory cytokines, reduction of leucocyte trafficking, stimulation of apoptosis of T-lymphocytes, maintaining endothelial integrity and vascular permeability and regulation of vascular tone by inhibition of vasodilators (nitrous oxide) and increasing sensitivity to vasopressors (Cain 2017; Coutinho 2011; Kaufmann 2008). These properties form the rationale for testing corticosteroids in sepsis and related conditions.

A systematic review of RCTs investigating sepsis and septic shock reported that in critically ill individuals with sepsis, corticosteroid use probably results in increased 7-day shock reversal and small reductions in ICU and hospital length of stay, and may achieve a small reduction or no reduction in short-term (28- to 31-day) mortality and possibly a small reduction in long-term mortality (Rochwerg 2018). For the treatment of bacterial meningitis, corticosteroids appear to reduce hearing loss and neurological complications (Brouwer 2015), while in tuberculous meningitis, an improvement in survival was reported (Prasad 2016).

With regard to respiratory infections, a recent Cochrane Review of systemic corticosteroid use in community-acquired pneumonia found a reduction in mortality in adults with severe pneumonia, but not in those with non-severe pneumonia (Stern 2017). Time to clinical cure and length of ICU and hospital stay were also decreased in those treated with corticosteroids, as well as a reduction in the number of people developing respiratory failure or shock and complications of pneumonia. There is limited evidence that systemic corticosteroids as adjunctive therapy to antibiotics in people with acute sinusitis may offer modest benefits for shortterm symptom relief (Venekamp 2014). A review found that in children with croup, corticosteroid treatment was associated with improved symptoms at two hours and decreased readmission rates and length of stay (Gates 2018). No benefits were seen in hospital admission rates or length of stay in hospital following systemic or inhaled corticosteroid use in infants and young children with acute viral bronchiolitis (Fernandes 2013).

The role of corticosteroids for the treatment of influenza is highly controversial. While some case series have reported improved outcomes with corticosteroid treatment of severe influenza (Quispe-Laime 2010), other cohort studies have suggested the opposite (Diaz 2012; Liem 2009). Despite the ongoing controversy, $9 \%$ of hospitalised individuals and up to $69 \%$ of critically ill individuals during the 2009 influenza A (H1N1) pandemic were prescribed corticosteroid therapy (Brun-Buisson 2011; Diaz 2012; 
Kumar 2009; Muthuri 2013). The WHO consultation on human influenza A (H5N1) infection reported that $47 \%$ to $70 \%$ of patients received corticosteroids during the 2004 to 2005 outbreak in Southeast Asia (WHO 2005).

\section{How the intervention might work}

Viral replication and production of cytokines through activation of the host innate immune system are central to the pathogenesis of influenza infection (de Jong 2006). Elevated or excessive production of cytokines (hypercytokinaemia) correlates with symptoms and fever in acute influenza (Lee 2011; McClain 2016). Comparisons between patients with mild and severe pandemic influenza have revealed significantly higher levels of cytokines (especially interleukin-6) in the plasma of patients with severe disease (Yu 2011b), and similar findings have been replicated in studies of severe seasonal influenza (Heltzer 2009). A combination of excessive pro-inflammatory cytokine induced inhibition of the HPA axis, substrate (cholesterol) deficiency, structural damage to the adrenal gland due to infarction of haemorrhage and peripheral corticosteroid resistance could lead to absolute or relative corticosteroid insufficiency during critical illness (Annane 2017; Marik 2009). The overall incidence of adrenal insufficiency in people with critical illness is estimated to be around 20\%, and up to $60 \%$ in those with sepsis and septic shock (Marik 2009). Administration of corticosteroids during critical illness, including severe influenza, may attenuate this state of adrenal insufficiency and help maintain homeostasis, and control dysregulation of the immune system.

\section{Why it is important to do this review}

Treatment options for influenza are limited. Corticosteroids may offer an additional therapeutic option; although they are frequently prescribed for severely ill individuals with influenza, there is controversy regarding their benefits and harms. A systematic review of the current evidence would a) highlight the quality of the available evidence and $b$ ) valuably inform current clinical practice and future research needs.

\section{O B J E C T IVES}

To systematically assess the effectiveness and potential adverse effects of corticosteroids as adjunctive therapy in the treatment of influenza, taking into account differences in timing and doses of corticosteroids.

\section{METHODS}

\section{Criteria for considering studies for this review}

\section{Types of studies}

We considered randomised controlled trials (RCTs), quasiexperimental designs, and observational cohort studies of individuals with influenza investigating corticosteroid treatment versus no corticosteroid therapy for inclusion. We excluded studies with case-control designs due to the inability to determine temporal effects of corticosteroids on the development of nonmortality outcomes. We excluded studies with fewer than 10 participants.

\section{Types of participants}

Individuals with:
1. clinically diagnosed influenza or influenza-like illness (defined as fever, cough, symptoms of upper respiratory tract infection (coryza, sore throat), and constitutional symptoms (headache, myalgia) of acute onset); and/or

2. microbiologically confirmed influenza through sampling of the respiratory tract (nasal swabs, throat swabs, or bronchoalveolar lavage).

There were no restrictions on age, influenza subtypes, or study setting.

\section{Types of interventions}

We considered studies investigating corticosteroid treatment versus no corticosteroid treatment for inclusion. There were no restrictions on the doses of corticosteroid or the types of corticosteroid used. We considered corticosteroid administration by oral and intravenous routes.

\section{Types of outcome measures}

\section{Primary outcomes}

1. For studies of hospitalised participants:

a. number of deaths at 30 days following admission (30-day mortality);

b. rate of admission to ICUs.

2. For studies in the community setting:
a. rate of hospitalisation;
b. time to resolution of symptoms;
c. 30-day mortality.

When studies reported mortality as an outcome following adjustment for potential confounders such as disease severity and patient demographics among other variables, this is referred to as 'adjusted mortality'.

\section{Secondary outcomes}

1. For studies of hospitalised participants:

a. hospital readmission rate at 30 days postdischarge;

b. number and nature of adverse events secondary to corticosteroid use, such as incidence of gastrointestinal bleeding, hospital-acquired infections, and metabolic complications (e.g. hyperglycaemia, hypernatraemia);

c. proportion of participants requiring mechanical ventilation;

d. length of stay in hospital.

2. For studies in the community setting:

a. number and nature of adverse events secondary to corticosteroid use, such as incidence of gastrointestinal bleeding, hospital-acquired infections, and metabolic complications (e.g. hyperglycaemia, hypernatraemia).

\section{Search methods for identification of studies}

\section{Electronic searches}

We searched the following electronic databases: the Cochrane Central Register of Controlled Trials (CENTRAL 2018, Issue 9, searched 3 October 2018), which contains the Cochrane Acute Respiratory Infections Group's Specialised Register, MEDLINE (1946 to October week 1, 2018), Embase (1980 to 3 October 2018), CINAHL (Cumulative Index to Nursing and Allied Health Literature) (1981 to 3 October 2018), LILACS (Latin American and Caribbean Health 
Science Information database) (1982 to 3 October 2018), and Web of Science (1985 to 3 October 2018).

The search strategy implemented in CENTRAL and MEDLINE is provided in Appendix 1. We used the Cochrane Highly Sensitive Search Strategy for identifying randomised trials for the initial search in the MEDLINE database (Lefebvre 2011). We then repeated the MEDLINE search, replacing the randomised trial filter with the Scottish Intercollegiate Guidelines Network (SIGN) filter to identify observational studies (SIGN 2011). We combined these two searches to give the search results for MEDLINE. We repeated this process to search Embase (Appendix 2), CINAHL (Appendix 3), LILACS (Appendix 4), and Web of Science (Appendix 5), adapting the filter as needed.

There were no date, publication, or language restrictions.

\section{Searching other resources}

We searched the following clinical trials registries for ongoing clinical trials on 3 October 2018:

1. ISRCTN registry (www.isrctn.com/);

2. World Health Organization International Clinical Trials Registry Platform (WHO ICTRP) (www.who.int/ictrp); and

3. US National Institutes of Health Ongoing Trials Register ClinicalTrials.gov (clinicaltrials.gov/).

We scrutinised the bibliographies of included studies and the last three years of three major infectious diseases conferences (Interscience Conference on Antimicrobial Agents and Chemotherapy (ICAAC), European Society of Clinical Microbiology and Infectious Diseases (ESCMID), and Asia Pacific Society of Infection Control (APSIC)) to identify potentially eligible studies. We also checked the reference lists of included studies for additional potentially eligible articles. Following execution of the search strategy, we contacted four domain experts to ensure relevant studies had been identified (see Acknowledgements).

\section{Data collection and analysis}

\section{Selection of studies}

Two review authors (CR, WSL, and for the 2018 update, CR, LL) independently reviewed all the citations retrieved using the search strategy described above. We selected studies in two stages: analysis of study titles and abstracts in the first stage, followed by analysis of the full text of the articles. Any disagreements at either stage were resolved through discussion with a third review author (JNVT).

\section{Data extraction and management}

Two review authors independently extracted data from each included study. One review author (CR) extracted data from all eligible studies in the original version, and one review author (LL) extracted data for all eligible studies identified for this update using a standardised pro forma that was previously piloted and specifically adapted for this review. The other review authors shared the duplicate data extraction of all included studies. We obtained the following data from studies:

1. characteristics of study (design, setting, country, enrolment period, methodological details including 'Risk of bias' criteria for
RCTs and the Newcastle-Ottawa Scale for non-randomised trials and comparative observational studies);

2. characteristics of participants (inclusion and exclusion criteria, demographics, comorbid illnesses, disease severity, numbers in each group);

3. characteristics of intervention (type of steroid, route of administration, dose, timing of corticosteroid use (early versus late), and duration of treatment, co-interventions administered);

4. outcome measures.

\section{Assessment of risk of bias in included studies}

Two review authors (CR and JLB in the original review; LL plus a second independent data extractor for this update) independently assessed the methodological quality of experimental studies using the Cochrane 'Risk of bias' tool for the following domains (Higgins 2011):

1. adequacy of the method for generating the randomisation sequence;

2. adequacy of the method for allocation concealment;

3. blinding of participants, clinicians, and outcome assessors with regard to the intervention given;

4. incomplete outcome data (participants lost to follow-up in each treatment group and reasons for losses reported);

5. analysis of participants in the groups to which they were originally randomised (intention-to-treat principle);

6. selective outcome reporting (all primary outcomes listed in the study protocol that are relevant to this review were reported);

7. other potential sources of bias.

We used the validated 'star system' of the Newcastle-Ottawa Scale to assess the risk of bias at the outcome level in observational studies for the following three domains (Newcastle-Ottawa Scale 2014):

1. selection of study groups;

2. comparability of groups;

3. ascertainment of outcome.

\section{Measures of treatment effect}

We extracted dichotomous outcome data from individual studies as tabulated data from which risk ratios (RR) or odds ratios (OR) and 95\% confidence intervals (Cl) were estimated. We extracted adjusted outcome measures as ORs or hazard ratios (HRs) with $95 \% \mathrm{Cls}$ and presented these separately in pooled analyses. For normally distributed continuous data, we calculated mean difference (MD) or standardised mean difference (SMD) with corresponding $95 \% \mathrm{Cls}$. We used medians and interquartile ranges for continuous data that were not normally distributed.

\section{Unit of analysis issues}

We considered the individual participant to be the unit of analysis for RCTs. We analysed cluster-RCTs allowing for that level of randomisation.

\section{Dealing with missing data}

We analysed data on an intention-to-treat basis. For dichotomous outcomes, we assessed the effect assuming participants with 
missing data had a poor outcome. We did not use any form of imputation for participants with missing continuous outcome data. We consulted the CONSORT-type flow chart of participants through the study when available (Schulz 2010). If a flow chart was not available, we looked for information in the text of the results to determine whether all participants included in the study had been analysed. In case of ambiguity, we contacted the trial authors for further information.

In the case of missing data relating to results, for example measures of dispersion, we contacted the trial authors of the study to request further information.

\section{Assessment of heterogeneity}

We used the $1^{2}$ statistic to assess heterogeneity across experimental and observational studies. We considered a value greater than $50 \%$ to reflect substantial heterogeneity between the findings of RCTs (as described in the Cochrane Handbook for Systematic Reviews of Interventions) (Higgins 2011). However, due to the inherent biases within the design of observational studies, we considered a value greater than $75 \%$ to reflect substantial heterogeneity for these studies.

\section{Assessment of reporting biases}

Where at least 10 studies were included in the meta-analysis, we assessed funnel plots for publication bias (small-study bias).

\section{Data synthesis}

One review author (CR, and for this update, $\mathrm{LL}$ ) entered data into Review Manager 5 (RevMan 2014), and two review authors (CR and JLB in the original review; and LL plus a second independent data extractor for this update) independently summarised the data. In the case of experimental studies, where the interventions and populations were similar, we used a random-effects model to pool data due to the potential for inherent biases in the studies. We elected only to use the random-effects model to pool data due to the likely differences in the effectiveness of corticosteroids by participant characteristics. We did not use a fixed-effect model to analyse the data because a) there was a clear rationale for choosing the random-effects model, and $b$ ) there was no concern about the influence of small-study effects.

For observational studies, we extracted tabulated data, crude estimates, and adjusted estimates of effect from the studies. We extracted adjusted outcome measures as ORs or HRs with $95 \%$ $\mathrm{Cls}$ and presented these separately in pooled analyses. We used a similar meta-analysis method to pool data from observational studies as described for RCTs. Where data were available, we presented subgroup analyses of adjusted or unadjusted estimates separately (if both types of data were available, we preferred the use of adjusted estimates of effect in order to minimise potential confounding between the treatment groups).

\section{GRADE and 'Summary of findings' table}

We created a 'Summary of findings' table for the primary outcomes of number of deaths at 30 days following admission and rate of admission to ICUs, and for the secondary outcomes of number and nature of adverse events secondary to corticosteroid use (hospital-acquired infections), and proportion of participants requiring mechanical ventilation. All the outcomes summarised were from studies of hospitalised participants. We used the five
GRADE considerations (study limitations, consistency of effect, imprecision, indirectness, and publication bias) to assess the certainty of a body of evidence as it relates to the studies that contribute data to the meta-analyses for the prespecified outcomes (Atkins 2004). We used the methods and recommendations described in Section 8.5 and Chapter 12 of the Cochrane Handbook for Systematic Reviews of Interventions (Higgins 2011), employing GRADEpro GDT software (GRADEpro GDT 2014). We justified all decisions to downgrade or upgrade the certainty using footnotes and made comments to aid the reader's understanding of the review where necessary.

\section{Subgroup analysis and investigation of heterogeneity}

We performed subgroup analyses in the following areas where possible:

1. daily corticosteroid dose (low versus high; in adults low dose is defined as hydrocortisone $\leq 300 \mathrm{mg}$, dexamethasone $\leq 12 \mathrm{mg}$, prednisolone $\leq 75 \mathrm{mg}$, methylprednisolone $\leq 60 \mathrm{mg}$ ) (Annane 2004);

2. timing of corticosteroid use (early versus late; early defined as $<4$ days of onset of symptoms and late $\geq 4$ days) (Annane 2002; Jain 2009; Nguyen-Van-Tam 2010);

3. duration of corticosteroid course (short versus long course; short course defined as $<5$ days and long course $\geq 5$ days) (Annane 2004);

4. adult versus child population (adult defined as $\geq 16$ years);

5. route of administration (intravenous, oral); and

6. seasonal influenza versus pandemic/outbreak influenza.

\section{Sensitivity analysis}

We performed sensitivity analyses to assess the effect of study design on the primary and secondary outcomes using stratification if a sufficient number of studies were available.

\section{RE S U L T S}

\section{Description of studies}

\section{Results of the search}

For the original publication of this review, our search strategy identified 3416 titles, of which 2812 articles were assessed in the first stage of the selection process after de-duplication. Of these, we scrutinised 95 potentially eligible articles, yielding 19 articles for inclusion (Rodrigo 2016). For this 2018 update we identified a further 981 titles from the electronic searches and 15 through searching other resources (Figure 1). After deduplication, two review authors (CR, LL) independently assessed the additional 874 titles and abstracts retrieved and the full text of the 31 studies deemed potentially eligible. We excluded a previously included study, Diaz 2012, as it had been superceded by a more extensive analysis that included the same participants (Moreno 2018). Of the 30 studies included in the review, we included 21 observational studies in the meta-analysis of mortality (Balaganesakumar 2013; Brun-Buisson 2011; Cao 2016; Chawla 2013; Delaney 2016; Huang 2017; Kim 2011; Kinikar 2012; Lee 2015; Li 2012; Li 2017; Liem 2009; Linko 2011; Mady 2012; Moreno 2018; Patel 2013; Sertogullarindan 2011; Sheu 2017; Viasus 2011; Xi 2010; Yu 2011a). We did not combine data from the one RCT, Wirz 2016, with those from the observational studies. We included the remaining eight articles in the narrative synthesis only, as four 
studies investigated corticosteroid therapy prior to the diagnosis of influenza (Boudreault 2011; Delgado-Rodriguez 2012; Ono 2016; Wu 2012), and four studies reported outcomes other than mortality according to corticosteroid use (Al-Busaidi 2016; Han 2011; Jain 2009; Kudo 2012). 
Figure 1. Study flow diagram for the 2018 update search. We included 12 new studies in the update and excluded 1 study in the original version of the review (Diaz 2012), as it had been superceded by a more recent analysis.

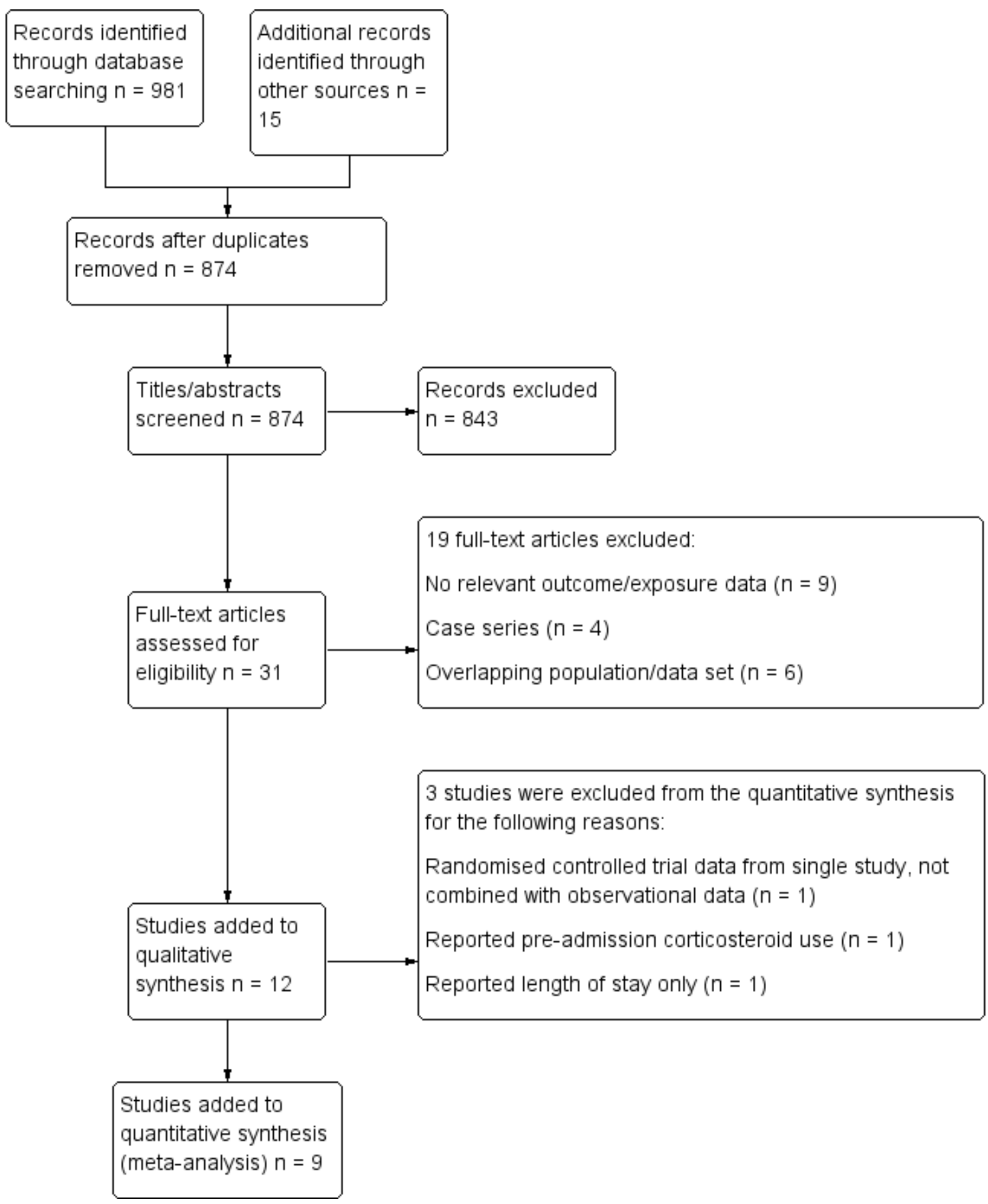




\section{Included studies}

The study design, participant, intervention, and outcome characteristics of the included studies are summarised in the Characteristics of included studies table and Table 1. All studies had an observational design apart from one RCT of prednisone for community-acquired pneumonia, which included a subgroup analysis by pathogen (Wirz 2016). Outcome data according to corticosteroid use were reported for a total of 99,224 participants. All studies were conducted, at least in part, within a hospital setting: nine studies consisted only of individuals admitted to the ICU ( $\mathrm{n}=$ 2934); 19 studies investigated admissions to both ICUs and hospital wards ( $n=95,941)$; one study included individuals from non-ICU wards only $(n=143)$; and one study investigated both outpatients and inpatients $(n=206)$. The viral aetiology of individuals included in the studies was as follows: 20 studies of 2009 influenza A H1N1 virus (H1N1pdm09) $(n=5707)$; seven studies of seasonal influenza ( $n=91,316)$; one study of mixed pandemic and seasonal influenza ( $n=1846)$; one study of influenza A (H5N1) ( $n=38)$; and one study of influenza A (H7N9) $(n=288)$.

The median age of the cohort or corticosteroid treatment groups was reported in 19 studies (varying from 2.5 to 63 years). Of nine studies reporting disease severity according to corticosteroid treatment, adults receiving corticosteroid therapy had higher disease severity scores in comparison to their respective comparator groups in five studies $(n=4530)$ (Kim 2011; Li 2017; Linko 2011; Moreno 2018; Viasus 2011), while the remaining four studies reported no difference in disease severity scores between the two groups ( $n=1356$ ) (Table 1) (Brun-Buisson 2011; Delaney 2016; Han 2011; Mady 2012).

In all studies, comparisons were made between participants treated with or without corticosteroids in addition to supportive treatment, including antiviral agents. Thirteen studies reported the doses or regimens of corticosteroid administered; in eight studies, the mean/median dose of corticosteroid therapy varied between $56.8 \mathrm{mg}$ and $117.5 \mathrm{mg}$ of prednisolone equivalent per day (BrunBuisson 2011; Cao 2016; Delaney 2016; Kim 2011; Li 2017; Linko 2011; Moreno 2018; Xi 2010); four studies reported daily regimens of methylprednisolone 1 to $6 \mathrm{mg} / \mathrm{kg}$ (equivalent to 1.25 to $7.5 \mathrm{mg} /$ kg) (Table 1) (Kudo 2012; Liem 2009; Mady 2012; Patel 2013); and one study reported a daily dose of oral prednisolone of $50 \mathrm{mg} /$ day (Wirz 2016). Seven studies reported the median duration of corticosteroid therapy, which varied from 5.1 to 11.0 days.

\section{Excluded studies}

The main reason for exclusion of 96 articles was lack of data comparing corticosteroid use versus no corticosteroid use. We reported 30 of these studies that might plausibly have been expected to have been included in the review and their respective reasons for exclusion in the Characteristics of excluded studies table.

\section{Risk of bias in included studies}

We used the Cochrane 'Risk of bias' tool to assess the risk of bias in the one RCT, and used the Newcastle-Ottawa Scale for the remaining included studies, all of which were observational.

\section{Cochrane 'Risk of bias' tool for randomised controlled trial}

We judged the randomisation method, allocation of concealment, and blinding to be adequate and at low risk of bias in the one included RCT (Wirz 2016). We could not exclude the presence of other sources of bias, as there were baseline differences between people receiving the treatment and those receiving placebo, and there was under-representation of the sickest people and those in ICU. Also, systematic testing for respiratory viruses did not start until two years into the study, and there were only a small number of participants with laboratory-confirmed influenza included in the subgroup analysis.

\section{Newcastle-Ottawa Scale for observational studies}

The risk of bias for 46 reported outcomes from 30 observational studies included in the review is summarised in Table 2.

\section{Selection of study groups}

The 'selection' domain scored moderately well across studies, and we awarded a maximum score of 4 stars to 28 of the 46 reported outcomes from the following studies: Cao 2016 (mortality, hospital-acquired infection, viral shedding); Delaney 2016 (mortality, ICU-acquired infection); Jain 2009 (ICU admission/ death versus survival/no ICU admission); Kim 2011 (mortality, mechanical ventilation, length of stay, and hospital-acquired infection); Kudo 2012 (length of stay); Lee 2015 (mortality, hospital-acquired infection, length of stay); Li 2017 (mortality, ICU admission, hospital-acquired infection, mechanical ventilation); Liem 2009 (in-hospital mortality); Linko 2011 (in-hospital mortality, length of stay, mechanical ventilation); Moreno 2018 (ICU mortality, length of ICU stay, mechanical ventilation); Viasus 2011 (in-hospital mortality, hospital-acquired infection); and Wu 2012 (influenza requiring hospitalisation). A further 11 of the 46 outcomes were awarded 3 stars. We gave the lowest score of two stars for the 'selection' domain to the following studies: Balaganesakumar 2013 (mortality); Boudreault 2011 (time to death); Huang 2017 (mortality); Li 2012 (mortality); Ono 2016 (hospitalisation); Patel 2013 (mortality); and Yu 2011a (mortality).

\section{Comparability of study groups}

The 'comparability' domain performed the poorest across all the studies in the risk of bias assessment. We awarded a maximum of two stars to the following studies and their respective outcomes: Brun-Buisson 2011 (in-hospital mortality); Cao 2016 (mortality, hospital-acquired infection, viral shedding); Delaney 2016 (mortality); Delgado-Rodriguez 2012 (composite outcome of ICU admission and mortality); Han 2011 (critical illness); Kim 2011 (mortality); Lee 2015 (mortality, length of stay); Li 2017 (mortality); Linko 2011 (in-hospital mortality); Moreno 2018 (ICU mortality); and Ono 2016 (length of stay). The majority of the remaining studies failed to score any stars for this domain. Confounding by indication is a major concern in the included studies, with a high degree of correlation noted between corticosteroid treatment and potential confounders such as disease severity and the presence of comorbid conditions in several studies (Delaney 2016; Kim 2011; Li 2017; Linko 2011; Viasus 2011).

\section{Ascertainment of outcome}

The 'outcome' domain performed the best across all studies, with 35 of the 46 outcomes achieving a maximum score of 3 stars; 23 of the remaining outcomes scored 2 stars, and 1 achieved 1 star (Yu 2011 (mortality)). 


\section{Effects of interventions}

See: Summary of findings for the main comparison Corticosteroid therapy compared to no corticosteroid therapy in the treatment of influenza

Nineteen studies of 2009 influenza A H1N1 virus (H1N1pdm09) reported no difference in or greater adverse outcomes associated with corticosteroid use. One study of people with influenza A virus (H1N1pdm09) pneumonia found that corticosteroids without consideration of dose did not influence mortality, although on subgroup analysis, low to moderate dose corticosteroids, defined as 25 to $150 \mathrm{mg}$ /day of methylprednisolone or its equivalent, were associated with reduced mortality at 30 and 60 days in people with hypoxia, but that there was no beneficial effect with high-dose corticosteroids (Li 2017) The single study of influenza A/H5N1 found that corticosteroid therapy was associated with increased mortality following adjustment for neutropenia as a marker of disease severity (Liem 2009). The study of influenza A/H7N9 found no overall association between corticosteroid treatment and 30-day mortality, although on subgroup analysis there was an association with increased mortality and prolonged viral shedding (Cao 2016). Six studies of individuals with seasonal influenza failed to find any benefits associated with corticosteroid therapy (Boudreault 2011; Huang 2017; Lee 2015; Sheu 2017; Wirz 2016; Wu 2012). The inclusion criteria in these studies included any influenzarelated hospital admission or ICU admission, severe respiratory failure (adult respiratory distress syndrome (ARDS) or requiring mechanical ventilation), septic shock, multi-organ failure, or "critical illness". However, it was not clear why some participants within these cohorts received systemic corticosteroid therapy while others did not. In particular, whether corticosteroid therapy was initiated primarily for treatment of unstable comorbid illnesses (including asthma and chronic obstructive pulmonary disease (COPD)) was not apparent. One study of mixed influenza subtypes that specifically excluded individuals treated with corticosteroids for causes other than viral pneumonia found an association between corticosteroid use and increased ICU mortality (Moreno 2018).

\section{Primary outcomes}

\section{Studies of hospitalised participants}

1. Number of deaths at 30 days following admission (30-day mortality)

We did not include the one RCT in the pooled analyses of observational studies (Wirz 2016); of those participants with laboratory-confirmed influenza, there were two deaths, one in the corticosteroid-treated arm $(n=11)$ and one in the placebo arm ( $n$ $=13$ ). The primary outcome for which this RCT was powered was time to clinical stability rather than mortality, and there were only 24 people in total with laboratory-confirmed influenza.

Due to heterogeneity among studies reporting timing of mortality from hospital admission, stratification by 30-day mortality was not possible as stated in the protocol (Table 3). We graded the certainty of the evidence specific to mortality as very low (Summary of findings for the main comparison) (Guyatt 2011). Meta-analysis of 15 studies ( $n=2212$ participants) revealed a significant increase in the odds of mortality with corticosteroid use, with moderate statistical heterogeneity (odds ratio (OR) 3.90, 95\% confidence interval (Cl) 2.31 to $6.60 ; I^{2}=68 \%$; Analysis 1.1; Figure 2). Subgroup analysis of unadjusted and adjusted OR estimates of mortality showed a similar association with corticosteroid therapy (OR 4.79, $95 \% \mathrm{Cl} 2.35$ to $9.79 ; 1^{2}=67 \%$; Analysis 1.1 .1 and OR $2.23,95 \%$ $\mathrm{Cl} 1.54$ to 3.24 ; Analysis $1.1 .2 ; \mathrm{I}^{2}=0 \%$, respectively). Six studies reported adjusted hazard ratios (HRs) for mortality associated with corticosteroid therapy, with a pooled adjusted HR estimate of 1.49, $95 \% \mathrm{Cl} 1.09$ to $2.02 ; 1^{2}=69 \%$; Analysis 1.2; Figure 3. Four of the studies reported harm (Brun-Buisson 2011; Lee 2015; Moreno 2018; Sheu 2017), while one other study found no association (Li 2017). The remaining study found no association 30 days after admission (HR 1.81, 95\% Cl 0.88 to 3.74) (Cao 2016), although corticosteroid use was associated with mortality at 60 days (HR $1.98,95 \% \mathrm{Cl} 1.03$ to 3.79 ).

Figure 2. Forest plot of comparison: 1 Corticosteroid therapy versus no corticosteroid therapy, Outcome: 1.1 Death following admission, hospitalised participants - mortality - studies reporting odds ratios.

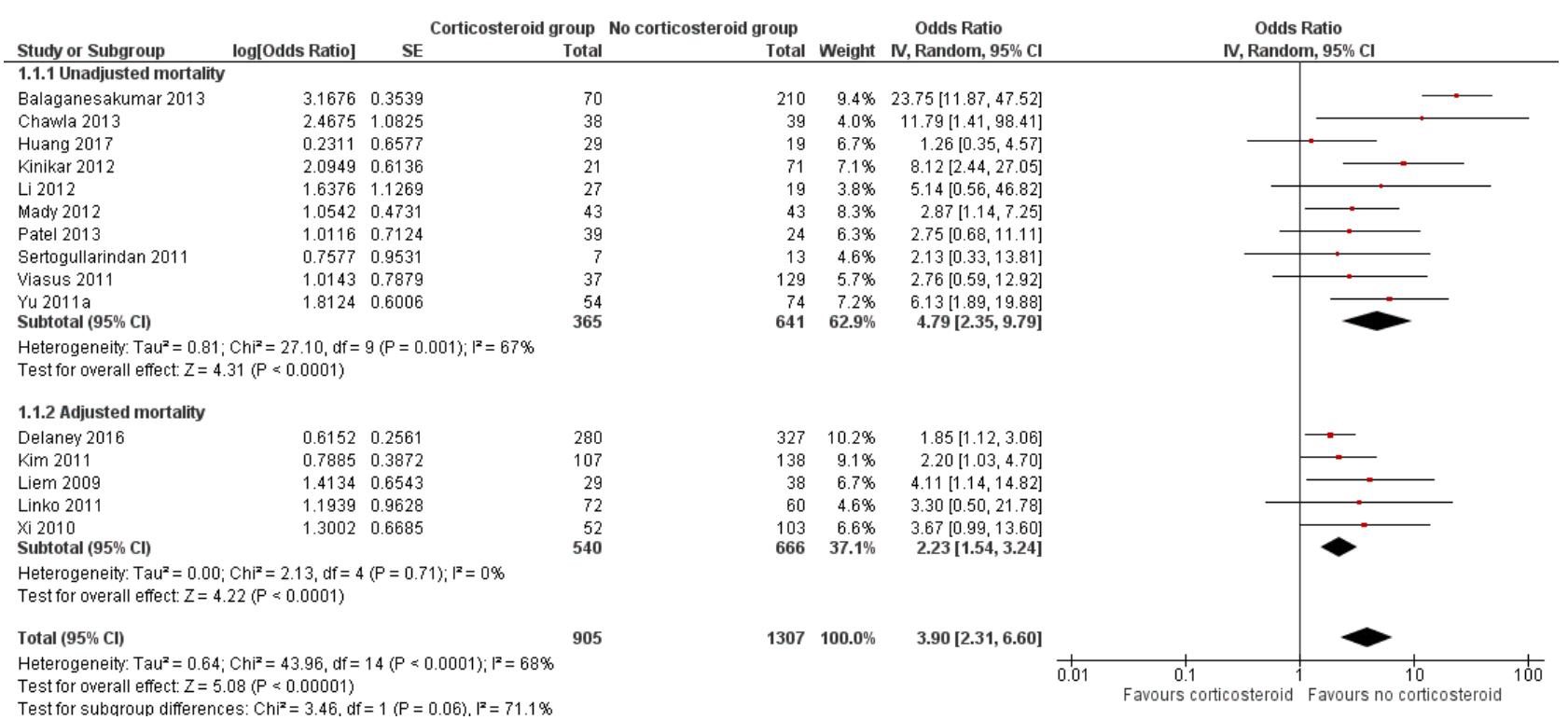


Figure 3. Forest plot of comparison: 1 Corticosteroid therapy versus no corticosteroid therapy, Outcome: 1.2 Death following admission, hospitalised participants - mortality - studies reporting hazard ratios.

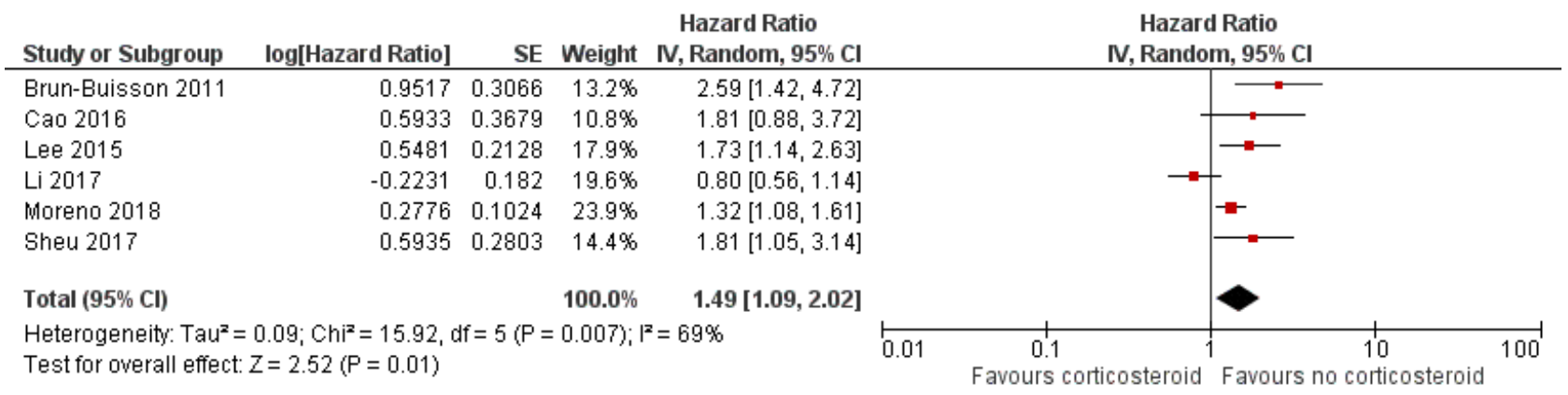

The test for subgroup differences between adjusted and unadjusted mortality was not statistically significant $(P=0.06)$. There was no

Figure 4. Funnel plot of studies reporting mortality.

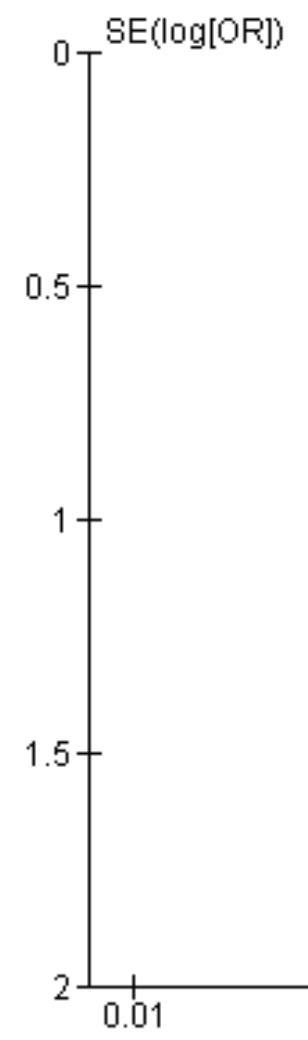

clear indication of publication bias on funnel plot analysis (Figure 4).

Subgroups

Unadjusted mortality $\diamond$ Adjusted mortality

\section{Sensitivity analysis}

Pooled analysis of 15 studies investigating individuals with 2009 influenza A H1N1 virus (H1N1pdm09) infection only, excluding two studies of seasonal influenza and influenza A/H5N1 (Huang 2017; Liem 2009), found corticosteroid use to be associated with greater odds of mortality (OR 4.25, 95\% Cl 2.37 to 7.59 with high statistical heterogeneity $\left.\left(1^{2}=71 \%\right)\right)$.

\section{Subgroup analysis}

A summary of outcomes according to the different corticosteroid regimens is shown in Table 4; the number of studies was insufficient 
to perform subgroup analyses according to the various reported regimens. Three studies categorised corticosteroid dose as low/ low-to-moderate and high dose. One study compared low (defined as $\leq 80 \mathrm{mg} /$ day methylprednisolone or equivalent) versus high doses of corticosteroid treatment (Xi 2010), with no difference in mortality risk $(9 / 30$ versus $8 / 22, P=0.854)$. A retrospective cohort study of people with influenza A H7N9 in China stratified outcomes according to dose and reported that compared to controls, mortality in people receiving high-dose corticosteroids (defined as $>150 \mathrm{mg} /$ day of methylprednisolone or equivalent) was significantly greater (adjusted HR $3.05,95 \% \mathrm{Cl} 1.28$ to 7.25 ; P = 0.012 ), whereas in those participants treated with low to moderate doses of corticosteroids, the risk was not significantly different (HR 1.64, $95 \% \mathrm{Cl} 0.79$ to 3.39; $\mathrm{P}=0.183$ ) (Cao 2016). A further large retrospective Chinese cohort study of 2141 people with influenza A H1N1 virus (H1N1pdm09) suggested that overall, corticosteroids had no effect on mortality (adjusted HR $0.80,95 \% \mathrm{Cl} 0.56$ to 1.15 ) (Li 2017). However, when participants were stratified according to disease severity as measured by their hypoxic status, low- to moderate-dose corticosteroids (defined as 25 to $150 \mathrm{mg} /$ day of methylprednisolone equivalent) were associated with decreased risk of mortality in hypoxic people (ratio of partial pressure of oxygen in arterial blood to inspired fraction of oxygen $\left(\mathrm{PaO}_{2} / \mathrm{FiO}_{2}\right)<$ $300 \mathrm{mmHg}$ ), whereas high-dose corticosteroids showed no benefit in this group (adjusted HR $0.49,95 \% \mathrm{Cl} 0.32$ to $0.77 ; \mathrm{P}=0.02$ and adjusted HR $0.88,95 \% \mathrm{Cl} 0.56$ to $1.39 ; \mathrm{P}=0.581$, respectively). In non-hypoxic people $\left(\mathrm{PaO}_{2} / \mathrm{FiO}_{2} \geq 300 \mathrm{mmHg}\right)$, neither lowto moderate-dose nor high-dose corticosteroids had a significant effect on 30-day mortality (adjusted HR 3.09, 95\% Cl 0.95 to 10.12 ; $\mathrm{P}=0.062$ and adjusted HR $1.70,95 \% \mathrm{Cl} 0.23$ to $12.65 ; \mathrm{P}=0.605$, respectively), although low- to moderate-dose corticosteroids were associated with greater mortality at 60 days (adjusted HR 3.70, 95\% $\mathrm{Cl} 1.20$ to $11.34 ; \mathrm{P}=0.002$ ).

Two studies compared early versus later/no corticosteroid treatment; one defined early treatment as within three days of mechanical ventilation (Brun-Buisson 2011), and the other as within three days from the onset of symptoms (Han 2011). Outcomes stratified according to age group (children versus adults) and route of corticosteroid administration (intravenous versus oral) were not reported in the studies included in this review.

\section{Rate of admission to intensive care units}

Studies reporting outcomes other than mortality are summarised in Table 5. Of the studies that were not conducted entirely in an ICU setting $(n=21)$, two studies reported composite outcomes including ICU admission ("critical disease"), which were stratified according to corticosteroid therapy (Han 2011; Jain 2009). A retrospective cohort study in the USA of individuals hospitalised with 2009 influenza A H1N1 virus (H1N1pdm09) infection reported a greater risk of critical care admission/death (unadjusted OR $2.37,95 \% \mathrm{Cl} 1.29$ to 4.37 ) associated with corticosteroid therapy (Jain 2009). In the other retrospective cohort study from China, the risk of critical disease (defined as death, respiratory failure, septic shock, failure or insufficiency of $\geq 2$ non-pulmonary organs, mechanical ventilation, or ICU admission) adjusted for comorbid illness, obesity, and pregnancy was greater in the group treated with corticosteroid therapy (adjusted risk ratio (RR) $2.4,95 \% \mathrm{Cl}$ 1.3 to 4.4) (Han 2011). Two further studies presented data on ICU admission (Li 2017; Wirz 2016). In the first study, an RCT, no increased risk of ICU admission was seen on subgroup analysis of people with community-acquired pneumonia due to confirmed seasonal influenza (unadjusted OR $1.2,95 \% \mathrm{Cl} 0.07$ to 21.72), although the number of people with confirmed influenza in each study arm was small (Wirz 2016). In the second study, a large retrospective cohort study from mainland China, there was an increased risk of ICU admission in people admitted with 2009 influenza A H1N1 viral pneumonia and treated with corticosteroids (unadjusted OR 5.13, 95\% Cl 4.26 to 6.17) (Li 2017). We graded the certainty of the evidence specific for ICU admission as very low (Summary of findings for the main comparison).

\section{Studies in the community setting}

We did not identify any studies conducted entirely in a community setting.

\section{Rate of hospitalisation}

None of the included studies reported this outcome stratified according to corticosteroid use.

\section{Time to resolution of symptoms}

None of the included studies reported this outcome stratified according to corticosteroid use.

\section{30-day mortality}

None of the included studies reported this outcome stratified according to corticosteroid use.

\section{Secondary outcomes \\ Studies of hospitalised participants}

\section{Hospital readmission rate at 30 days postdischarge}

One study, an RCT of oral corticosteroid versus placebo in people with community-acquired pneumonia, did not show a significant difference in readmission rates between the small numbers of influenza-confirmed people in the two groups, with one readmission in both the corticosteroids-treated arm $(n=11)$ and the placebo arm ( $n=13)$ (Wirz 2016).

\section{Number and nature of adverse events secondary to corticosteroid use, such as incidence of gastrointestinal bleeding, hospital-acquired infections, and metabolic complications (e.g. hyperglycaemia, hypernatraemia)}

A summary of studies reporting hospital-acquired infections according to corticosteroid use is shown in Table 6. Seven studies presented data on the association between corticosteroid treatment and hospital-acquired infection. In four of these studies, corticosteroid use was associated with an increased risk of developing a hospital-acquired infection (Kim 2011; Lee 2015; Li 2017; Viasus 2011), while the remaining three studies did not show significantly increased unadjusted odds of developing infection (Brun-Buisson 2011; Cao 2016; Delaney 2016). Overall, people treated with corticosteroids had greater odds of developing secondary infection than those who did not receive corticosteroids on pooled analysis (unadjusted OR $2.74,95 \% \mathrm{Cl} 1.51$ to $4.95 ; \mathrm{I}^{2}=$ 90\%; 6114 participants; 7 studies; Analysis 1.3; Figure 5). However, there was a very high degree of statistical heterogeneity $(12=90 \%)$, and we graded the certainty of the evidence related to hospitalacquired infection as very low (Summary of findings for the main comparison). 
Figure 5. Forest plot of comparison: 1 Corticosteroid therapy versus no corticosteroid therapy, Outcome: 1.3 Hospital-acquired infection in hospitalised participants.

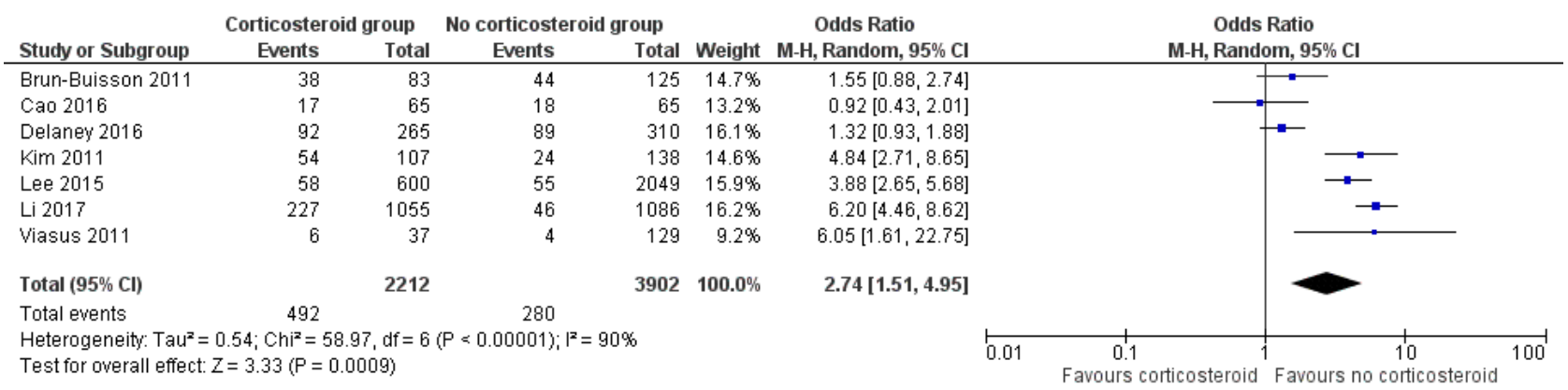

\section{Proportion of participants requiring mechanical ventilation}

Four studies reported greater unadjusted odds for mechanical ventilation in the group treated with corticosteroid therapy, with unadjusted ORs ranging from $1.78(95 \% \mathrm{Cl} 1.35$ to 2.35$)$ to 11.29 (95\% Cl 8.25 to 15.44) (Table 5) (Kim 2011; Li 2017; Linko 2011; Moreno 2018). We graded the certainty of the evidence for mechanical ventilation as very low (Summary of findings for the main comparison).

\section{Length of stay in hospital}

Seven studies reported length of stay according to corticosteroid use; all but one study, Al-Busaidi 2016, were unadjusted for disease severity (Table 5). Four studies found a longer length of stay associated with corticosteroid use (Al-Busaidi 2016; Kim 2011; Lee 2015; Linko 2011), while the other studies reported no statistically significant difference between groups (Brun-Buisson 2011; Kudo 2012; Moreno 2018).

One study analysed the mean time to effective hospital discharge in people with laboratory-confirmed influenza community-acquired pneumonia treated with corticosteroid versus those receiving placebo, finding no significant difference between groups (adjusted difference -2.24 days, $95 \% \mathrm{Cl}-9.61$ to 5.12) (Wirz 2016).

\section{Studies in the community setting}

\section{Number and nature of adverse events secondary to corticosteroid} use

None of the included studies reported this outcome stratified according to corticosteroid use.

\section{Impact of systemic corticosteroid use prior to the diagnosis of influenza}

A study of corticosteroid use for the treatment of graft versus host disease in haematopoietic stem cell transplant recipients, in the two weeks prior to the diagnosis of seasonal influenza, found no observed differences in time to death between individuals receiving low-dose corticosteroid therapy $(<1 \mathrm{mg} / \mathrm{kg} /$ day of methylprednisolone) (adjusted HR 1.1, 95\% Cl 0.4 to 3.6) and highdose corticosteroid therapy ( $\geq 1 \mathrm{mg} / \mathrm{kg} /$ day of methylprednisolone) (adjusted HR $1.1,95 \% \mathrm{Cl} 0.3$ to 3.5 ), in comparison to no prior corticosteroid therapy (Boudreault 2011). A mixed cohort of outpatients and inpatients with seasonal influenza reported increased odds of "complicated influenza" (defined as the need for hospitalisation due to pneumonia, neurological complications, invasive bacterial infection, myocarditis, or pericarditis) associated with corticosteroid therapy (adjusted OR $12.19,95 \% \mathrm{Cl} 3.26$ to 45.53) (Wu 2012). Corticosteroid therapy in the 90 days prior to hospital admission was independently associated with poor outcome (defined as a composite outcome of ICU admission and death) (adjusted $\mathrm{OR} 3.37,95 \% \mathrm{Cl} 1.39$ to 8.20 ) in a study of individuals hospitalised with 2009 influenza A H1N1 virus (H1N1pdm09) infection (Delgado-Rodriguez 2012). A retrospective database study of people under 65 years with confirmed seasonal influenza found that regular oral steroid use for at least 30 days during a 6-month baseline period prior to diagnosis was independently associated with hospitalisation for influenza (adjusted HR 2.35, 95\% Cl 1.12 to 4.91) compared to no prior steroid use (Ono 2016).

\section{DISCUSSION}

\section{Summary of main results}

In the first publication of this review we did not identify any RCTs reporting the impact of adjunctive corticosteroids therapy on clinical outcomes in people with influenza, and the available evidence from observational studies was of very low quality, suggesting that corticosteroid therapy might be associated with up to three-fold greater odds of mortality. We included an additional 12 studies in this 2018 update. One of the additional studies was an RCT, but the inclusion of this study has not affected our overall conclusions, as it was not powered for mortality, our primary outcome of interest, and had only a very small number of participants with laboratory-confirmed influenza in both the treatment and placebo arms. The remaining additional studies were all observational in design, and their inclusion in the metaanalyses still suggests an overall increased risk of mortality with corticosteroid treatment. Two of the more recent studies indicate that the risk may be related to corticosteroid dose, one suggesting that high-dose corticosteroids may be associated with a greater risk than low- to moderate-dose corticosteroids, and the other indicating that low to moderate doses may be beneficial in hypoxic patients only, whereas high-dose corticosteroids may be of no benefit. However, the overall certainty of the evidence remains very low, and these results should be interpreted with caution.

\section{Overall completeness and applicability of evidence}

The findings of this review must be viewed in light of two important considerations. Firstly, the indications for corticosteroid therapy were not fully specified in many studies. In some instances, the 
stated rationale was adult respiratory distress syndrome (ARDS) and septic shock (Brun-Buisson 2011; Kim 2011; Xi 2010). However, at one extreme, corticosteroid therapy may have been used as 'a last attempt' in individuals with refractory illness. Conversely, they may have been used to treat less severe underlying comorbid illnesses such as exacerbations of asthma. Many of studies included in this review relate to the 2009 pandemic, when revised guidance from the World Health Organization in February 2010 would have applied (WHO 2010). However, adherence to that guidance, which recommended that "patients who have severe or progressive clinical illness, including viral pneumonitis, respiratory failure and ARDS due to influenza virus infection, should not be given systemic corticosteroids unless indicated for other reasons or as part of an approved research protocol" is not known. Over the same period, the 'Surviving Sepsis Campaign' recommended the use of corticosteroid therapy only in the setting of vasopressor-dependent septic shock (Dellinger 2013). These guidelines were updated in 2016, maintaining the weak recommendation based on low-quality evidence against the use of corticosteroids to treat septic shock in patients if adequate fluid resuscitation and vasopressor therapy are able to restore haemodynamic stability (Rhodes 2017). A more recently developed clinical practice guideline triggered by the publication of the results of two large clinical trials makes a weak recommendation for corticosteroids in people with sepsis, stating that "both steroids and no steroids are reasonable management options" (Lamontagne 2018). The use of corticosteroids in the context of influenza infection, but for different clinical indications (notably asthma), has been previously shown to be associated with different outcomes (Myles 2013); this may reflect both the different mechanisms of action of corticosteroids depending on the underlying pathophysiology and the impact of bias by indication in reports from observational studies. This is compounded by the lack of consistent adjustment for disease severity across available studies.

The second consideration relates to the doses of corticosteroids used. These were poorly specified in many instances and, where reported, a higher daily dose was used (prednisolone equivalent > $50 \mathrm{mg}$ daily) than is typically recommended for the treatment of septic shock or exacerbations of airways disease such as asthma (BTS 2016; NICE 2010; Rhodes 2017). Variability in corticosteroid dose and administration schedule are both factors associated with treatment outcomes in the setting of severe sepsis; in particular, high doses given in short bursts have not been associated with benefit compared to low doses given for longer durations ( $\geq 5$ days) (Annane 2015). A more recent subgroup analysis failed to identify credible effect modification with corticosteroid dose, although most studies used hydrocortisone with or without fludrocortisone at a low dose $(<400 \mathrm{mg} /$ day of hydrocortisone equivalent) and over a long duration ( $>2$ days) (Rochwerg 2018). The use of higher doses of corticosteroids may explain the greater risk from secondary bacterial pneumonias due to Staphylococcus aureus,Klebsiella pneumoniae,Acinetobacter baumannii,and Pseudomonas aeruginosa observed with corticosteroid therapy in some studies (Kim 2011; Li 2017). In another study, corticosteroid use was also found to be an independent risk factor for the development of invasive fungal infections in adults admitted to the ICU with influenza (Wauters 2012).

The mechanisms behind potential harm from corticosteroids, aside from the risks from hospital-acquired infections, are not well defined. In one study included in this review, prolonged viral shedding as assessed by real-time reverse transcriptionpolymerase chain reaction (RT-PCR) was noted in those treated with high-dose corticosteroids compared to those who did not receive corticosteroids (Cao 2016). In people with influenza $A$ (H3N2) infection, systemic corticosteroid use for exacerbations of asthma or chronic obstructive pulmonary disease was found to be associated with delayed viral clearance (Lee 2009). A study of individuals hospitalised with 2009 influenza A H1N1 virus (H1N1pdm09) infection found that corticosteroid therapy was associated with persistent viral shedding (defined as the detection of virus on RT-PCR at day 7 after diagnosis on nasopharyngeal swabs) (Giannella 2011). A similar observation was made in haematopoietic stem cell transplant recipients with 2009 influenza A H1N1 virus (H1N1pdm09) infection (Choi 2011). In turn, slower clearance of viral load was associated with mortality from ARDS in people with 2009 influenza A H1N1 virus (H1N1pdm09) infection (To 2010). Though causation cannot be inferred from these studies, exposure to systemic corticosteroids without concurrent antiviral treatment, as was likely for some participants in the studies reviewed, may proffer the highest risk of harm (Jain 2009; Wu 2012).

There was no evidence of publication bias in the effect of corticosteroids on the odds of mortality, where we found that the treatment effects in smaller studies were similar to those estimated in the larger studies. Although the test was likely to have sufficient power from including 15 studies in the funnel plot, we acknowledge their limitation of being subjective.

\section{Quality of the evidence}

The pooled analysis of mortality showed high statistical heterogeneity, most likely due to the inclusion of unadjusted estimates of mortality. Clinical heterogeneity was apparent across the included studies. Specifically, disease severity was measured using a wide variety of clinical risk scores, and mortality was reported at different time points; the rationale for corticosteroid use was inconsistent across studies; there was variation in the treatment groups with regard to the timing, dosage, duration, and type of corticosteroid used; and the co-interventions for the comparator groups across studies were not uniform, as varying proportions of adults were treated with antivirals or antibiotics, or both. We graded the overall certainty of the evidence for mortality, adverse events, rate of mechanical ventilation, and critical disease as very low due to the high likelihood of indication bias, and clinical and statistical heterogeneity among the included observational studies (Summary of findings for the main comparison).

\section{Potential biases in the review process}

The identified evidence consists solely of observational data apart from one RCT that included only a very small subset of people with laboratory-confirmed influenza, and in which the primary outcome measure was time to clinical stability, rather than mortality, and so was not powered for our main outcome of interest. We noted a high degree of correlation between corticosteroid therapy and potential confounders for measured outcomes (such as disease severity and the presence of comorbid illness) in some studies (Delaney 2016; Kim 2011; Li 2017; Linko 2011; Viasus 2011), hence unadjusted effect estimates are likely to be confounded by indication. 


\section{Agreements and disagreements with other studies or reviews}

Two systematic reviews and meta-analyses have been published since the original version of this review (Yang 2015b; Zhang 2015). As in this review, they both found an apparently increased risk of mortality in people with influenza treated with corticosteroids, however all the data were observational and likely to be biased by indication, and the authors concluded that the evidence did not support the use of corticosteroids as standard care for people with severe influenza (Zhang 2015), and that physicians should use caution when considering corticosteroid treatment in people with influenza infection (Yang 2015b). Zhang 2015 searched only for studies relating to influenza A H1N1 pdm2009 published in English or Chinese but also included case-control studies, which we decided to exclude due to the inability to determine temporal effects of corticosteroids on the development of non-mortality outcomes. The authors reported a risk ratio (RR) for mortality of $1.85(95 \% \mathrm{Cl} 1.46$ to 2.33$)$ from 9 cohort studies ( $n=1405)$, and 4.22 $(95 \% \mathrm{Cl} 3.10$ to 5.76$)$ from 14 case-control studies $(n=4700)$. Yang 2015b searched for relevant studies of any influenza subtype and included 19 studies in their meta-analysis, finding an association between corticosteroid treatment and mortality (unadjusted OR $1.98,95 \% \mathrm{Cl} 1.62$ to 2.43 ; $\mathrm{I}^{2}=9 \%$; adjusted OR $1.77,95 \% \mathrm{Cl} 1.40$ to $\left.2.23,1^{2}=40 \%\right)$. The authors also reported an increased risk of hospital-acquired infection with corticosteroid use (OR $3.16,95 \% \mathrm{Cl}$ 2.09 to $4.78 ; 12=54 \%$ ), which is in accordance with our findings on meta-analysis (OR $2.74,95 \% \mathrm{Cl} 1.51$ to 4.95 ), although we reported a higher level of statistical heterogeneity $\left(1^{2}=90 \%\right)$. Although there was overlap in the included studies between this review and the other reviews, our review included several studies that were not included in one or both of the other reviews (Balaganesakumar 2013; Boudreault 2011; Delgado-Rodriguez 2012; Han 2011; Jain 2009; Kim 2011; Li 2012; Liem 2009; Linko 2011; Mady 2012; Patel 2013; Sertogullarindan 2011; Wu 2012). Two studies included in Zhang 2015 that were not included in our original review met our inclusion criteria were added to this 2018 update (Kinikar 2012; Yu 2011a).

We did not include a large, multicentre prospective cohort study of 220 individuals admitted to ICUs across Europe with 2009 influenza A H1N1 virus (H1N1pdm09) infection in this review due to overlapping study populations; this study found no association between corticosteroid use and ICU admission and ICU mortality after adjustment for age, comorbid illnesses, and disease severity (adjusted HR 1.3, 95\% Cl 0.7 to 2.4; P = 0.4) (Martin-Loeches 2011).

The association between increased mortality odds and adjunctive corticosteroid therapy as found in this review is also in contrast to the evidence base from clinical trials of corticosteroids in the setting of sepsis and pneumonia. Specifically, a meta-analysis of 42 RCTs $(n=10,194)$ of corticosteroids in severe sepsis concluded that corticosteroids may achieve a small reduction or no reduction in the RR for dying in the short term ( 28 to 31 days) (RR 0.93, $95 \% \mathrm{Cl} 0.84$ to 1.03 ), with a possible small decrease in longerterm mortality ( 60 days to 1 year) (RR $0.94,95 \% \mathrm{Cl} 0.89$ to 1.00 ) (Rochwerg 2018). This most recent systematic review included the results of two recent large RCTs, the Activated Protein $C$ and Corticosteroids for Human Septic Shock (APROCCHSS) trial ( $n=$ 1241) and the Adjunctive Glucocorticoid Therapy in Patients with Septic Shock trial ( $n=3800)$ (Annane 2018; Venkatesh 2018). A metaanalysis of 12 RCTs $(n=1974)$ of adults with community-acquired pneumonia concluded that adjunctive corticosteroid therapy may reduce mortality, the need for mechanical ventilation, and hospital length of stay (Siemieniuk 2015). Decreased mortality with adjuvant corticosteroid treatment was also found in adults with severe community-acquired pneumonia, but not in those with non-severe pneumonia, in a meta-analysis of 17 RCTs with 2264 participants; time to clinical cure, length of hospital stay, and the development of respiratory failure or shock were also decreased (Stern 2017).

Other recent meta-analyses have also noted an association between adjuvant corticosteroid therapy and decreased mortality in a subset of people with severe community-acquired pneumonia, as well as decreased length of hospital stay and decreased time to clinical stability (Bi 2016 (8 RCTs; $n=528$ ); Horita 2015 (10 RCTs; $\mathrm{n}=1780$ ); Marti 2015 (14 RCTs; $\mathrm{n}=2077$ ); and Wu 2018 (10 RCTs; $\mathrm{n}=729)$ ). Two further systematic reviews and meta-analyses did not find an effect of adjuvant corticosteroids on mortality, either overall or in severely ill cases, but both reported decreased length of hospital stay (Chen 2015 (7 RCTs; $\mathrm{n}=$ 944); Wan 2016 (9 RCTs; $n=1667$ and 6 cohort studies; $n=4095)$ ). One of the reviews also found that corticosteroid therapy was associated with a decreased risk of ARDS and may reduce the duration of intravenous antibiotic therapy and time to clinical stability (Wan 2016). Larger trials of corticosteroid therapy in severe pneumonia are in progress and should provide more robust data within the next few years (NCT01743755; NCT02517489).

\section{AUTHORS' CONCLUSIONS}

\section{Implications for practice}

The available evidence from this updated review is from observational studies and one randomised controlled trial of limited relevance and remains, as in the original review, of very lowquality with confounding by indication a major potential concern. There is insufficient evidence in this updated review to determine the effectiveness of corticosteroids for people with influenza. There is a need for more robust evidence on the role of corticosteroids in the management of influenza before a firm recommendation for clinical practice can be made.

\section{Implications for research}

The most important need is for high-quality, blinded randomised controlled trials, which will minimise the biases inherent in observational designs and thereby provide the necessary evidence base to inform future clinical practice. Future observational studies investigating corticosteroids for the treatment of influenza should state the precise rationale for the administration of corticosteroid therapy in study participants (such as treatment of complications of influenza, comorbid illness, or use solely as adjunctive therapy). The regimens of corticosteroid therapy should be explicitly stated with regard to the dose, timing of initiation, and duration of therapy, and differences in regimens need to be considered when interpreting the results of studies. Differences in the administration of co-interventions between corticosteroid-treated and untreated groups, including antiviral drugs and antibiotics, also need to be accounted for. Outcome measures need to be adjusted for potential confounders including imbalances in baseline characteristics and disease severity at the very least. A meta-analysis of individual patient level data from observational studies may be able to overcome some of the inconsistencies across study-level data. 


\section{ACK N OWLEDGEMENTS}

We are grateful to the following individuals for commenting on the draft protocol: Vinod Singh, Noorin Bhimani, Harri Hemilä, Rashmi Das, Sree Nair, and Lubna Al-Ansary; and for commenting on the draft review: Jenny Negus, Marco Confalonieri, Rashmi
Das, Conor Teljeur, and Lubna Al-Ansary. We wish to thank the following domain experts for ensuring that we have identified pertinent studies in our literature search: Frederick Hayden, David Hui, Nelson Lee, and Djillali Annane. For this update we would like to thank Vadsala Baskaran, Sara Belazi, Hannah Lawrence, and Harry Pick for their help with data extraction. 


\section{R E F E R E N C E S}

\section{References to studies included in this review}

\section{Al-Busaidi 2016 \{published data only\}}

Al-Busaidi M, Al Maamari K, Al'Adawi B, Ba Alawi F, Al-Wahaibi A, Belkhair A. Pandemic influenza a H1N1 in Oman: epidemiology, clinical features, and outcome of patients admitted to Sultan Qaboos University Hospital in 2009. Oman Medical Journal 2016;31(4):290-7.

\section{Balaganesakumar 2013 \{published data only\}}

Balaganesakumar SR, Murhekar MV, Swamy KK, Kumar MR, Manickam P, Pandian P. Risk factors associated with death among influenza A (H1N1) patients, Tamil Nadu, India, 2010. Journal of Postgraduate Medicine 2013;59(1):9-14.

\section{Boudreault 2011 \{published data only\}}

* Boudreault A, Xie H, Leisenring W, Englund J, Corey L, Boeckh M. Impact of corticosteroid treatment and antiviral therapy on clinical outcomes in hematopoietic cell transplant patients infected with influenza virus. Biology of Blood and Marrow Transplantation 2011;17(7):979-86.

Brun-Buisson 2011 \{published data only\}

* Brun-Buisson C, Jean-Christophe M, Mercat A, Thiebaut A, Brochard L. Early corticosteroids in severe influenza A/ H1N1 pneumonia and acute respiratory distress syndrome. American Journal of Respiratory and Critical Care Medicine 2011;183(9):1200-6.

\section{Cao 2016 \{published data only\}}

Cao B, Gao H, Zhou BP, Deng XL, Hu CP, Deng CS, et al. Adjuvant corticosteroid treatment in adults with influenza $A(\mathrm{H} 7 \mathrm{~N} 9)$ viral pneumonia. Critical Care Medicine 2016;44(6):E318-28.

\section{Chawla 2013 \{published data only\}}

Chawla R, Kansal S, Chauhan M, Jain A, Jibhkate B. Predictors of mortality and length of stay in hospitalized cases of 2009 influenza A (H1N1): experiences of a tertiary care center. Indian Journal of Critical Care Medicine 2013;17(5):275-82.

\section{Delaney 2016 \{published data only\}}

Delaney JW, Pinto R, Long J, Lamontagne F, Adhikari NK, Kumar A, et al. The influence of corticosteroid treatment on the outcome of influenza A (H1N1pdm09)-related critical illness. Critical Care 2016;20(75):1-11. [DOI: 10.1186/s13054-016-1230-8]

\section{Delgado-Rodriguez 2012 \{published data only\}}

Delgado-Rodriguez M, Castilla J, Godoy P, Martin V, Soldevila N, Alonso J, et al. Prognosis of hospitalized patients with 2009 H1N1 influenza in Spain: influence of neuraminidase inhibitors. Journal of Antimicrobial Chemotherapy 2012;67(7):1739-45.

\section{Han 2011 \{published data only\}}

Han K, Ma H, An X, Su Y, Chen J, Lian Z, et al. Early use of glucocorticoids was a risk factor for critical disease and death from pH1N1 infection. Clinical Infectious Diseases 2011;53(4):326-33.
Huang 2017 \{published data only\}

Huang SF, Fung CP, Perng DW, Wang FD. Effects of corticosteroid and neuraminidase inhibitors on survival in patients with respiratory distress induced by influenza virus. Journal of Microbiology, Immunology and Infection 2017;50(5):586-94.

\section{Jain 2009 \{published data only\}}

Jain S, Kamimoto L, Bramley A, Schmitz A, Benoit S, Louie J, et al. Hospitalized patients with $2009 \mathrm{H} 1 \mathrm{~N} 1$ influenza in the United States, April-June 2009. New England Journal of Medicine 2009;361(20):1935-44

\section{Kim 2011 \{published data only\}}

Kim S, Hong S, Yun S, Choi W, Ahn J, Lee Y, et al. Corticosteroid treatment in critically ill patients with pandemic influenza $\mathrm{A} /$ H1N1 2009 infection: analytic strategy using propensity scores. American Journal of Respiratory and Critical Care Medicine 2011;183(9):1207-14.

\section{Kinikar 2012 \{published data only\}}

Kinikar AA, Kulkarni RK, Valvi CT, Mave V, Gupte N, Khadse S, et al. Predictors of mortality in hospitalized children with pandemic H1N1 influenza 2009 in Pune, India. Indian Journal of Pediatrics 2012;79(4):459-66.

\section{Kudo 2012 \{published data only\}}

Kudo K, Takasaki J, Manabe T, Uryu H, Yamada R, Kuroda E, et al. Systemic corticosteroids and early administration of antiviral agents for pneumonia with acute wheezing due to influenza $A$ (H1N1) pdm09 in Japan. PLOS ONE 2012;7(2):e32280.

Lee 2015 \{published data only\} Lee N, Leo YS, Cao B, Chan PK, Kyaw WM, Uyeki TM, et al. Neuraminidase inhibitors, superinfection and corticosteroids affect survival of influenza patients. European Respiratory Journal 2015;45(6):1642-52

\section{Li 2012 \{published data only\}}

Li F, Chen G, Wang J, Liu H, Wu J. A case-control study on risk factors associated with death in pregnant women with severe pandemic H1N1 infection. BMJ Open 2012;2(4):e000827.

\section{Li 2017 \{published data only\}}

Li H, Yang SG, Gu L, Zhang Y, Yan XX, Liang ZA, et al. Effect of low-to-moderate-dose corticosteroids on mortality of hospitalized adolescents and adults with influenza A (H1N1) pdm09 viral pneumonia. Influenza and Other Respiratory Viruses 2017;11(4):345-54.

\section{Liem 2009 \{published data only\}}

Liem N, Tung C, Hien N, Hien T, Chau N, Long H, et al. Clinical features of human influenza A (H5N1) infection in Vietnam: 2004-2006. Clinical Infectious Diseases 2009;48(12):1639-46.

\section{Linko 2011 \{published data only\}}

Linko R, Pettila V, Ruokonen E, Varpula T, Karlsson S, Tenhunen J, et al. Corticosteroid therapy in intensive care unit patients with PCR-confirmed influenza A (H1N1) infection in Finland. Acta Anaesthesiologica Scandinavica 2011;55(8):971-9. 
Mady 2012 \{published data only\}

Mady A, Ramadan O, Yousef A, Mandourah Y, Amr A, Kherallah M. Clinical experience with severe $2009 \mathrm{H} 1 \mathrm{~N} 1$ influenza in the intensive care unit at King Saud Medical City, Saudi Arabia. Journal of Infection and Public Health 2012;5(1):52-6.

\section{Moreno 2018 \{published data only\}}

Moreno G, Rodriguez A, Reyes LF, Gomez J, Sole-Violan J, Diaz E, et al. Corticosteroid treatment in critically ill patients with severe influenza pneumonia: a propensity score matching study. Intensive Care Medicine 2018;44(9):1470-82.

Ono 2016 \{published data only\}

Ono S, Ono Y, Matsui H, Yasunaga H. Factors associated with hospitalization for seasonal influenza in a Japanese nonelderly cohort. BMC Public Health 2016;16:922.

\section{Patel 2013 \{published data only\}}

Patel K, Patel A, Mehta P, Amin R, Patel K, Chuhan P, et al. Clinical outcome of novel H1N1 (swine flu)-infected patients during 2009 pandemic at tertiary referral hospital in western India. Journal of Global Infectious Diseases 2013;5(3):93-7.

\section{Sertogullarindan 2011 \{published data only\}}

Sertogullarindan B, Ozbay B, Gunini H, Sunnetcioglu A, Arisoy A, Bilgin $\mathrm{HM}$, et al. Clinical and prognostic features of patients with pandemic 2009 influenza a (H1N1) virus in the intensive care unit. African Health Sciences 2011;11(2):163-70.

\section{Sheu 2017 \{published data only\}}

Sheu C-C, Chang W-A, Tsai M-J, Tsai J-R, Chong I-W. Early corticosteroid treatment in patients with influenza-associated acute respiratory distress syndrome. American Journal of Respiratory and Critical Care Medicine 2017;195:A2769. [A2769]

Viasus 2011 \{published data only\}

Viasus D, Pano-Pardo J, Cordero E, Campins A, LopezMedrano F, Villoslada A, et al. Effect of immunomodulatory therapies in patients with pandemic influenza $A(H 1 N 1)$ 2009 complicated by pneumonia. Journal of Infection 2011;62(3):193-9.

\section{Wirz 2016 \{published data only\}}

Wirz SA, Blum CA, Schuetz P, Albrich WC, Noppen C, Mueller B, et al. Pathogen- and antibiotic-specific effects of prednisone in community-acquired pneumonia. European Respiratory Journal 2016;48(4):1150-9.

\section{Wu 2012 \{published data only\}}

Wu U, Wang J, Ho Y, Pan S, Chen Y, Chang S. Factors associated with development of complications among adults with influenza: a 3-year prospective analysis. Journal of the Formosan Medical Association 2012;111(7):364-9.

\section{Xi 2010 \{published data only\}}

Xi X, Xu Y, Jiang L, Li A, Duan J, Du B, et al. Hospitalized adult patients with 2009 influenza A (H1N1) in Beijing, China: risk factors for hospital mortality. BMC Infectious Diseases 2010;10:256.

\section{Yu 2011a \{published data only\}}

Yu H-T, Yang Y-J, Zhang Q-X, Jia J-G, Chen Q-S, Zang J-P, et al. Clinical characteristics and risk factors of severe patients with novel pandemic influenza A H1N1. Chinese Journal of Integrated Traditional and Western Medicine in Intensive and Critical Care 2011;18(3):142-5.

\section{References to studies excluded from this review}

Chan 2014 \{published data only\}

Chan W, Chang K, Loung P, Lai C, Tse W. Serious pandemic influenza $\mathrm{A} / \mathrm{H} 1 \mathrm{~N} 1$ infection in paediatric intensive care unit from 2009-2014. Hong Kong Journal of Paediatrics 2014;19:199-200.

Chen 2010 \{published data only\}

Chen K, Li YJ, Li KZ, Wu ZX, Ning B, Lu LJ. Glucocorticoid treatment on severe A/H1N1 influenza. Chinese Journal of Nosocomiology 2010;20:3149-51.

Chien 2010 \{published data only\}

Chien YS, Su CP, Tsai HT, Huang AS, Lien CE, Hung MN, et al. Predictors and outcomes of respiratory failure among hospitalized pneumonia patients with $2009 \mathrm{H} 1 \mathrm{~N} 1$ influenza in Taiwan. Journal of Infection 2010;60(2):168-74.

\section{Chotpitayasunondh 2005 \{published data only\}}

Chotpitayasunondh T, Ungchusak K, Hanshaoworakul W, Chunsuthiwat S, Sawanpanyalert P, Kijphati R, et al. Human disease from influenza A (H5N1), Thailand, 2004. Emerging Infectious Diseases 2005;11(2):201-9.

\section{Diaz 2012 \{published data only\}}

Diaz E, Martin-Loeches I, Canadell L, Vidaur L, Suarez D, Socias $L$, et al. Corticosteroid therapy in patients with primary viral pneumonia due to pandemic (H1N1) 2009 influenza. Journal of Infection 2012;64(3):311-8.

\section{Dominguez-Cherit 2016 \{published data only\}}

Dominguez-Cherit G, De la Torre A, Rishu A, Pinto R, ÑamendysSilva SA, Camacho-Ortiz A, et al. Influenza A (H1N1pdm09)related critical illness and mortality in Mexico and Canada, 2014. Critical Care Medicine 2016;44(10):1861-70.

\section{Fujikura 2014 \{published data only\}}

Fujikura Y, Kawano S, Kouzaki Y, Shinoda M, Hara Y, Shinkai M, et al. The (H1N1) 2009 pandemic influenza pneumonia among adult patients in Japan. Japanese Journal of Infectious Diseases 2014;67(2):100-4

\section{Gao 2013 \{published data only\}}

Gao H, Lu H, Cao B, Du B, Shang H, Gan J, et al. Clinical findings in 111 cases of influenza $A$ (H7N9) virus infection. New England Journal of Medicine 2013;368(24):2277-85.

\section{Garnacho-Montero 2013 \{published data only\}}

Garnacho-Montero J, Gutierrez-Pizarraya A, Marquez J, Zaragoza R, Granada R, Ruiz-Santana S, et al. Epidemiology, clinical features, and prognosis of elderly adults with severe forms of influenza A (H1N1). Journal of the American Geriatrics Society 2013;61(3):350-6. 
Hien 2009 \{published data only\}

Hien ND, Ha NH, Van NT, Ha NT, Lien TT, Thai NQ, et al. Human infection with highly pathogenic avian influenza virus (H5N1) in northern Vietnam, 2004-2005. Emerging Infectious Diseases 2009;15(1):19-23.

\section{Hong 2013 \{published data only\}}

Hong SB, Choi EY, Kim SH, Suh GY, Park MS, Lee MG, et al. Epidemiological analysis of critically ill adult patients with pandemic influenza $\mathrm{A}(\mathrm{H} 1 \mathrm{~N} 1)$ in South Korea. Epidemiology and Infection 2013;141(5):1070-9.

\section{Hu 2013 \{published data only\}}

Hu Y, Lu S, Song Z, Wang W, Hao P, Li J, et al. Association between adverse clinical outcome in human disease caused by novel influenza A H7N9 virus and sustained viral shedding and emergence of antiviral resistance. Lancet 2013;381(9885):2273-9.

\section{Jung 2011 \{published data only\}}

Jung JY, Park BH, Hong SB, Koh Y, Suh GY, Jeon K, et al. Acute kidney injury in critically ill patients with pandemic influenza A pneumonia 2009 in Korea: a multicenter study. Journal of Critical Care 2011;26(6):577-85.

\section{Leon 2017 \{published data only\}}

Leon Moya C, Gutierrez Pizarraya A, Canton Bulnes ML, Arenzana Seisdedos A, Rodriguez A, Garnacho-Montero J. Characteristics of immunocompromised patients with influenza $A$ virus admitted to the intensive care unit. Intensive Care Medicine Experimental 2017;5(Suppl 2):1027.

\section{Martin-Loeches 2013 \{published data only\}}

Martin-Loeches I, Bermejo-Martin J, Valles J, Granada R, Vidaur L, Vergara-Serrano J, et al. Macrolide-based regimens in absence of bacterial co-infection in critically ill H1N1 patients with primary viral pneumonia. Intensive Care Medicine 2013;39(4):693-702.

\section{McKenna 2013 \{published data only\}}

McKenna J, Bramley A, Skarbinski J, Fry A, Finelli L, Jain S. Asthma in patients hospitalized with pandemic influenza A (H1N1) pdm09 virus infection - United States, 2009. BMC Infectious Diseases 2013;13:57.

\section{Ning 2014 \{published data only\}}

Ning J. Diagnosis and treatment of children with severe influenza A from the 2009/2010 pandemic in Tianjin, China. Tropical Doctor 2014;44(2):69-70.

\section{Okur 2013 \{published data only\}}

Okur M, Erbey F, Yazicioglu O, Celik A, Tukenmez B, Sunnetcioglu M. H1N1 influenza A virus related pneumonia and respiratory failure. Indian Journal of Virology 2013;24(1):85-9.

\section{Perez-Padilla 2009 \{published data only\}}

Perez-Padilla R, de la Rosa-Zamboni D, Ponce de Leon S, Hernandez M, Quinones-Falconi F, Bautista E, et al. Pneumonia and respiratory failure from swine-origin influenza $A(\mathrm{H} 1 \mathrm{~N} 1)$ in Mexico. New England Journal of Medicine 2009;361(7):680-9.

\section{Rios 2011 \{published data only\}}

Rios FG, Estenssoro E, Villarejo F, Valentini R, Aguilar L, Pezzola D, et al. Lung function and organ dysfunctions in 178 patients requiring mechanical ventilation during the 2009 influenza A (H1N1) pandemic. Critical Care 2011;15(4):R201.

\section{Segaloff 2017 \{published data only\}}

Segaloff HE, Evans R, Arshad S, Zervos MJ, Archer C, Kaye KS, et al. The impact of obesity and timely antiviral administration on severe influenza outcomes among hospitalized adults. Journal of Medical Virology 2018;90(2):212-8.

\section{Singh 2017 \{published data only\}}

Singh A, Khera K, Agarwal J, Awasthi S, Francis JM, Thunga G, et al. Descriptive analysis of mortality predictors in $\mathrm{H} 1 \mathrm{n} 1$ influenza in south Indian patients. Infectious Disorders - Drug Targets 2017;17(2):106-15.

\section{Smud 2010 \{published data only\}}

Smud A, Nagel C, Madsen E, Rial M, Barcan L, Gomez A, et al. Pandemic influenza a/H1N1 virus infection in solid organ transplant recipients: a multicenter study. Transplantation 2010;90(12):400.

\section{Sun 2010 \{published data only\}}

Sun JJ, Li C, Wu DW, Li CH, Qin WH, Li YL, et al. Eighteen cases of 2009 influenza A H1N1 associated with respiratory failure in adults. Zhongguo Wei Zhong Bing Ji Jiu Yi Xue [Chinese Critical Care Medicine] 2010;22(3):156-60.

\section{Torres 2012 \{published data only\}}

Torres SF, lolster T, Schnitzler EJ, Farias JA, Bordogna AC, Rufach D, et al. High mortality in patients with influenza A pH1N1 2009 admitted to a pediatric intensive care unit: a predictive model of mortality. Pediatric Critical Care Medicine 2012;13(2):e78-83.

\section{Vilar-Compte 2018 \{published data only\}}

Vilar-Compte D, Shah DP, Vanichanan J, Cornejo-Juarez P, Garcia-Horton A, Volkow P, et al. Influenza in patients with hematological malignancies: experience at two comprehensive cancer centers. Journal of Medical Virology 2018;90(1):50-60.

\section{Yale 2015 \{published data only\}}

Yale P, Adhikari NK, Masse V, Fowler RA, Xiong W, McGeer A, et al. Corticosteroid therapy in critical illness due to seasonal and pandemic influenza. Canadian Respiratory Journal 2015;22(5):271-4.

\section{Yang 2015a \{published data only\}}

Yang Y, Guo F, Zhao W, Gu Q, Huang M, Cao Q, et al. Novel avianorigin influenza a (H7N9) in critically ill patients in China. Critical Care Medicine 2015;43(2):339-45.

Zhang 2011 \{published data only\}

Zhang X-D, Chen W-W, Yin X-G, Zhang C, Li R, Li G-M, et al. Retrospective analysis of 146 severe or critically ill patients with influenza A H1N1. Journal of Kunming Medical University 2011:4:136-41. 
Zhang 2013 \{published data only\}

Zhang PJ, Cao B, Li XL, Liang LR, Yang SG, Gu L, et al. Risk factors for adult death due to 2009 pandemic influenza $A$ (H1N1) virus infection: a 2151 severe and critical cases analysis. Chinese Medical Journal 2013;126(12):2222-8.

\section{Additional references}

\section{Annane 2002}

Annane D, Sebille V, Charpentier C, Bollaert PE, Francois B, Korach JM, et al. Effect of treatment with low doses of hydrocortisone and fludrocortisone on mortality in patients with septic shock. JAMA 2002;288(7):862-71. [PUBMED: 12186604]

Annane 2004

Annane D, Bellissant E, Bollaert P, Briegel J, Keh D, Kupfer Y. Corticosteroids for severe sepsis and septic shock: a systematic review and meta-analysis. BMJ 2004;329(7464):480. [DOI: 10.1136/bmj.38181.482222.55]

\section{Annane 2015}

Annane D, Bellissant E, Bollaert PE, Briegel J, Keh D, Kupfer Y. Corticosteroids for treating sepsis. Cochrane Database of Systematic Reviews 2015, Issue 12. [DOI: 10.1002/14651858.CD002243.pub3]

\section{Annane 2017}

Annane D, Pastores SM, Arlt W, Balk RA, Beishuizen A, Briegel J, et al. Critical illness-related corticosteroid insufficiency (CIRCI): a narrative review from a Multispecialty Task Force of the Society of Critical Care Medicine (SCCM) and the European Society of Intensive Care Medicine (ESICM). Intensive Care Medicine 2017;43(12):1781-92.

\section{Annane 2018}

Annane D, Renault A, Brun-Buisson C, Megarbane B, Quenot JP, Siami S, et al. Hydrocortisone plus fludrocortisone for adults with septic shock. New England Journal of Medicine 2018;378(9):809-18.

\section{Atkins 2004}

Atkins D, Best D, Briss PA, Eccles M, Falck-Ytter Y, Flottorp S, et al. Grading quality of evidence and strength of recommendations. BMJ (Clinical research ed.) 2004;328(7454):1490. [PUBMED: 15205295]

\section{Bi 2016}

Bi J, Yang J, Wang Y, Yao C, Mei J, Liu Y, et al. Efficacy and safety of adjunctive corticosteroids therapy for severe communityacquired pneumonia in adults: an updated systematic review and meta-analysis. PLOS ONE 2016;11(11):e0165942.

\section{Brouwer 2015}

Brouwer MC, McIntyre P, Prasad K, van de Beek D. Corticosteroids for acute bacterial meningitis. Cochrane Database of Systematic Reviews 2015, Issue 9. [DOI: 10.1002/14651858.CD004405.pub5]

\section{BTS 2016}

British Thoracic Society/Scottish Intercollegiate Guidelines Network. BTS/SIGN British guideline for the management of asthma, 2016, SIGN 153. www.sign.ac.uk/sign-153-britishguideline-on-the-management-of-asthma.html (accessed prior to 12 February 2019).

\section{Cain 2017}

Cain DW, Cidlowski JA. Immune regulation by glucocorticoids. Nature Reviews Immunology 2017;17(4):233-47.

\section{Caini 2016}

Caini S, Andrade W, Badur S, Balmaseda A, Barakat A, Bella A, et al. Temporal patterns of influenza $A$ and $B$ in tropical and temperate countries: what are the lessons for influenza vaccination?. PLOS ONE 2016;11(3):e0152310.

\section{Chen 2015}

Chen LP, Chen JH, Chen Y, Wu C, Yang XH. Efficacy and safety of glucocorticoids in the treatment of community-acquired pneumonia: a meta-analysis of randomized controlled trials. World Journal of Emergency Medicine 2015;6(3):172-8.

\section{Choi 2011}

Choi SM, Boudreault A, Xie H, Englund J, Corey L, Boeckh M. Differences in clinical outcomes after 2009 influenza A/H1N1 and seasonal influenza among hematopoietic cell transplant recipients. Blood 2011;117(19):5050-6.

\section{Coutinho 2011}

Coutinho AE, Chapman KE. The anti-inflammatory and immunosuppressive effects of glucocorticoids, recent developments and mechanistic insights. Molecular and Cellular Endocrinology 2011;335(1):2-13.

\section{Cromer 2014}

Cromer D, van Hoek AJ, Jit M, Edmunds WJ, Fleming D, Miller E. The burden of influenza in England by age and clinical risk group: a statistical analysis to inform vaccine policy. Journal of Infection 2014;68(4):363-71. [PUBMED: 24291062]

\section{Dawood 2012}

Dawood F, luliano A, Reed C, Meltzer M, Shay D, Cheng PY. Estimated global mortality associated with the first 12 months of 2009 pandemic influenza A H1N1 virus circulation: a modelling study. Lancet Infectious Diseases 2012;12(9):687-95.

\section{de Jong 2006}

de Jong MD, Simmons CP, Thanh TT, Hien VM, Smith GJ, Chau TN, et al. Fatal outcome of human influenza A (H5N1) is associated with high viral load and hypercytokinemia. Nature Medicine 2006;12(10):1203-7.

\section{Dellinger 2013}

Dellinger RP, Levy MM, Rhodes A, Annane D, Gerlach H, Opal SM, et al. Surviving Sepsis Campaign: international guidelines for management of severe sepsis and septic shock: 2012. Critical Care Medicine 2013;41(2):580-637. 


\section{Deyde 2007}

Deyde V, Xu X, Bright R, Shaw M, Smith C, Zhang Y. Surveillance of resistance to adamantanes among influenza $A(H 3 N 2)$ and A (H1N1) viruses isolated worldwide. Journal of Infectious Diseases 2007;196(2):249-57.

\section{Donaldson 2010}

Donaldson LJ, Rutter PD, Ellis BM, Greaves FE, Mytton OT, Pebody RG, et al. Mortality from pandemic A/H1N1 2009 influenza in England: public health surveillance study. BMJ 2010;339:b5213. [DOI: 10.1136/bmj.b5213]

\section{Fernandes 2013}

Fernandes RM, Bialy LM, Vandermeer B, Tjosvold L, Plint AC, Patel $\mathrm{H}$, et al. Glucocorticoids for acute viral bronchiolitis in infants and young children. Cochrane Database of Systematic Reviews 2013, Issue 6. [DOI: 10.1002/14651858.CD004878.pub4]

\section{Gates 2018}

Gates A, Gates M, Vandermeer B, Johnson C, Hartling L, Johnson DW. Glucocorticoids for croup in children. Cochrane Database of Systematic Reviews 2018, Issue 8. [DOI: 10.1002/14651858.CD001955.pub4]

\section{Giannella 2011}

Giannella M, Alonso M, Garcia de Viedma D, Lopez Roa P, Catalan $\mathrm{P}$, Padilla $\mathrm{B}$, et al. Prolonged viral shedding in pandemic influenza A (H1N1): clinical significance and viral load analysis in hospitalized patients. Clinical Microbiology \& Infection 2011;17(8):1160-5

\section{GRADEpro GDT 2014 [Computer program]}

McMaster University (developed by Evidence Prime). GRADEpro GDT. Version accessed 22 October 2018. Hamilton (ON): McMaster University (developed by Evidence Prime), 2014.

\section{Guyatt 2011}

Guyatt G, Oxman AD, Akl EA, Kunz R, Vist G, Brozek J, et al. GRADE guidelines: 1 . Introduction - GRADE evidence profiles and summary of findings tables. Journal of Clinical Epidemiology 2011;64(4):383-94.

\section{Heltzer 2009}

Heltzer ML, Coffin SE, Maurer K, Bagashev A, Zhang Z, Orange JS, et al. Immune dysregulation in severe influenza. Journal of Leukocyte Biology 2009;85(6):1036-43.

\section{Higgins 2011}

Higgins JP, Green S (editors). Cochrane Handbook for Systematic Reviews of Interventions Version 5.1.0 [updated March 2011]. The Cochrane Collaboration, 2011. Available from handbook.cochrane.org.

\section{Horita 2015}

Horita N, Otsuka T, Haranaga S, Namkoong H, Miki M, Miyashita N, et al. Adjunctive systemic corticosteroids for hospitalized community-acquired pneumonia: systematic review and meta-analysis 2015 update. Scientific Reports 2015;5:14061.

\section{Iuliano 2018}

Iuliano AD, Roguski KM, Chang HH, Muscatello DJ, Palekar R, Tempia S, et al. Estimates of global seasonal influenzaassociated respiratory mortality: a modelling study. Lancet 2018;391(10127):1285-300

\section{Jefferson 2014}

Jefferson T, Jones M, Doshi P, Del Mar C, Heneghan C, Hama $R$, et al. Neuraminidase inhibitors for preventing and treating influenza in adults and children. Cochrane Database of Systematic Reviews 2014, Issue 4. [DOI: 10.1002/14651858.CD008965.pub4]

\section{Kaufmann 2008}

Kaufmann, Briegel J, Schliephake F, Hoelzl AC, Alexander H, Theresia S, et al. Stress doses of hydrocortisone in septic shock: beneficial effects on opsonization-dependent neutrophil functions. Intensive Care Medicine 2008;34(2):344-9.

\section{Kumar 2009}

Kumar A, Zarychanski R, Pinto R, Cook DJ, Marshall J, Lacroix J. Critically ill patients with 2009 influenza A (H1N1) infection in Canada. JAMA 2009;302(17):1872-9.

\section{Lamontagne 2018}

Lamontagne F, Rochwerg B, Lytvyn L, Guyatt GH, Møller MH, Annane $D$, et al. Corticosteroid therapy for sepsis: a clinical practice guideline. BMJ 2018; Vol. 362:k3284.

\section{Lee 2009}

Lee N, Chan P, Hui D, Rainer T, Wong E, Choi KW, et al. Viral loads and duration of viral shedding in adult patients hospitalized with influenza. Journal of Infectious Diseases 2009;200(4):492-500.

\section{Lee 2011}

Lee N, Wong CK, Chan PK, Chan MC, Wong RY, Lun SW, et al. Cytokine response patterns in severe pandemic $2009 \mathrm{H} 1 \mathrm{~N} 1$ and seasonal influenza among hospitalized adults. PLOS ONE 2011;6(10):e26050.

\section{Lefebvre 2011}

Lefebvre C, Manheimer E, Glanville J. Chapter 6: Searching for studies. In: Higgins JP, Green S (editors). Cochrane Handbook for Systematic Reviews of Interventions Version 5.1.0 [updated March 2011]. The Cochrane Collaboration, 2011. Available from handbook.cochrane.org.

\section{Marik 2009}

Marik PE. Critical illness-related corticosteroid insufficiency. Chest 2009;135(1):181-93.

\section{Marti 2015}

Marti C, Grosgurin O, Harbarth S, Combescure C, Abbas M, Rutschmann $\mathrm{O}$, et al. Adjunctive corticotherapy for community acquired pneumonia: a systematic review and meta-analysis. PLOS ONE 2015;10(12):e0144032.

\section{Martin-Loeches 2011}

Martin-Loeches I, Lisboa T, Rhodes A, Moreno RP, Silva E, Sprung C, et al. Use of early corticosteroid therapy on ICU 
admission in patients affected by severe pandemic ( $\mathrm{H} 1 \mathrm{~N} 1)$ influenza A infection. Intensive Care Medicine 2010;37(2):272-83. [DOI: 10.1007/s00134-010-2078-z]

\section{McClain 2016}

McClain MT, Henao R, Williams J, Nicholson B, Veldman T, Hudson L, et al. Differential evolution of peripheral cytokine levels in symptomatic and asymptomatic responses to experimental influenza virus challenge. Clinical and Experimental Immunology 2016;183(3):441-51.

\section{Molenaar 2012}

Molenaar N, Bijkerk RM, Beishuizen A, Hempen CM, de Jong MF, Vermes I, et al. Steroidogenesis in the adrenal dysfunction of critical illness: impact of etomidate. Critical Care 2012;16(4):1-9.

\section{Muthuri 2013}

Muthuri SG, Myles PR, Venkatesan S, Leonardi-Bee J, NguyenVan-Tam JS. Impact of neuraminidase inhibitor treatment on outcomes of public health importance during the 2009-2010 influenza A (H1N1) pandemic: a systematic review and metaanalysis in hospitalized patients. Journal of Infectious Diseases 2013;207(4):553-63.

\section{Myles 2013}

Myles P, Nguyen-Van-Tam JS, Semple MG, Brett SJ, Bannister B, Read R, et al. Differences between asthmatics and nonasthmatics hospitalised with influenza $A$ infection. European Respiratory Journal 2013;41(4):824-31.

\section{NCT01743755}

NCT01743755. Santeon-CAP; Dexamethasone in communityacquired pneumonia. clinicaltrials.gov/ct2/show/study/ NCT01743755?term=SANTEON\&rank=1 (first received 22 November 2012).

\section{NCT02517489}

NCT02517489. Community-acquired pneumonia: evaluation of corticosteroids [Effects of low-dose corticosteroids on survival of severe community-acquired pneumonia]. clinicaltrials.gov/ ct2/show/study/NCT02517489?term=CAPE+COD\&rank=3 (first received 31 July 2015).

\section{Newcastle-Ottawa Scale 2014}

Wells GA, Shea B, O'Connell D, Peterson J, Welch V, Losos M, et al. The Newcastle-Ottawa Scale (NOS) for assessing the quality of nonrandomised studies in meta-analyses. www.ohri.ca/ programs/clinical_epidemiology/oxford.asp (accessed prior to 12 February 2019).

\section{Nguyen-Van-Tam 2010}

Nguyen-Van-Tam JS, Openshaw PJ, Hashim A, Gadd EM, Lim WS, Semple MG, et al. Risk factors for hospitalisation and poor outcome with pandemic A/H1N1 influenza: United Kingdom first wave (May-September 2009). Thorax 2010;65(7):645-51. [PUBMED: 20627925]

\section{NICE 2010}

National Institute for Health and Care Excellence. Chronic obstructive pulmonary disease in over 16s: diagnosis and management. www.nice.org.uk/guidance/CG101 June 2010 (accessed prior to 12 February 2019).

\section{Ortiz 2013}

Ortiz JR, Rudd KE, Clark DV, Jacob S, West TE. Clinical research during a public health emergency: a systematic review of severe pandemic influenza management. Critical Care Medicine 2013;41(5):1345-52.

\section{Ortiz 2014}

Ortiz JR, Neuzil KM, Shay DK, Rue TC, Neradilek MB, Zhou H, et al. The burden of influenza-associated critical illness hospitalizations. Critical Care Medicine 2014;42(11):2325-32. [PUBMED: 25148596]

\section{Peasah 2013}

Peasah SK, Azziz-Baumgartner E, Breese J, Meltzer MI, Widdowson MA. Influenza cost and cost-effectiveness studies globally - a review. Vaccine 2013;31(46):5339-48. [PUBMED: 24055351]

\section{Prasad 2016}

Prasad K, Singh MB, Ryan H. Corticosteroids for managing tuberculous meningitis. Cochrane Database of Systematic Reviews 2016, Issue 4. [DOI: 10.1002/14651858.CD002244.pub4]

\section{Quispe-Laime 2010}

Quispe-Laime A, Bracco J, Barberio P, Campagne C, Rolfo V, Umberger R, et al. H1N1 influenza A virus-associated acute lung injury: response to combination oseltamivir and prolonged corticosteroid treatment. Intensive Care Medicine 2010;36(1):33-41.

\section{RevMan 2014 [Computer program]}

Nordic Cochrane Centre, The Cochrane Collaboration. Review Manager 5 (RevMan 5). Version 5.3. Copenhagen: Nordic Cochrane Centre, The Cochrane Collaboration, 2014.

\section{Rhodes 2017}

Rhodes A, Evans LE, Alhazzani W, Levy MM, Antonelli M, Ferrer R, et al. Surviving Sepsis Campaign: International Guidelines for Management of Sepsis and Septic Shock: 2016. Intensive Care Medicine 2017;43(3):304-77.

\section{Richard 2012}

Richard J, Pham T, Brun-Buisson C, Reignier J, Mercat A Beduneau $G$. Interest of a simple on-line screening registry for measuring ICU burden related to an influenza pandemic. Critical Care 2012;16(4):1-10.

\section{Rochwerg 2018}

Rochwerg B, Oczkowski SJ, Siemieniuk RAC, Agoritsas T, BelleyCote E, D'Aragon F, et al. Corticosteroids in sepsis: an updated systematic review and meta-analysis. Critical Care Medicine 2018;46(9):1411-20.

\section{Schulz 2010}

Schulz KF, Altman DG, Moher D. CONSORT 2010 Statement: updated guidelines for reporting parallel group randomised trials. BMJ 2010;340(c332):698-702. [DOI: 10.1136/bmj.c332] 


\section{Siemieniuk 2015}

Siemieniuk RA, Meade MO, Alonso-Coello P, Briel M, Evaniew N, Prasad M, et al. Corticosteroid therapy for patients hospitalized with community-acquired pneumonia: a systematic review and meta-analysis. Annals of Internal Medicine 2015;163(7):519-28. [PUBMED: 26258555]

\section{SIGN 2011}

Scottish Intercollegiate Guidelines Network (SIGN). Search filters, observational studies. www.sign.ac.uk/searchfilters.html (accessed 14 November 2017).

\section{Stern 2017}

Stern A, Skalsky K, Avni T, Carrara E, Leibovici L, Paul M. Corticosteroids for pneumonia. Cochrane Database of Systematic Reviews 2017, Issue 12. [DOI: 10.1002/14651858.CD007720.pub3]

\section{Taubenberger 2008}

Taubenberger J, Morens D. The pathology of influenza virus infections. Annual Review of Pathology: Mechanisms of Disease 2008;3(1):499-522.

\section{To 2010}

To K, Hung I, Li I, Lee K, Koo C, Yan W, et al. Delayed clearance of viral load and marked cytokine activation in severe cases of pandemic H1N1 2009 influenza virus infection. Clinical Infectious Diseases 2010;50(6):850-9.

\section{Venekamp 2014}

Venekamp RP, Thompson MJ, Hayward G, Heneghan CJ, Del Mar CB, Perera R, et al. Systemic corticosteroids for acute sinusitis. Cochrane Database of Systematic Reviews 2014, Issue 3. [DOI: 10.1002/14651858.CD008115.pub3]

\section{Venkatesh 2018}

Venkatesh B, Finfer S, Cohen J, Rajbhandari D, Arabi Y, Bellomo R, et al. Adjunctive glucocorticoid therapy in patients with septic shock. New England Journal of Medicine 2018;378(9):797-808.

\section{Viboud 2010}

Viboud C, Miller M, Olson D, Osterholm M, Simonsen L. Preliminary estimates of mortality and years of life lost associated with the $2009 \mathrm{~A} / \mathrm{H} 1 \mathrm{~N} 1$ pandemic in the US and comparison with past influenza seasons. PLOS Currents 2010;2:RRN1153. [DOI: 10.1371/currents.RRN1153]

\section{Wan 2016}

Wan YD, Sun TW, Liu ZQ, Zhang SG, Wang LX, Kan QC. Efficacy and safety of corticosteroids for community-acquired pneumonia: a systematic review and meta-analysis. Chest 2016;149(1):209-19.

\section{Wauters 2012}

Wauters J, Baar I, Meersseman P, Meersseman W, Dams K, De Paep R, et al. Invasive pulmonary aspergillosis is a frequent complication of critically ill $\mathrm{H} 1 \mathrm{~N} 1$ patients: a retrospective study. Intensive Care Medicine 2012;38(11):1761-8.

\section{WHO 2005}

The Writing Committee of the World Health Organization (WHO) Consultation on Human Influenza A/H5. Avian influenza A (H5N1) infection in humans. New England Journal of Medicine 2005;353(13):1374-85.

\section{WHO 2010}

World Health Organization. WHO guidelines for the pharmacological management of pandemic influenza A(H1N1) 2009 and other influenza viruses. www.who.int/csr/resources/publications/swineflu/ h1n1_guidelines_pharmaceutical_mngt.pdf?ua $=12010$ (accessed prior to 12 February 2019).

\section{WHO 2018}

World Health Organization. Influenza (Seasonal). www.who.int/ news-room/fact-sheets/detail/influenza-(seasonal) (accessed 23 October 2018).

\section{Wu 2018}

Wu WF, Fang Q, He GJ. Efficacy of corticosteroid treatment for severe community-acquired pneumonia: a meta-analysis. American Journal of Emergency Medicine 2018;36(2):179-84.

\section{Yang 2015b}

Yang JW, Fan LC, Miao XY, Mao B, Li MH, Lu HW, et al. Corticosteroids for the treatment of human infection with influenza virus: a systematic review and meta-analysis. Clinical Microbiology and Infection 2015;21(10):956-63.

\section{Yu 2011b}

Yu X, Zhang X, Zhao B, Wang J, Zhu Z, Teng Z, et al. Intensive cytokine induction in pandemic H1N1 influenza virus infection accompanied by robust production of IL-10 and IL-6. PLOS ONE 2011;6(12):e28680. [DOI: 10.1371/journal.pone.0028680]

\section{Zhang 2015}

Zhang Y, Sun WJ, Svendsen ER, Tang S, Maclntyre RC, Yang P, et al. Do corticosteroids reduce the mortality of influenza A (H1N1) infection? A meta-analysis. Critical Care 2015;19(1):46. [DOI: 10.1186/s13054-015-0764-5]

\section{Zhou 2012}

Zhou H, Thompson WW, Viboud CG, Ringholz CM, Cheng PY, Steiner C, et al. Hospitalizations associated with influenza and respiratory syncytial virus in the United States, 1993-2008. Clinical Infectious Diseases 2012;54(10):1427-36. [PUBMED: 22495079]

\section{References to other published versions of this review Rodrigo 2013}

Rodrigo C, Leonardi-Bee J, Nguyen-Van-Tam J, Lim WS. Corticosteroids as adjunctive therapy in the treatment of influenza. Cochrane Database of Systematic Reviews 2013, Issue 2. [DOI: 10.1002/14651858.CD010406]

\section{Rodrigo 2016}

Rodrigo C, Leonardi-Bee J, Nguyen-Van-Tam J, Lim WS. Corticosteroids as adjunctive therapy in the treatment of 
influenza. Cochrane Database of Systematic Reviews 2016, Issue

3. [DOI: 10.1002/14651858.CD010406.pub2]

* Indicates the major publication for the study

\section{CHARACTERISTICS OF STUDIES}

Characteristics of included studies [ordered by study ID]

Al-Busaidi 2016

\begin{tabular}{|c|c|}
\hline Methods & Single-centre retrospective cohort study \\
\hline \multirow[t]{7}{*}{ Participants } & Country: Oman \\
\hline & Setting: in-hospital \\
\hline & Number of individuals: 68 \\
\hline & $\begin{array}{l}\text { Inclusion criteria: all admitted patients (adult and paediatric) with laboratory-confirmed influenza A } \\
(\mathrm{H} 1 \mathrm{~N} 1)\end{array}$ \\
\hline & Influenza type: 2009 influenza A H1N1 virus (H1N1pdm09) \\
\hline & Median age of cohort: 23 years (range 25 days to 67 years) \\
\hline & Female sex: $41(60.3 \%)$ \\
\hline \multirow[t]{2}{*}{ Interventions } & Groups: corticosteroids $(n=11)$ and no corticosteroids $(n=57)$ \\
\hline & No details of dose, duration, or timing of CS. \\
\hline Outcomes & Length of stay: presented as multivariable coefficient (95\% Cl) \\
\hline \multirow{4}{*}{$\begin{array}{l}\text { Risk of bias (Newcastle-Ot- } \\
\text { tawa Scale) }\end{array}$} & Length of stay \\
\hline & Selection domain score $(\max 4): 3$ \\
\hline & Comparability domain score (max 2): 1 (unclear if adjusted for age) \\
\hline & Outcome domain score: 1 \\
\hline Notes & - \\
\hline
\end{tabular}

Balaganesakumar 2013

\begin{tabular}{ll}
\hline Methods & Multicentre prospective cohort study \\
\hline Participants & Country: India (Tamil Nadu) \\
Setting: in-hospital \\
Number of individuals: 1302 (280 included in case-control analysis) \\
Inclusion criteria: individuals with laboratory-confirmed influenza \\
Influenza type: 2009 influenza A H1N1 virus (H1N1pdm09) \\
Median age of cohort (years): 26 (IQR 1 to 82$)$ \\
Female sex: 666 (51\%)
\end{tabular}


Balaganesakumar 2013 (Continued)

Outcomes Mortality

Risk of bias (Newcastle-Ot- Mortality

tawa Scale)

Selection domain score $(\max 4): 2$

Comparability domain score ( $\max 2): 1$ (no adjustment for disease severity)

Outcome domain score $(\max 3): 2$

Notes - -

Boudreault 2011

\begin{tabular}{ll}
\hline Methods & Single-centre retrospective cohort \\
\hline Participants & Country: USA (Washington) \\
Setting: in-hospital & Number of individuals: 143 \\
& Inclusion criteria: individuals undergoing haematopoietic stem cell transplantation presenting with \\
& respiratory tract infections \\
& Definition of influenza: laboratory confirmed \\
& Influenza type: seasonal \\
& Median age (years): cohort 42.0 (IQR 31.0 to 53.0); no CS group 42.0 (IQR 32.0 to 51.0); low-dose CS \\
group 42.0 (IQR 28.0 to 53.0); high-dose CS group 40.0 (IQR 32.0 to 54.0 )
\end{tabular}

Male sex: cohort 83 (58.0); no CS group 36 (57.0); low-dose CS group 29 (67.0); high-dose CS group 18 (49.0)

Interventions $\quad$ Groups: No CS $(n=63)$; low-dose CS $(n=43)$; high-dose CS $(n=37)$

Definitions for dose: low-dose (prednisolone/methylprednisolone $<1 \mathrm{mg} / \mathrm{kg} /$ day); high-dose (prednisolone/methylprednisolone >= $1 \mathrm{mg} / \mathrm{kg} /$ day) (dose considered was the highest dose taken during the 2 weeks preceding the influenza diagnosis)

Co-interventions: antiviral therapy

Outcomes

Time to death/time to influenza-associated death: hazard ratios presented following multivariate analysis. Variables in the multivariate models included CS treatment, antiviral therapy, and lymphocyte count

\section{Hypoxaemia}

\section{Lower respiratory tract disease}

\section{Mechanical ventilation}

Adverse events: prolonged viral shedding

\section{Risk of bias (Newcastle-Ot- Time to death}

tawa Scale)

Selection domain score $(\max 4): 2$

Comparability domain score ( $\max 2): 1$ (no adjustment for age/disease severity) 
Boudreault 2011 (Continued)

Outcome domain score $(\max 3): 2$

\title{
Notes
}

\author{
$-$
}

Brun-Buisson 2011

\begin{tabular}{|c|c|}
\hline Methods & Multicentre retrospective analysis of prospectively collected data \\
\hline \multirow[t]{12}{*}{ Participants } & Country: France (French REVA-SRLF registry) \\
\hline & Setting: ICU \\
\hline & Number of sites: 78 \\
\hline & Number of individuals: 208 \\
\hline & $\begin{array}{l}\text { Inclusion criteria: severe respiratory failure (defined as adult respiratory distress syndrome or need } \\
\text { for mechanical ventilation) }\end{array}$ \\
\hline & $\begin{array}{l}\text { Exclusion criteria: chronic steroid use or steroid use in ICU other than for respiratory failure; patients } \\
\text { receiving CS as rescue therapy (initiated } 2 \text { weeks after commencing mechanical ventilation); admitted } \\
\text { for other decompensated underlying illness }\end{array}$ \\
\hline & Definition of influenza: laboratory confirmed or clinically suspected \\
\hline & Influenza type: 2009 influenza A H1N1 virus (H1N1pdm09) \\
\hline & $\begin{array}{l}\text { Median age (years): cohort } 47.0 \text { (IQR } 35.0 \text { to } 55.0 \text { ); no CS group } 45.0 \text { (IQR } 35.0 \text { to } 55.0 \text { ); CS group } 49.0 \\
\text { (IQR } 34.0 \text { to 56.0) }\end{array}$ \\
\hline & Female sex: cohort 103 (49.5); no CS group 56.0 (44.8); CS group 47 (56.6) \\
\hline & Comorbid illnesses: immunodepression; no CS 23 (18.4); CS 23 (18.4) \\
\hline & $\begin{array}{l}\text { Disease severity: Median Simplified Acute Physiology Score (version 3) (SAPS 3): cohort } 52.0 \text { (IQR } 44.0 \\
\text { to 64.0); no CS group 53.0 (IQR 46.0 to 66.0); CS group 51.0 (IQR } 44.0 \text { to } 61.0 \text { ) (P= } 0.25 \text { for } 2 \text { groups) }\end{array}$ \\
\hline \multirow[t]{4}{*}{ Interventions } & Groups: no CS $(n=125)$ versus CS $(n=83)$ \\
\hline & Median daily dose: $270 \mathrm{mg}$ (IQR 200 to $400 \mathrm{mg}$ ) of hydrocortisone equivalent \\
\hline & Timing of therapy: initiated within median 1 day (IQR 0 to 6 ) of mechanical ventilation \\
\hline & Duration of treatment: median 11 days (IQR 6 to 20 ) \\
\hline
\end{tabular}

Outcomes

Hospital mortality: hazard ratios presented following a) adjustment for immunosuppression, SAPS 3 and vasopressor use in a Cox regression model; and b) propensity score matching

\section{Length of ICU stay}

Adverse events (ICU-acquired infections)

\section{Risk of bias (Newcastle-Ot- In-hospital mortality} tawa Scale)

\author{
Selection domain score $(\max 4): 3$ \\ Comparability domain score $(\max 2): 2$ \\ Outcome domain score $(\max 3): 3$
}

\section{Length of ICU stay}


Brun-Buisson 2011 (Continued)

Selection domain score $(\max 4): 3$

Comparability domain score $(\max 2): 0$

Outcome domain score $(\max 3): 3$

\section{ICU-acquired infection}

Selection domain score $(\max 4): 3$

Comparability domain score $(\max 2): 0$

Outcome domain score $(\max 3): 3$

Methods Multicentre retrospective cohort plus propensity score-matched case-control study

Participants

Country: China (mainland)

Setting: in-hospital

Number of individuals: 288

Inclusion criteria: individuals aged $\geq 14$ years admitted to hospitals throughout China with pneumonia and laboratory-confirmed H7N9 influenza infection. All had radiological evidence of pneumonia.

Exclusion criteria: no data due to being treated outside mainland China, aged under 14 years, incomplete data, physicians declined to participate

Influenza type: $\mathrm{A} / \mathrm{H} 7 \mathrm{~N} 9$

Median age (years): 58 (IQR 45 to 68); not reported for individual treatment groups

Male sex: $201(69.8 \%)$

Comorbid illness (cohort): asthma/COPD 14 (4.9); immunosuppressed 3 (1.0)

Disease severity: moderate to severe ARDS (Berlin definition of severe hypoxaemia defined as ratio of $\mathrm{PaO}_{2} / \mathrm{FiO}_{2}$ of $\leq 200 \mathrm{mmHg}$ and Positive End-Expiratory Pressure (PEEP) of $\geq 5 \mathrm{~cm} \mathrm{H}_{2} \mathrm{O}$, associated with bilateral opacities on chest $x$-ray that could not be fully explained by cardiac failure or fluid overload) 207 (71.9)

Interventions $\quad$ Groups: $\mathrm{CS}(\mathrm{n}=204)$ versus no $\mathrm{CS}(\mathrm{n}=84)$

Dose: low-moderate dose 168 (82.4); high dose 36 (17.6). Median dose (mg/day) 80 (IQR 40 to 120)

Definition of dose: low-moderate dose 25 to $150 \mathrm{mg} /$ day of methylprednisolone or its equivalent; high dose $>150 \mathrm{mg} /$ day of methylprednisolone or its equivalent

Duration given for: median (days) 7 (IQR 4.0 to 11.3 )

Time to initiation from onset of illness: median (days) 7.0 (IQR 5.0 to 9.4)

Antibiotics (cohort): total given antibiotics 261 (90.6); "appropriate" antibiotics 133 (46.2)

Antivirals (cohort): 285 (99.0); median initiation time (days from onset) 6.3 (IQR 4.7 to 8.2) 
Cao 2016 (Continued)

Outcomes
Mortality: 30-day and 60-day mortality adjusted hazard ratios reported (multivariate Cox regression analysis). Also compared low-moderate-dose CS versus control and high-dose CS versus control, and included a propensity score-matched case-control analysis (65 pairs)

Adverse events: hospital-acquired infections in CS versus no CS groups assessed by propensity matched pairs analysis

Viral shedding: in CS group versus no CS group assessed by propensity matched pairs analysis with further stratification according to high/low-moderate CS dose
Risk of bias (Newcastle-Ottawa Scale)

\section{Mortality}

Selection domain score $(\max 4): 4$

Comparability domain score $(\max 2): 2$

Outcome domain score $(\max 3): 3$

\section{Hospital-acquired infection}

Selection domain score $(\max 4): 4$

Comparability domain score $(\max 2): 2$

Outcome domain score $(\max 3): 2$

\section{Viral shedding}

Selection domain score $(\max 4): 4$

Comparability domain score $(\max 2): 2$

Outcome domain score $(\max 3): 2$
Adjusted estimates for 30-day and 60-day mortality presented following logistical regression in a cohort study. Separate estimates given in a propensity matched case-control study. In this study outcomes were stratified according to different corticosteroid regimens (high dose and low-to-moderate dose).

Chawla 2013

\begin{tabular}{ll}
\hline Methods & Single-centre retrospective cohort study \\
\hline Participants & Country: India (New Delhi) \\
& Setting: ICU \\
& Number of individuals: 77 \\
& Inclusion criteria: individuals with laboratory-confirmed influenza \\
& Influenza type: 2009 influenza A H1N1 virus (H1N1pdm09) \\
& Median age (years): cohort 41 (10 to 72) \\
& Male sex: cohort 44 (57.1) \\
\hline Interventions & Groups: $\mathrm{CS}(\mathrm{n}=38)$ versus no CS $(\mathrm{n}=39)$ \\
\hline Outcomes & Mortality \\
\hline
\end{tabular}


Chawla 2013 (Continued)

Risk of bias (Newcastle-Ot- Mortality

tawa Scale)

Selection domain score $(\max 4): 3$

Comparability domain score $(\max 2): 0$

Outcome domain score $(\max 3): 3$

Notes

Delaney 2016

Methods Multicentre retrospective cohort study

Participants

Country: Canada

Setting: in-hospital

Number of sites: 51

Number of individuals: 607

Inclusion criteria: critically ill adults aged $>18$ years, admitted to participating hospitals with confirmed, probable, or highly suspected H1N1pdm09 influenza

Exclusion criteria: people receiving oral or parenteral corticosteroids before onset of critical illness

Definition of influenza: laboratory-confirmed or clinically diagnosed influenza

Influenza type: 2009 influenza A H1N1 virus (H1N1pdm09)

Mean age (years): cohort $47.4( \pm 15.3)$; CS group $48.8( \pm 15.3)$; no CS group $46.2( \pm 15.2)$

Female sex: cohort 315 (51.9); CS group 152 (54.3); no CS group 163 (49.9)

\section{Comorbid illness:}

Asthma: cohort 124 (20.4); CS group 82 (29.3); no CS group 42 (12.8), $\mathrm{P}<0.001$

COPD: cohort 100 (16.4); CS group 70 (25); no CS group 30 (9.2), $\mathrm{P}<0.001$

Immunosuppression: cohort 35 (5.8); CS group 25 (8.9); no CS group 10 (3.1), $\mathrm{P}=0.002$

Disease severity: mean SOFA score (SD): cohort 11.4 (3.7); CS group 11.4 (3.8); no CS group 11.3 (3.6), P $=0.70$

Types: prednisolone $(n=189)$, methylprednisolone $(n=177)$, hydrocortisone $(n=161)$, dexamethasone $(n=22)$, cortisone $(n=1)$

Dose: median (mg/day) 227 (IQR 154 to 443)

Duration: median (days) 7.0 (IQR 4 to 13 )

Timing: median (days) from critical illness onset 0 (IQR 0 to 3)

Outcomes

In-hospital mortality: reported unadjusted and adjusted odds ratios. Different adjustment methodologies are presented: multivariate logistic regression analysis; multivariate logistic regression analysis adjusted for propensity score to receive corticosteroids; treatment groups matched on propensity to receive CS; marginal structural model adjusted for baseline and time-dependent between-group differences over the first week of ICU admission until discharge or death. 
Delaney 2016 (Continued)

Adverse events: hospital-acquired (bloodstream and respiratory) infections unadjusted outcome presented plus $\mathrm{P}$ value for outcome when matched by propensity to receive CS among critically ill patients

\title{
Risk of bias (Newcastle-Ot- Mortality
} tawa Scale)

\author{
Selection domain score $(\max 4): 4$ \\ Comparability domain score $(\max 2): 2$ \\ Outcome domain score $(\max 3): 3$

\section{Hospital-acquired infection} \\ Selection domain score $(\max 4): 4$ \\ Comparability domain score $(\max 2): 2$ \\ Outcome domain score $(\max 3): 3$
}

\begin{tabular}{ll}
\hline Methods & Multicentre prospective cohort \\
\hline Participants & Country: Spain (Andalusia, Catalonia, Castile and Leon, Madrid, Navarre, the Basque Country and Va- \\
Setting: in-hospital & Number of sites: 36 \\
& Number of individuals: 813 \\
& Inclusion criteria: influenza-like illness, acute respiratory tract infection, septic shock, multi-organ fail- \\
& ure \\
& Exclusion criteria: hospital-acquired influenza infection \\
& Definition of influenza: laboratory confirmed \\
& Influenza type: 2009 influenza A H1N1 virus (H1N1pdm09) \\
& Median age (years): cohort 41.0 (IQR 19.0 to 55.0); not reported for individual groups \\
& Female sex: cohort 410 (50.4); not reported for individual groups \\
Comorbid illness: no data for individual groups \\
Disease severity: not reported
\end{tabular}

\begin{tabular}{ll}
\hline Interventions & Groups: CS use 90 days prior to admission $(\mathrm{n}=31)$ versus no prior CS use $(\mathrm{n}=782)$ \\
\hline Outcomes & $\begin{array}{l}\text { Reported independent association between CS use with poor outcome (composite outcome of ICU ad- } \\
\text { mission and in-hospital death) and length of stay }\end{array}$
\end{tabular}

\section{Risk of bias (Newcastle-Ot- ICU admission and mortality} tawa Scale)

\author{
Selection domain score $(\max 4): 3$ \\ Comparability domain score $(\max 2): 2$
}


Delgado-Rodriguez 2012 (Continued)

Outcome domain score $(\max 3): 3$

Notes Study reporting outcomes according to pre-admission antibiotic use

Han 2011

\begin{tabular}{|c|c|}
\hline Methods & Multicentre retrospective cohort \\
\hline \multirow[t]{12}{*}{ Participants } & Country: China (Shenyang City) \\
\hline & Setting: in-hospital \\
\hline & Number of sites: 4 \\
\hline & Number of individuals: 83 \\
\hline & $\begin{array}{l}\text { Inclusion criteria: age }>3 \text { years, admitted with confirmed pandemic influenza to } 1 \text { of } 4 \text { general hospi- } \\
\text { tals during the study period }\end{array}$ \\
\hline & Exclusion criteria: medical records not retrievable \\
\hline & Definition of influenza: laboratory confirmed \\
\hline & Influenza type: 2009 influenza A H1N1 virus (H1N1pdm09) \\
\hline & Median age (years): no CS group 38 (IQR 5 to 75 ); CS group 43 (IQR 3 to 70 ) \\
\hline & Male sex: no CS group 18 (49.0); CS group 29 (63.0) \\
\hline & Comorbid illnesses: not reported individually \\
\hline & $\begin{array}{l}\text { Disease severity: Median Pandemic Medical Early Warning Score (PMEWS): no CS group } 2 \text { (IQR } 0 \text { to 5); } \\
\text { CS group } 2 \text { ( } 0 \text { to } 5 \text { ) }\end{array}$ \\
\hline \multirow[t]{4}{*}{ Interventions } & Groups: no CS group $(n=37)$ versus CS group $(n=46)$ \\
\hline & $\begin{array}{l}\text { CS group further subdivided into early treatment ( }<=72 \text { hours; } n=17 \text { ) and late treatment }(>72 \text { hours; } n \\
=29) \text {. }\end{array}$ \\
\hline & Type: methylprednisolone and dexamethasone \\
\hline & Co-interventions: antivirals \\
\hline
\end{tabular}

Outcomes

Critical illness: defined as $>=1$ of the following: death, respiratory failure, septic shock, failure or insufficiency of $>=2$ non-pulmonary organs, mechanical ventilation or ICU admission

A proportional hazards model was used to estimate the probability of developing critical disease after controlling for the presence of underlying comorbid illnesses and presence of risk factors (age >= 65 years, pregnancy, obesity).

\section{Risk of bias (Newcastle-Ot- Critical illness} tawa Scale)

Selection domain score $(\max 4): 3$

Comparability domain score $(\max 2): 2$

Outcome domain score $(\max 3): 3$ 
Huang 2017

\begin{tabular}{|c|c|}
\hline Methods & Single-centre retrospective cohort study \\
\hline \multirow[t]{13}{*}{ Participants } & Country: Taiwan \\
\hline & Setting: in-hospital \\
\hline & Number of individuals: 86 ; respiratory distress cohort $n=48 ;$ no respiratory distress cohort $n=38$ \\
\hline & Inclusion criteria: older than 18 years, hospitalised, laboratory-confirmed influenza \\
\hline & Exclusion criteria: hospital-acquired influenza and contact history \\
\hline & Definition of influenza: rapid antigen test or RT-PCR confirmed influenza \\
\hline & Influenza type: mixed \\
\hline & Mean age (years): entire cohort $65.9( \pm 19.2)$ \\
\hline & Male sex: 56 (65\%); respiratory distress cohort 27 (71.1); no respiratory distress cohort 30 (62.5) \\
\hline & Comorbid illnesses: \\
\hline & $\begin{array}{l}\text { Chronic pulmonary disease: entire cohort } 22 \text { (25.7); respiratory distress cohort } 13(27.1) \text {; no respiratory } \\
\text { distress cohort } 9 \text { (23.7) }\end{array}$ \\
\hline & $\begin{array}{l}\text { Immunosupression: entire cohort } 30 \text { (34.9); respiratory distress cohort } 16(33.3) \text {; no respiratory distress } \\
\text { cohort } 14(36.8)\end{array}$ \\
\hline & $\begin{array}{l}\text { Disease severity: } 48(55.8) \text { with respiratory distress (defined as } \mathrm{PaO}_{2} / \mathrm{FiO}_{2}<200 \mathrm{mmHg} \text { or oxygen satu- } \\
\text { ration }<90 \% \text { with a } \mathrm{FiO}_{2}>50 \% \text { ). APACHE/SOFA scores not detailed. }\end{array}$ \\
\hline
\end{tabular}

Interventions

Groups: $C S \pm$ antiviral $(n=29)$ versus antiviral only without $C S(n=19)$

Type: not reported

Dose of CS: medium- to high-dose CS defined as $\geq 0.5$ to $2 \mathrm{mg} / \mathrm{kg} /$ day, but median/mean dose not recorded

Duration of CS: short term ( $\leq 3$ days): 4 (13.8); 4 to 13 days: 14 (48.3); $\geq 14$ days: 10 (34.5) (1 person not recorded)

Timing: early (before and within 72 hours of antiviral onset) 17 (58.6); after 72 hours of antivirals 12 (41.4)

Co-interventions: all people with respiratory distress received antivirals: oseltamivir alone 33 (68.8); oseltamivir + peramivir 15 (31.2)

\section{Outcomes Respiratory distress cohort:}

All-cause mortality, raw data presented

Length of stay

Risk of bias (Newcastle-Ot- Mortality tawa Scale)

Selection domain score $(\max 4): 3$

Comparability domain score $(\max 2): 0$

Outcome domain score $(\max 3): 2$

\section{Length of stay}


Huang 2017 (Continued)

Selection domain score $(\max 4): 2$

Comparability domain score ( $\max 2): 0$

Outcome domain score $(\max 3): 1$

Notes

Study also reports mortality in those receiving early CS prior to or within 72 hours of effective antiviral treatment compared to those receiving CS more than 72 hours after antiviral initiation ( $P$ value - logrank test of Kaplan-Meier survival analysis).

Jain 2009

\begin{tabular}{ll}
\hline Methods & Multicentre retrospective cohort \\
\hline Participants & Country: USA \\
Setting: in-hospital & Number of sites: national surveillance data \\
& Number of individuals: 272 (CS data available for 239) \\
& Inclusion criteria: individuals hospitalised with influenza-like illness \\
& Definition of influenza: laboratory confirmed \\
Influenza type: 2009 influenza A H1N1 virus (H1N1pdm09) & Median age (years): cohort 21 years (IQR 21 days to 86 years) \\
& Male sex: not reported for individual groups \\
& Comorbid illnesses: not reported for individual groups \\
Disease severity: not reported for individual groups
\end{tabular}

Interventions

Groups: no CS ( $n=153)$; CS $(n=86)$

Type: not reported

Co-interventions: antivirals 200/268 (74.6); antibiotics 206/260 (79.2)

Outcomes Death/ICU admission versus survival/no ICU admission

Risk of bias (Newcastle-Ot- Death/ICU admission versus survival/no ICU admission tawa Scale)

Selection domain score $(\max 4)$ :

Comparability domain score $(\max 2): 0$

Outcome domain score $(\max 3): 3$

Notes -

Kim 2011

Methods Multicentre retrospective cohort/case-control 
Kim 2011 (Continued)

$\begin{array}{ll}\text { Participants } & \text { Country: Korea } \\ & \text { Setting: ICU }\end{array}$

Number of sites: 28

Number of individuals: 245

Inclusion criteria: age >= 15 years; presence of critical illness defined as i) admitted to ICU or required mechanical ventilation (invasive or non-invasive), or ii) had $\mathrm{PaO}_{2} / \mathrm{FiO}_{2}$ less than $300 \mathrm{mmHg}$, or iii) required intravenous infusion of an inotropic or vasoconstrictive medication)

Definition of influenza: laboratory confirmed

Influenza type: 2009 influenza A H1N1 virus (H1N1pdm09)

Mean age (years): no CS group $54.1( \pm 19.3)$; CS group $56.9( \pm 17.2)$

Male sex: no CS group 73 (53.0); CS group 61 (57.0)

\section{Comorbid illnesses:}

Asthma: CS 10 (9); no CS 9 (7)

COPD: CS 14 (13); no CS 6 (4)

Solid tumour: CS 30 (28); no CS 19 (14)

Disease severity: mean APACHE II: no CS group $17.5( \pm 8.5)$; CS group $21.2( \pm 7.7) ; P=0.001$

Dose: median prednisolone equivalent $75 \mathrm{mg} /$ day (IQR 50 to $81 \mathrm{mg} /$ day)

Duration of treatment: median 6 (IQR 6 to 13) days

Antibiotics: CS group 107 (100.0); no CS group 136 (99.0)

Antivirals: CS group 44 (41.0); no CS group 68 (49.0)

Outcomes

Mortality: 14-day, 30-day, and 90-day mortality reported. Adjusted estimates presented for 90-day mortality (following adjustment for age, SOFA score, mechanical ventilation, lymphocyte count, and propensity score)

Unadjusted estimates given for mechanical ventilation and length of stay.

Adverse events: secondary bacterial infections

Risk of bias (Newcastle-Ottawa Scale)

\section{Mortality}

Selection domain score $(\max 4): 4$

Comparability domain score $(\max 2): 2$

Outcome domain score $(\max 3): 3$

\section{Mechanical ventilation}

Selection domain score $(\max 4): 4$

Comparability domain score $(\max 2): 0$

Outcome domain score $(\max 3): 3$

\section{Length of stay}


Kim 2011 (Continued)

\author{
Selection domain score $(\max 4): 4$ \\ Comparability domain score $(\max 2): 0$ \\ Outcome domain score $(\max 3): 3$ \\ Hospital-acquired infection \\ Selection domain score $(\max 4): 4$ \\ Comparability domain score ( $\max 2): 0$ \\ Outcome domain score $(\max 3): 3$
}

Notes

Adjusted estimates for 90-day mortality presented following logistical regression in a cohort study. Separate estimates given in a propensity matched case-control study.

Kinikar 2012

\begin{tabular}{ll}
\hline Methods & Single-centre retrospective cohort \\
\hline Participants & Country: India (Pune) \\
& Setting: tertiary referral centre \\
& Number of individuals: 92 \\
& Inclusion criteria: children < 12 years, admitted to swine flu isolation ICU and ward with laborato- \\
& ry-confirmed influenza \\
& Definition of influenza: laboratory-confirmed (PCR) \\
& Influenza type: 2009 influenza A H1N1 virus (H1N1pdm09) \\
& Median age (years): cohort 2.5 (IQR 1.3 to 6) \\
& Male sex: cohort 43 (47) \\
& Comorbid illnesses: cohort asthma 4 (4); congenital heart disease 6 (7) \\
& Disease severity: 88 (96\%) admitted to ICU. 100\% had infiltrates on chest x-ray. Overall mortality $15 / 92$ \\
(16\%)
\end{tabular}

Interventions

Groups: CS treatment $(n=21)$ versus no CS treatment $(n=71)$

Dose, duration, and timing of CS treatment not recorded.

Antibiotics: $100 \%$

Antivirals: $100 \%$ oseltamivir, median time from illness onset to initiation 3 days, 14 (15\%) within 48 hours of admission

\title{
Outcomes
}

In-hospital mortality: unadjusted odds ratio presented

Risk of bias (Newcastle-Ot- In-hospital mortality: tawa Scale)

Selection domain score $(\max 4): 3$

Comparability domain score $(\max 2): 0$

Outcome domain score $(\max 3): 3$ 
Kinikar 2012 (Continued)

Notes

Kudo 2012

\begin{tabular}{ll}
\hline Methods & Single-centre retrospective cohort \\
\hline Participants & Country: Japan \\
Setting: in-hospital & Number of individuals: 89 \\
& Inclusion criteria: hospitalised patients with respiratory disorders (upper respiratory tract infection, \\
& wheezing illness, pneumonia with wheezing, and pneumonia without wheezing) \\
& Definition of influenza: laboratory confirmed \\
& Influenza type: 2009 influenza A H1N1 virus (H1N1pdm09) \\
& Median age (years): 8 (IQR 0 to 71) for cohort \\
& Male sex: 45 (50.6) in cohort \\
& Comorbid illnesses: asthma: cohort 26 (29.2) \\
& Disease severity: not reported
\end{tabular}

Interventions $\quad$ Groups: CS treatment $(n=46)$ versus no CS treatment $(n=12)$ (based on 58 individuals in cohort)

Dose: methylprednisolone 1 to $1.5 \mathrm{mg} / \mathrm{kg}, 2$ to 4 times/day

Duration of treatment: median 5.1 days

Timing of treatment: median 2.1 days following symptom onset

Antibiotics: $\mathrm{n}=63(70.8)$ given antibiotics in cohort

Antivirals: all individuals received antiviral therapy

\begin{tabular}{ll}
\hline Outcomes & Length of stay \\
\hline $\begin{array}{l}\text { Risk of bias (Newcastle-Ot- } \\
\text { tawa Scale) }\end{array}$ & Length of stay \\
& Selection domain score $(\max 4): 4$ \\
& Comparability domain score $(\max 2): 0$ \\
& Outcome domain score $(\max 3): 3$ \\
\hline Notes & - \\
\hline
\end{tabular}

Lee 2015

\begin{tabular}{ll}
\hline Methods & Multicentre retrospective cohort study \\
\hline Participants & Countries: China (Hong Kong and Beijing) and Singapore \\
& Setting: in-hospital
\end{tabular}


Lee 2015 (Continued)

\title{
Number of sites: 3 \\ Number of individuals: 2649
}

Inclusion criteria: adults $>17$ years, hospitalised with acute respiratory infection because of potentially serious complications, exacerbation of underlying condition, severe systemic/respiratory symptoms unmanageable at home or as an outpatient, laboratory-confirmed influenza

Definition of influenza: laboratory-confirmed (PCR \pm immunofluorescence and virus culture)

Influenza type: seasonal influenza A: 1212 (45.8); H1N1pdm09: 961 (36.3); undefined influenza A: 181 (6.8); influenza B: 295 (11.1)

Median age (years): cohort 63 (IQR 42 to 79 )

Male sex: $1370(51.7)$

Comorbid illness: entire cohort: chronic lung disease 561 (21.2); major systemic comorbidity 1318 (49.8)

Disease severity: ventilatory support and/or ICU: 305 (11.5); pneumonia: 1081 (40.8)

Interventions

Groups: systemic CS treatment $(n=610)$ versus no CS treatment $(n=2039)$

Dose, duration, and timing of CS treatment: not reported

Antibiotics: $2282(88.1)$

Antivirals: 1991 (75.2); median time from onset to initiation 2 days (1 to 4)

Mortality (30-day and 60-day): adjusted hazard ratios presented (multivariate Cox regression)

4 adjusted models are presented adjusting for NAI treatment, bacterial superinfection, statin and CS use, time-dependent Cox regression, and pneumonia subgroup. Adjusted hazard ratios of explanatory variables associated with death censored at 30 days and 60 days and excluding patients with known indications for CS treatment for acute COPD/asthma exacerbations were significant for CS treatment (included in analysis $n=2088$; CS for respiratory failure, pneumonia, or fever $n=254$ )

Bacterial superinfection (defined as positive culture of a bacterial pathogen from a lower respiratory tract specimen (sputum, bronchial/tracheal aspirates, or bronchoalveolar lavage) and/or blood samples collected during the acute illness, excluding results from other sites)

Length of stay: presented as adjusted estimate $(\beta)$ of the difference in length of stay days

\section{Risk of bias (Newcastle-Ot- Mortality:}

tawa Scale)

\author{
Selection domain score $(\max 4): 4$ \\ Comparability domain score $(\max 2): 2$ \\ Outcome domain score $(\max 3): 3$
}

\section{Bacterial superinfection:}

Selection domain score $(\max 4): 3$

Comparability domain score $(\max 2): 0$

Outcome domain score $(\max 3): 3$

\section{Length of stay:}

Selection domain score $(\max 4): 4$

Comparability domain score $(\max 2): 2$ 
Lee 2015 (Continued)

Outcome domain score $(\max 3): 3$

\section{Notes}

$-$

Li 2012

\begin{tabular}{ll}
\hline Methods & Multicentre retrospective cohort \\
\hline Participants & Country: China (Anhui province) \\
Setting: in-hospital & Number of sites: not known \\
& Number of individuals: 46 \\
& Inclusion criteria: pregnant, severe disease (defined as high fever for > 3 days, haemoptysis with puru- \\
& lent sputum, chest pain, dyspnoea, cyanosis, altered mental state, severe vomiting, diarrhoea and de- \\
& hydration, radiologically confirmed pneumonia, elevated cardiac enzymes, respiratory failure, sepsis, \\
& multi-organ dysfunction or admission to ICUs \\
& Exclusion criteria: discharge within 24 hours, individuals managed in the outpatient setting \\
& Definition of influenza: laboratory confirmed \\
& Influenza type: 2009 influenza A H1N1 virus (H1N1pdm09) \\
& Median age (years): adults who died 21 (IQR 18 to 31) and survivors 21 (IQR 18 to 27) \\
& Female sex: 46 (100.0) \\
& Disease severity: not reported
\end{tabular}

Interventions

Groups: CS treatment $(n=27)$ versus no CS treatment $(n=19)$

Dose: not reported

Duration of treatment: not reported

Antibiotics: not reported

Antivirals: all given antivirals

Outcomes Mortality

\section{Risk of bias (Newcastle-Ot- Mortality} tawa Scale)

Selection domain score $(\max 4): 2$

Comparability domain score $(\max 2): 0$

Outcome domain score $(\max 3): 3$

Notes -


Li 2017 (Continued)

Participants
Countries: China (mainland)

Setting: in-hospital

Number of sites: 407

Number of individuals: 2141

Inclusion criteria: adolescents and adults aged 14 years and above, hospitalised with influenza A (H1N1) pdm09 viral pneumonia, and having complete clinical information

Definition of influenza: laboratory confirmed

Influenza type: 2009 influenza A H1N1 virus (H1N1pdm09)

Median age (years): cohort 34.4 (IQR 24.1 to 51.1); CS group 35.0 (IQR 23.8 to 52.4); no CS group 33.7 (IQR 24.6 to 48.7 )

Female sex (\%): cohort 1046 (48.9); CS group 525 (49.8); no CS group 521 (48.0)

\section{Comorbid illness:}

Asthma: cohort 38 (1.8); CS group 22 (2.1); no CS group 16 (1.5), $\mathrm{P}=0.284$

COPD: cohort 106 (5.0); CS group 59 (5.6); no CS group 47 (4.3), $P=0.177$

Immunosuppressed: cohort 49 (2.3); CS group 34 (3.2); no CS group 15 (1.4), P = 0.004

Disease severity:

$\mathrm{PaO}_{2} / \mathrm{FiO}_{2}$ (mmHg): cohort 219.5 (127.9 to 326.4); CS group 173.3 (100 to 272.4); no CS group 286.2 (191.7 to 388.2), $\mathrm{P}<0.001$

Clinically defined "shock": cohort 131 (6.1); CS group 84 (8.0); no CS group 47 (4.4), $P=<0.001$

All participants had pneumonia defined as "acute lower respiratory tract infection with an opacity or infiltrate seen on chest $\mathrm{x}$-ray and interpreted as pneumonia by the treating physician".

Interventions

Dose:

Low to moderate dose, defined as 25 to $150 \mathrm{mg} /$ day: $\mathrm{n}=662$

High dose, defined as > $150 \mathrm{mg} /$ day: $\mathrm{n}=367$

Unknown dose $/<25 \mathrm{mg} /$ day: $\mathrm{n}=26$

Median dose 80 (IQR 53.3 to 160 ); mean dose $141.3 \mathrm{mg} /$ day ( \pm 142 )

Duration of treatment: median (days) 7 (IQR 4 to 8); mean (days) 7.7 ( \pm 6.8 )

Antibiotics: cohort 97.7\%; CS group 98.3\%; no CS group 94.1\%

Antivirals: cohort 95.6\%; CS group 97.2\%; no CS group $94.1 \%$

Outcomes

30-day mortality: multivariate Cox regression analysis adjusted for underlying comorbidities, baseline disease severity, NAI treatment, time to hospitalisation

ICU admission: raw data presented

Hospital-acquired infection: positive culture of a new pathogen from a lower respiratory tract specimen (sputum, bronchial/tracheal aspirates, or bronchoalveolar lavage) and/or blood samples $\geq 48$ hours after admission 
Li 2017 (Continued)

Risk of bias (Newcastle-Ottawa Scale)

\section{0-day mortality}

Selection domain score $(\max 4): 3$

Comparability domain score $(\max 2): 2$

Outcome domain score $(\max 3): 3$

\section{ICU admission}

Selection domain score $(\max 4): 3$

Comparability domain score $(\max 2): 0$

Outcome domain score $(\max 3): 3$

\section{Hospital-acquired infection}

Selection domain score $(\max 4): 3$

Comparability domain score $(\max 2): 0$

Outcome domain score $(\max 3): 2$
Adjusted estimates also presented for 60-day mortality.

In this study mortality outcomes were stratified according to different corticosteroid regimens (high dose and low to moderate dose), and also by disease severity based on $\mathrm{PaO}_{2} / \mathrm{FiO}_{2}$ on admission.

Separate estimates given in a propensity matched case-control study (265 propensity-matched pairs generated from low-moderate-dose CS group and control group, 148 pairs from high-dose CS group and control group).

Liem 2009

\begin{tabular}{ll} 
Methods & Multicentre retrospective cohort \\
\hline Participants & Country: Vietnam \\
Setting: in-hospital & Number of individuals: 67 \\
& Inclusion criteria: all hospitalised patients with influenza A (H5N1) infection \\
& Definition of influenza: laboratory confirmed \\
& Influenza type: A/H5N1 \\
& Age, median years: cohort 25 (IQR 16 to 42) \\
& Male sex: cohort 37 (55.0) \\
Comorbid illnesses: not reported &
\end{tabular}

Interventions

Groups: CS treatment $(n=29)$ versus no CS treatment $(n=38)$

Dose: methylprednisolone 1 to $3 \mathrm{mg} / \mathrm{kg} / \mathrm{day}$

Duration of treatment: up to 7 days

Antibiotics: given to 63 (94.0) of cohort 
Liem 2009 (Continued)

Antivirals: given to 55 (82.0) of cohort

Outcomes In-hospital mortality

Adjusted for the presence or absence of neutropenia as a marker of disease severity to investigate the effect of steroid treatment on outcome

Risk of bias (Newcastle-Ot- In-hospital mortality tawa Scale)

Selection domain score $(\max 4): 4$

Comparability domain score $(\max 2): 1$

Outcome domain score $(\max 3): 3$

Notes -

Linko 2011

\begin{tabular}{ll}
\hline Methods & Multicentre prospective cohort \\
\hline Participants & Country: Finland \\
Setting: ICU & Number of individuals: 132 \\
Inclusion criteria: ICU admissions with influenza \\
Definition of influenza: high clinical suspicion or laboratory confirmed \\
Influenza type: 2009 influenza A H1N1 virus (H1N1pdm09) \\
Median age (years): no CS group 44 (IQR 25 to 57); CS group 51 (40 to 56) \\
Male sex: no CS group 39 (65.0); CS group 46 (64.0) \\
Comorbid illnesses: \\
COPD: no CS group 3 (5); CS group 6 (8) \\
Other obstructive pulmonary disease: no CS group 14 (23); CS group 15 (21) \\
Disease severity (median IQR): SAPS II: no CS group 22 (15 to 30); CS group 31 (24 to 36). SOFA: no CS \\
group 3 (2 to 6); CS group 6 (2 to 8); P = 0.01
\end{tabular}

Type of steroid: methylprednisolone and/or hydrocortisone

Dose: mean (SD) of the highest methylprednisolone dose was $94 \mathrm{mg}( \pm 43 \mathrm{mg})$ and hydrocortisone 214 $\mathrm{mg}( \pm 66 \mathrm{mg})$

Timing of steroid therapy: median (IQR) days after symptom onset: 5.0 (2.8 to 8.3)

Co-interventions: antibiotics ( $84 \%$ of cohort); antivirals ( $96 \%$ of cohort) 
Linko 2011 (Continued)

Risk of bias (Newcastle-Ottawa Scale)

\section{Hospital mortality}

Selection domain score $(\max 4): 4$

Comparability domain score $(\max 2): 2$

Outcome domain score $(\max 3): 3$

\section{Mechanical ventilation}

Selection domain score $(\max 4): 4$

Comparability domain score $(\max 2): 0$

Outcome domain score $(\max 3): 3$

\section{Length of stay}

Selection domain score $(\max 4): 4$

Comparability domain score $(\max 2): 0$

Outcome domain score $(\max 3): 3$

Notes -

Mady 2012

\begin{tabular}{ll}
\hline Methods & Single-centre retrospective cohort \\
\hline Participants & Country: Saudi Arabia \\
Setting: ICU & Number of individuals: 86 \\
& Inclusion criteria: influenza with respiratory failure \\
& Definition of influenza: laboratory confirmed \\
& Influenza type: 2009 influenza A H1N1 virus (H1N1pdm09) \\
& Mean age (years): cohort 40.8. Not reported for treatment groups \\
& Male sex: cohort 64 (74.4). Not reported for treatment groups \\
& Comorbid illnesses: cohort 33 (38.3) \\
& Disease severity: mean APACHE IV score: cohort 105.6 (41 to 190); CS group versus no CS group 110.5 \\
& versus 100.6 (P > 0.05)
\end{tabular}

Type of steroid: methylprednisolone

Dose: $1 \mathrm{mg} / \mathrm{kg}$ per day for 7 days

Timing of steroid therapy: not reported

Outcomes In-hospital mortality: unadjusted estimates


Mady 2012 (Continued)

Risk of bias (Newcastle-Ot- Selection domain score (max 4): 3

tawa Scale)

Comparability domain score $(\max 2): 0$

Outcome domain score $(\max 3): 3$

Notes

Moreno 2018

\begin{tabular}{|c|c|}
\hline Methods & Prospective cohort study \\
\hline \multirow[t]{16}{*}{ Participants } & Countries: Spain \\
\hline & Setting: ICU \\
\hline & Number of sites: 148 \\
\hline & Number of individuals: 1846 \\
\hline & $\begin{array}{l}\text { Inclusion criteria: patients admitted with fever }>38^{\circ} \mathrm{C} \text {; respiratory symptoms consistent with cough, } \\
\text { sore throat, myalgia, or influenza-like illness; acute respiratory failure requiring ICU admission; and mi- } \\
\text { crobiological confirmation (RT-PCR) of influenza A, B, or C. }\end{array}$ \\
\hline & $\begin{array}{l}\text { Exclusion criteria: patients receiving CS as rescue therapy for shock or for exacerbation of COPD/asth- } \\
\text { ma; children < } 15 \text { years; non-pulmonary influenza; health care-associated pneumonia }\end{array}$ \\
\hline & Definition of influenza: laboratory confirmed \\
\hline & Influenza type: influenza A, B, or C \\
\hline & Median age (years): \\
\hline & CS group 53 (IQR 41 to 62 ); no CS group 51 (IQR 39 to 61 ) \\
\hline & Comorbid illness: \\
\hline & Asthma: CS group 79 (13.1); no CS group 75 (6.0), $\mathrm{P}<0.001$ \\
\hline & COPD: CS group 154 (25.5); no CS group 178 (14.5), $\mathrm{P}<0.001$ \\
\hline & Haematological disease: CS group 65 (10.8); no CS group 68 (5.5), $P=0.001$ \\
\hline & Disease severity: \\
\hline & Median APACHE II score: CS group 15 (10 to 20 ); no CS group 14 (10 to 19$), P=0.004$ \\
\hline
\end{tabular}

Interventions

Groups: CS treatment $(n=604)$ versus no CS treatment $(n=1242)$

Type of steroid: methylprednisolone 578 (95.7); prednisolone 23 (3.8); dexamethasone 3 (0.5)

Dose: median $80 \mathrm{mg} /$ day (60 to $120 \mathrm{mg} /$ day) methylprednisolone equivalent

Duration: median 7 (5 to 10$)$ days

Timing of steroid therapy: within first 24 hours of ICU admission

Co-interventions: antivirals: CS group 591 (97.8); no CS group 1198 (96.8)

Outcomes

ICU mortality: adjusted hazard ratios using Cox proportional hazards with propensity score matching analysis 
Moreno 2018 (Continued)

\section{ICU length of stay}

Mechanical ventilation: multivariable analysis odds ratio

Risk of bias (Newcastle-Ot- ICU mortality:

tawa Scale)

Selection domain score $(\max 4): 4$

Comparability domain score $(\max 2): 2$

Outcome domain score $(\max 3): 3$

\section{ICU length of stay:}

Selection domain score $(\max 4): 4$

Comparability domain score $(\max 2): 0$

Outcome domain score $(\max 3): 2$

Mechanical ventilation:

Selection domain score $(\max 4): 4$

Comparability domain score $(\max 2): 1$

Outcome domain score $(\max 3): 2$

Notes

The analysis in this study supercedes that of a previously included report, Diaz 2012, and includes patients with all influenza types over a longer period of time and with the exclusion of patients receiving CS for causes other than viral pneumonia.

Ono 2016

Methods Retrospective analysis of Japan Medical Center Database data

\section{Participants}

Country: Japan

Setting: database of approximately 1.5 million insured individuals (mostly employees of Japanese companies and their families)

Number of individuals: 88,054

Inclusion criteria: age $<65$ years with influenza and confirmed by influenza testing, first episode of influenza hospitalisation during the study period

Exclusion criteria: people already hospitalised for diseases other than influenza, type of influenza not recorded

Definition of influenza: laboratory confirmed

Influenza type: seasonal

Median age (years): not recorded

Female sex: non-hospitalised 39,122/87,778 (44.6\%); hospitalised 141/276 (51.1\%) 
Ono 2016 (Continued)

Outcomes Hospitalisation: multivariate Cox regression analysis hazard ratio presented adjusted for gender, age, comorbidities, respiratory co-infection, virus type

Risk of bias (Newcastle-Ot- Selection domain score $(\max 4): 2$

tawa Scale)

Comparability domain score $(\max 2): 1$

Outcome domain score ( $\max 3): 2$

Notes

Study reporting outcomes according to regular CS use prior to the diagnosis of influenza rather than CS as adjunctive treatment for influenza

Patel 2013

\begin{tabular}{ll}
\hline Methods & Single-centre retrospective cohort study \\
\hline Participants & Country: India (Gujarat) \\
Setting: in-hospital \\
Number of individuals: 63 \\
Definition of influenza: laboratory confirmed \\
Influenza type: 2009 influenza A H1N1 virus (H1N1pdm09) \\
Median age (years): 34 (IQR 3 to 69) \\
Male sex: 41 (65\%)
\end{tabular}

Interventions

Groups: CS treatment $(n=39)$; no CS treatment $(n=24)$

Type of steroid: methylprednisolone

Dose: $40 \mathrm{mg} 3$ times daily for 1 week, twice daily for 1 week, and once daily for 1 week

Route of administration: intravenous

Timing of steroid therapy: not reported

\begin{tabular}{ll}
\hline Outcomes & Mortality \\
\hline $\begin{array}{ll}\text { Risk of bias (Newcastle-Ot- } \\
\text { tawa Scale) }\end{array}$ & Selection domain score $(\max 4): 2$ \\
& Comparability domain score $(\max 2): 0$ \\
& Outcome domain score $(\max 3): 3$ \\
\hline Notes & - \\
\hline
\end{tabular}

Sertogullarindan 2011

\begin{tabular}{ll}
\hline Methods & Single-centre prospective cohort \\
\hline Participants & Country: Turkey \\
& Setting: ICU \\
\hline
\end{tabular}


Number of individuals: 20

Inclusion criteria: ICU admissions with severe community-acquired pneumonia and influenza

Definition of influenza: laboratory confirmed

Influenza type: 2009 influenza A H1N1 virus (H1N1pdm09)

Median age (years): cohort 36 (IQR 15 to 72 ); not reported by CS treatment groups

Male sex: cohort 10 (50.0); not reported by CS treatment groups

Comorbid illnesses:

COPD: cohort 2 (10)

Malignancy: cohort 2 (10)

Disease severity: not reported

Interventions

Groups: CS treatment $(n=11)$ versus no CS treatment $(n=9)$

Co-interventions: antibiotics ( $90 \%$ of cohort); antivirals ( $100 \%$ of cohort)

\begin{tabular}{ll}
\hline Outcomes & Mortality (unadjusted estimates) \\
\hline $\begin{array}{ll}\text { Risk of bias (Newcastle-Ot- } \\
\text { tawa Scale) }\end{array}$ & Selection domain score $(\max 4): 3$ \\
& Comparability domain score $(\max 2): 0$ \\
& Outcome domain score $(\max 3): 3$ \\
\hline Notes & - \\
\hline
\end{tabular}

Sheu 2017

Methods Multicentre retrospective cohort study

Participants

Country: Taiwan

Setting: ICUs in tertiary referral centres

Number of sites: 7

Number of individuals: 192

Inclusion criteria: admitted to ICU with virologically confirmed influenza

Exclusion criteria: people without ARDS

Definition of influenza: laboratory confirmed

Influenza type: seasonal

Mean age (years): cohort 58.3; not reported by CS treatment groups

Male sex: cohort $62.5 \%$

Comorbid illnesses: entire cohort "chronic airway disease" $12.5 \%$

Disease severity (\%): "severe" ARDS n = 120 (62.5); "moderate" ARDS n = 56 (29.2); "mild" ARDS n = 16 (8.3) 
Sheu 2017 (Continued)

Interventions

Groups: early CS treatment, defined as CS used within 7 days of ICU admission ( $n=101)$ versus no CS treatment $(n=91)$

No details of dose, frequency, duration of CS treatment

Outcomes

In-hospital mortality: Cox's proportional hazards models, adjusted for age, gender, APACHE II score, and ARDS severity

Risk of bias (Newcastle-Ot- Not evaluated tawa Scale)

Notes Conference abstract only

Viasus 2011

\begin{tabular}{ll}
\hline Methods & Multicentre prospective cohort study \\
\hline Participants & Country: Spain \\
Setting: in-hospital & Number of sites: 13 \\
& Number of individuals: 197 \\
& Inclusion criteria: non-immunosuppressed individuals admitted for at least 24 hours with influenza A \\
& Exclusion criteria: chemotherapy/solid organ transplant/HIV/neutropenia/ICU admission on admis- \\
& sion to hospital \\
& Definition of influenza: laboratory confirmed (PCR or culture) \\
& Influenza type: 2009 influenza A H1N1 virus (H1N1pdm09) \\
& Median age (years): no CS group 35 (IQR 28 to 47); CS group 44 (IQR 36 to 53) \\
& Male sex: no CS group 73 (53.0); CS group 61 (57.0) \\
& Comorbid illnesses: chronic pulmonary disease: no CS 22 (17.1); CS 17 (45.9) \\
Disease severity: number of individuals in high-risk Pneumonia Severity Index risk classes: CS group 8 \\
(21.6); no CS group 8 (6.4), P = 0.05
\end{tabular}

Interventions Groups: compared adults receiving immunomodulatory therapy $(n=68)(\mathrm{CS}(n=37)$, statins $(n=12)$, or macrolides $(n=31))$ versus adults not receiving immunomodulatory therapy $(n=129)$

Duration: median days 9 (5 to 13.5$)$

\begin{tabular}{|c|c|}
\hline Outcomes & $\begin{array}{l}\text { In-hospital mortality } \\
\text { Hospital-acquired infection }\end{array}$ \\
\hline \multirow{4}{*}{$\begin{array}{l}\text { Risk of bias (Newcastle-Ot- } \\
\text { tawa Scale) }\end{array}$} & In-hospital mortality \\
\hline & Selection domain score $(\max 4): 4$ \\
\hline & Comparability domain score $(\max 2): 0$ \\
\hline & Outcome domain score $(\max 3): 3$ \\
\hline
\end{tabular}

Hospital-acquired infection 
Viasus 2011 (Continued)

$$
\begin{aligned}
& \text { Selection domain score }(\max 4): 4 \\
& \text { Comparability domain score }(\max 2): 0 \\
& \text { Outcome domain score }(\max 3): 3
\end{aligned}
$$

\section{Notes}

\section{Wirz 2016}

\section{Methods}

Randomised controlled trial of prednisone in community-acquired pneumonia caused by different pathogens, with subgroup analysis of people with confirmed influenza infection

\section{Participants}

\section{Country: Switzerland}

Setting: tertiary care centres

\section{Number of sites: 7}

Number of individuals: 785 participants (in intention-to-treat analysis); CS group ( $n=392)$; placebo group $(n=393) .726$ in per-protocol population. 24 participants in subgroup with laboratory-confirmed influenza (CS group $(n=11)$; placebo group $(n=13)$ )

Inclusion criteria: consecutive adults $\geq 18$ years enrolled within 24 hours of presentation at emergency departments or medical wards with community-acquired pneumonia (new infiltrate on chest $x$-ray and the presence of at least 1 of cough, sputum production, dyspnoea, core body temperature $\geq 38.0^{\circ} \mathrm{C}$, abnormal breathing sounds or rales, leucocyte count $>10,000$ cells $/ \mu \mathrm{L}$ or $<4000$ cells $/ \mu \mathrm{L}$ )

Exclusion criteria: permanent inability for informed consent, active intravenous drug use, acute burn injury, gastrointestinal bleeding in past 3 months, known adrenal insufficiency, condition requiring more than $0.5 \mathrm{mg} / \mathrm{kg} /$ day prednisone equivalent, pregnancy or breastfeeding, severe immunosuppression (infection with HIV and CD4 count $<350$ cells/ $\mu \mathrm{L}$, immunosuppressive therapy after solid organ transplant, neutropenia $<500$ cells $/ \mu \mathrm{L}$, cystic fibrosis, or active tuberculosis)

Definition of influenza: laboratory confirmed (PCR)

Influenza type: seasonal

Mean age (years): CS group $70.3( \pm 17.5)$; placebo group $69.0( \pm 17.0)$. No separate data for influenza-confirmed subgroup

Male sex: CS group 223 (61.6); placebo group 228 (62.6)

\section{Comorbid illness:}

COPD: CS group 70 (19.3); placebo group 56 (15.4)

Diabetes mellitus: CS group 66 (18.2); placebo group 73 (20.1)

Heart failure: CS group 73 (20.2); placebo group 57 (15.7)

Cerebrovascular disease: CS group 32 (8.8); placebo group 29 (8.0)

Renal insufficiency: CS group 114 (31.5); placebo group 115 (31.6)

Neoplastic disease: CS group 27 (7.5); placebo group 22 (6.0)

Liver disease: CS group 17 (4.7); placebo group 11 (3.0)

Disease severity: total Pneumonia Severity Index score points mean: CS group $92.5 \pm 38.2$; placebo group $89.2 \pm 35.3$ 
Wirz 2016 (Continued)

Interventions
Groups (confirmed influenza): oral prednisone $(n=11)$; placebo $(n=13)$

Dose: $50 \mathrm{mg} / \mathrm{day}$

Duration: 7 days

Antibiotic therapy (all participants): CS group 355 (98.1); placebo group 357 (98.1)

Antiviral therapy: not recorded

Outcomes

Primary endpoint: time to clinical stability defined as stabilisation of vital signs at 2 consecutive measurements $\geq 12$ hours apart (adjusted hazard ratio based on Cox proportional hazards regression, censored at day 30 )

Secondary outcomes: length of hospital stay, all-cause mortality, rehospitalisation within 30 days, secondary ICU admission (defined as a participant initially admitted to the regular ward and transferred to ICU after study medication had been given), duration of total and intravenous antimicrobial therapy, incidence of complications from admission until day 30

Risk of bias (Newcastle-Ot- -

tawa Scale)

Notes

The primary endpoint in this randomised controlled trial was time to clinical stabilisation in people with community-acquired pneumonia due to a range of pathogens and was not powered to estimate the effect of prednisone in the small number of participants with influenza-confirmed pneumonia.

\section{Risk of bias}

\begin{tabular}{|c|c|c|}
\hline Bias & Authors' judgement & Support for judgement \\
\hline $\begin{array}{l}\text { Random sequence genera- } \\
\text { tion (selection bias) }\end{array}$ & Low risk & $\begin{array}{l}\text { Variable block sizes of } 4 \text { to } 6 \text { and participants stratified at time of study by } \\
\text { study centre. }\end{array}$ \\
\hline $\begin{array}{l}\text { Allocation concealment } \\
\text { (selection bias) }\end{array}$ & Low risk & $\begin{array}{l}\text { Prespecified computer-generated randomisation list kept centrally at pharma- } \\
\text { cy of main study centre. }\end{array}$ \\
\hline $\begin{array}{l}\text { Blinding of participants } \\
\text { and personnel (perfor- } \\
\text { mance bias) } \\
\text { All outcomes }\end{array}$ & Low risk & Participants, treating physicians, investigators, and data assessors blinded. \\
\hline $\begin{array}{l}\text { Blinding of outcome as- } \\
\text { sessment (detection bias) } \\
\text { All outcomes }\end{array}$ & Low risk & Outcome assessment based on objective measurements and medical records. \\
\hline $\begin{array}{l}\text { Incomplete outcome data } \\
\text { (attrition bias) } \\
\text { All outcomes }\end{array}$ & Low risk & Outcome data appear complete. \\
\hline $\begin{array}{l}\text { Selective reporting (re- } \\
\text { porting bias) }\end{array}$ & Unclear risk & Subgroup analysis by individual pathogens not specified in protocol. \\
\hline Other bias & High risk & $\begin{array}{l}\text { Some baseline differences in disease severity and comorbidities between CS } \\
\text { and placebo arms. Under-representation of sickest patients in ICU and those } \\
\text { with sepsis. Systematic testing for respiratory viruses only began in all en- } \\
\text { rolled participants } 2 \text { years after the onset of the study. }\end{array}$ \\
\hline
\end{tabular}


Wu 2012

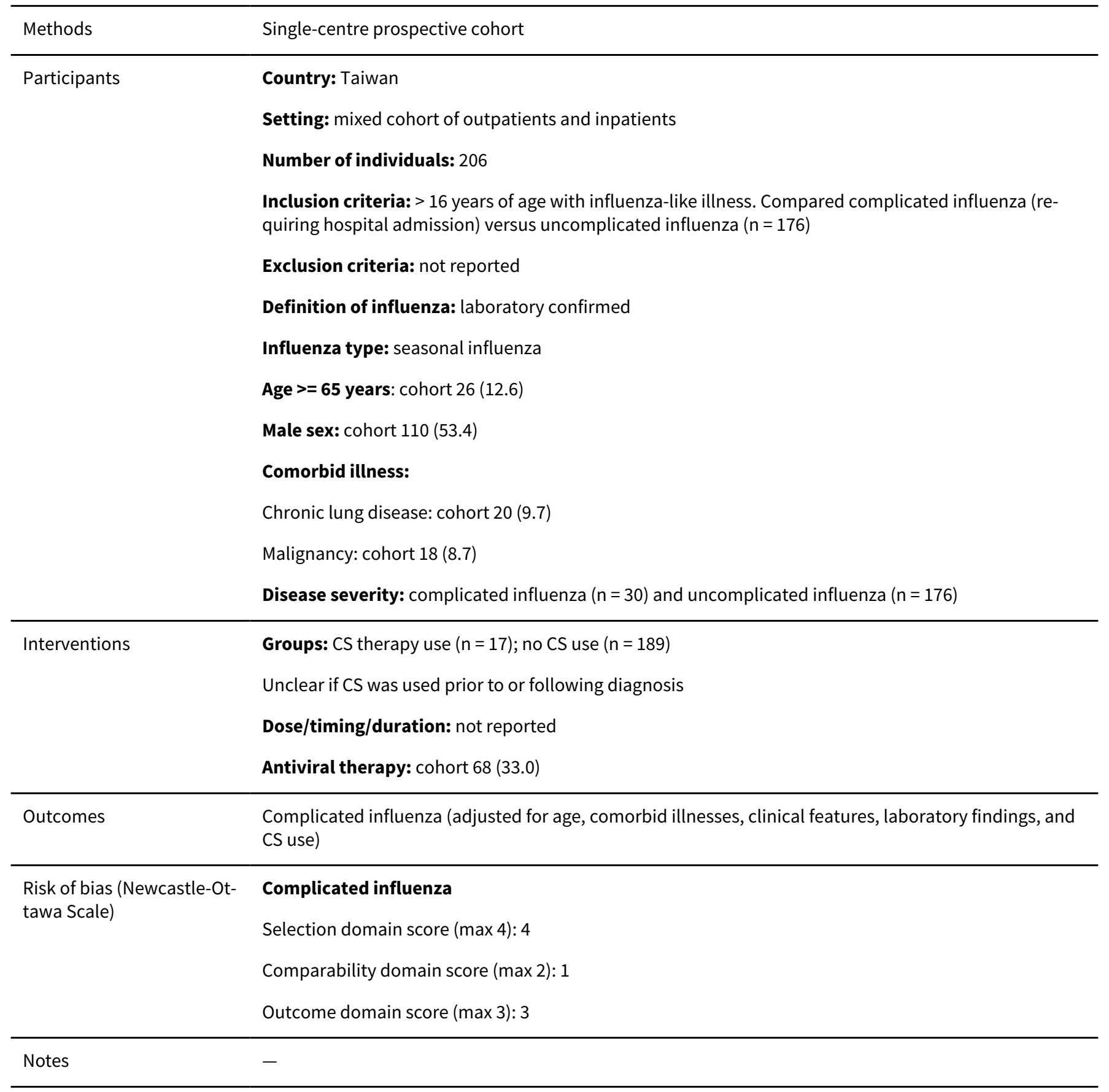

Xi 2010

Methods

Multicentre retrospective cohort study

Participants

Country: China (Beijing)

Setting: in-hospital

Number of sites: 23

Number of individuals: 155 
Xi 2010 (Continued)

Inclusion criteria: adults aged $>=18$ years admitted to hospital

Definition of influenza: laboratory confirmed

Influenza type: 2009 influenza A H1N1 virus (H1N1pdm09)

Mean (SD) age (years): cohort $43( \pm 18.6)$

Male sex: cohort 90 (58.1)

Comorbid illness: COPD: cohort 10 (6.5\%)

Disease severity: acute respiratory failure (24/103 (23.3\%) in the no CS group versus $38 / 52(73.1 \%)$ in the CS group); septic shock (5/103 (4.9\%) in the no CS group versus 13/103 (25.0\%) in the CS group); invasive ventilation (16/103 (15.5\%) in the no CS group versus $27 / 52(51.9 \%)$ in the CS group)

Interventions

Groups: primary comparison was survivors versus non-survivors. Secondary comparison made of CS treatment $(n=52)$ versus no CS treatment $(n=103)$.

Dose: daily median dose equivalent to $80 \mathrm{mg}$ (IQR $80 \mathrm{mg}$ to $160 \mathrm{mg}$ ) of methylprednisolone

Co-interventions: antivirals given to $n=132$ (85.2) of cohort; antibiotics given to $n=139$ (89.7) of cohort

Outcomes

Hospital mortality: raw numbers for mortality were derived from data provided in article. Adjusted odds ratio for mortality given for CS use in multivariate analysis.

Adjustment was made for ethnicity, comorbid illness (hypertension, diabetes), symptoms at disease onset (dyspnoea, sore throat), clinical presentation (dyspnoea), laboratory testing (lactate dehydrogenase), and CS treatment in the multivariate analysis.

No difference in mortality for low-dose CS (<80 mg of methylprednisolone) versus high-dose CS in a subgroup analysis $(9 / 30$ versus $8 / 22, P=0.854)$

Risk of bias (Newcastle-Ot- Selection domain score $(\max 4): 3$ tawa Scale)

Comparability domain score $(\max 2): 1$

Outcome domain score $(\max 3): 3$

\begin{tabular}{ll}
\hline Methods & Multicentre retrospective cohort study \\
\hline Participants & Country: China (Zhengzhou city) \\
Setting: ICU & Number of sites: 4 \\
& Number of individuals: 128 \\
& Inclusion criteria: not recorded \\
& Influenza type: 2009 influenza A H1N1 virus (H1N1pdm09) \\
& Mean (SD) age (years): males 28.5 (16.4); females 28.5 (20.4), range 8 months to 79 years \\
& Male sex: 77 (60.2\%)
\end{tabular}


Yu 2011a (Continued)

Comorbid illness: not recorded

Disease severity: not recorded

\begin{tabular}{ll}
\hline Interventions & Groups: CS ( $\mathrm{n}=54$ ) versus no CS $(\mathrm{n}=74)$ \\
& No details on types and doses of CS \\
& Duration of treatment in days: mean (SD): died 8.3 (8.0); survived 2.6 (4.2) \\
\hline Outcomes & $\begin{array}{l}\text { Mortality (time point not recorded). Raw data presented without unadjusted or adjusted odds ratio es- } \\
\text { timates. }\end{array}$ \\
\hline $\begin{array}{l}\text { Risk of bias (Newcastle-Ot- } \\
\text { tawa Scale) }\end{array}$ & Selection domain score (max 4): 2 \\
& Comparability domain score (max 2): 1 \\
\hline Ootes & Outcome domain score (max 3): 1 \\
\hline
\end{tabular}

APACHE: Acute Physiology and Chronic Health Evaluation

ARDS: adult respiratory distress syndrome

$\mathrm{Cl}$ : confidence interval

COPD: chronic obstructive pulmonary disease

CS: corticosteroid

ICU: intensive care unit

IQR: interquartile range

NAl: neuraminidase inhibitor

$\mathrm{PaO}_{2} / \mathrm{FiO}_{2}$ : ratio of partial pressure of oxygen in arterial blood to inspired fraction of oxygen

PCR: polymerase chain reaction

RT-PCR: reverse transcription-polymerase chain reaction

SAPS: Simplified Acute Physiology Score

SD: standard deviation

SOFA: Sequential Organ Failure Assessment

Characteristics of excluded studies [ordered by study ID]

\begin{tabular}{ll}
\hline Study & Reason for exclusion \\
\hline Chan 2014 & No outcome data comparing corticosteroid treatment versus no corticosteroid treatment \\
\hline Chen 2010 & Case series \\
\hline Chien 2010 & No useable data relating to corticosteroid use (only P values) \\
\hline Chotpitayasunondh 2005 & Case series \\
\hline Diaz 2012 & Overlapping cohort, superceded by later analysis \\
\hline
\end{tabular}




\begin{tabular}{|c|c|}
\hline Study & Reason for exclusion \\
\hline Dominguez-Cherit 2016 & No outcome data comparing corticosteroid treatment versus no corticosteroid treatment \\
\hline Fujikura 2014 & No outcome data comparing corticosteroid treatment versus no corticosteroid treatment \\
\hline Gao 2013 & No outcome data comparing corticosteroid treatment versus no corticosteroid treatment \\
\hline Garnacho-Montero 2013 & Overlapping populations* \\
\hline Hien 2009 & Overlapping populations* \\
\hline Hong 2013 & Overlapping populations* \\
\hline Hu 2013 & No outcome data comparing corticosteroid treatment versus no corticosteroid treatment \\
\hline Jung 2011 & Overlapping populations* \\
\hline Leon 2017 & Overlapping populations* \\
\hline Martin-Loeches 2013 & Overlapping populations* \\
\hline McKenna 2013 & Overlapping populations* \\
\hline Ning 2014 & Fewer than 10 participants in study \\
\hline Okur 2013 & Overlapping populations* \\
\hline Perez-Padilla 2009 & Case series \\
\hline Rios 2011 & No outcome data comparing corticosteroid treatment versus no corticosteroid treatment \\
\hline Segaloff 2017 & No outcome data comparing corticosteroid treatment versus no corticosteroid treatment \\
\hline Singh 2017 & No outcome data clearly comparing corticosteroid treatment versus no corticosteroid treatment \\
\hline Smud 2010 & No outcome data comparing corticosteroid treatment versus no corticosteroid treatment \\
\hline Sun 2010 & Case series \\
\hline Torres 2012 & No data on clinical outcomes \\
\hline Vilar-Compte 2018 & $\begin{array}{l}\text { No outcome data comparing corticosteroid treatment versus no corticosteroid treatment; corticos } \\
\text { teroid use within } 30 \text { days of infection only }\end{array}$ \\
\hline Yale 2015 & No data on clinical outcomes \\
\hline Yang 2015a & Overlapping populations* \\
\hline Zhang 2011 & Outcomes unclear \\
\hline Zhang 2013 & Overlapping populations* \\
\hline
\end{tabular}

*Overlapping populations refers to studies where data from cohorts included in the review were duplicated, either due to multiple reporting of the same cohort, or inclusion of the cohort within the study population of a larger study. 


\section{DATA AND ANALYSES}

Comparison 1. Corticosteroid therapy versus no corticosteroid therapy

\begin{tabular}{|c|c|c|c|c|}
\hline Outcome or subgroup title & $\begin{array}{l}\text { No. of } \\
\text { studies }\end{array}$ & $\begin{array}{l}\text { No. of } \\
\text { partici- } \\
\text { pants }\end{array}$ & Statistical method & Effect size \\
\hline $\begin{array}{l}1 \text { Mortality following admission, hospitalised partici- } \\
\text { pants - studies reporting odds ratios }\end{array}$ & 15 & 2212 & $\begin{array}{l}\text { Odds Ratio (Random, 95\% } \\
\mathrm{Cl} \text { ) }\end{array}$ & $\begin{array}{l}3.90[2.31 \\
6.60]\end{array}$ \\
\hline 1.1 Unadjusted mortality & 10 & 1006 & $\begin{array}{l}\text { Odds Ratio (Random, 95\% } \\
\text { Cl) }\end{array}$ & $\begin{array}{l}4.79[2.35, \\
9.79]\end{array}$ \\
\hline 1.2 Adjusted mortality & 5 & 1206 & $\begin{array}{l}\text { Odds Ratio (Random, 95\% } \\
\mathrm{Cl} \text { ) }\end{array}$ & $\begin{array}{l}2.23[1.54, \\
3.24]\end{array}$ \\
\hline $\begin{array}{l}2 \text { Mortality following admission, hospitalised partici- } \\
\text { pants - studies reporting hazard ratios }\end{array}$ & 6 & & $\begin{array}{l}\text { Hazard Ratio (Random, 95\% } \\
\mathrm{Cl} \text { ) }\end{array}$ & $\begin{array}{l}1.49[1.09, \\
2.02]\end{array}$ \\
\hline $\begin{array}{l}3 \text { Adverse events secondary to corticosteroid use: hospi- } \\
\text { tal-acquired infection in hospitalised participants }\end{array}$ & 7 & 6114 & $\begin{array}{l}\text { Odds Ratio (M-H, Random, } \\
95 \% \mathrm{Cl})\end{array}$ & $\begin{array}{l}2.74[1.51, \\
4.95]\end{array}$ \\
\hline
\end{tabular}

\section{Analysis 1.1. Comparison 1 Corticosteroid therapy versus no corticosteroid therapy, Outcome} 1 Mortality following admission, hospitalised participants - studies reporting odds ratios.

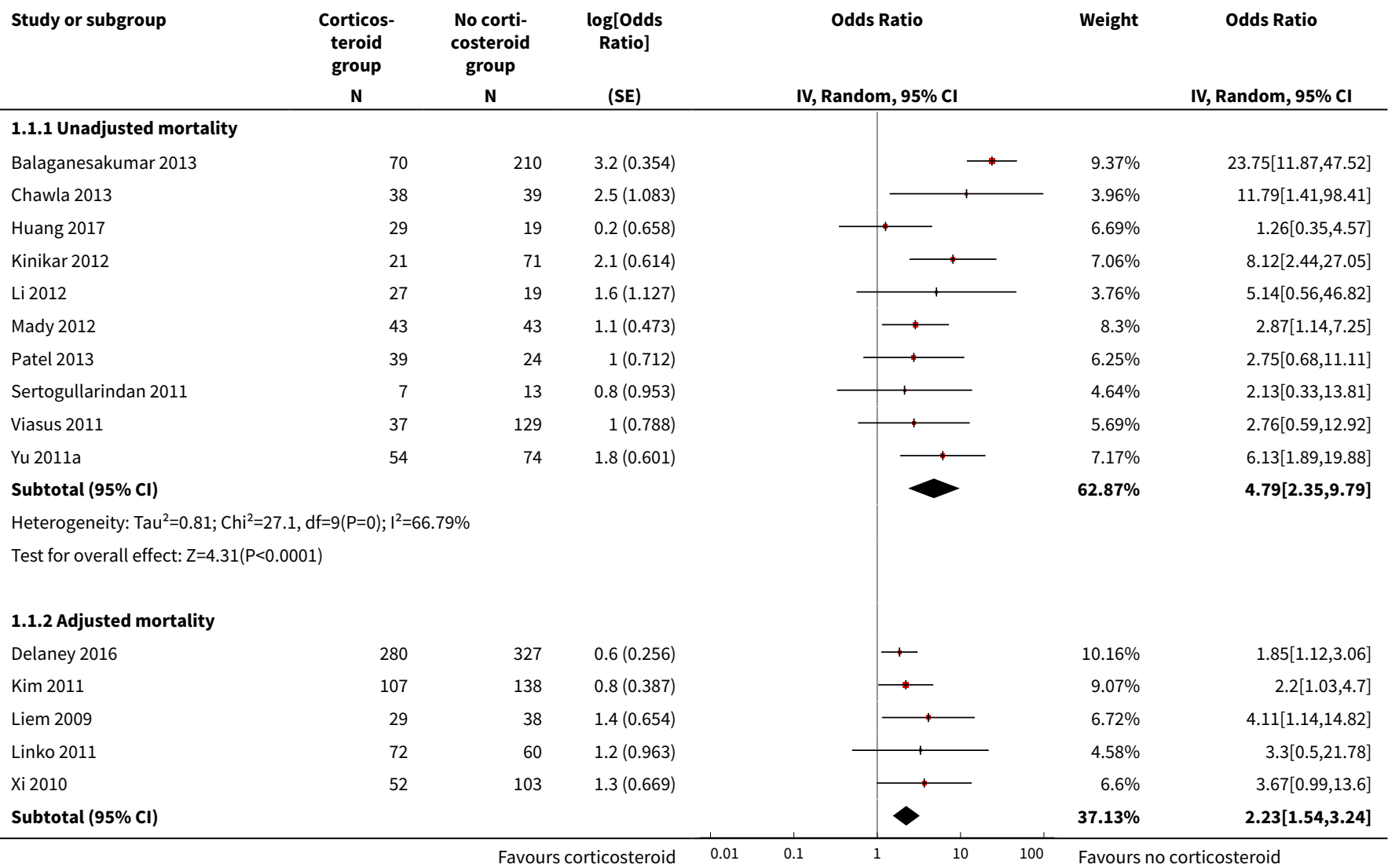




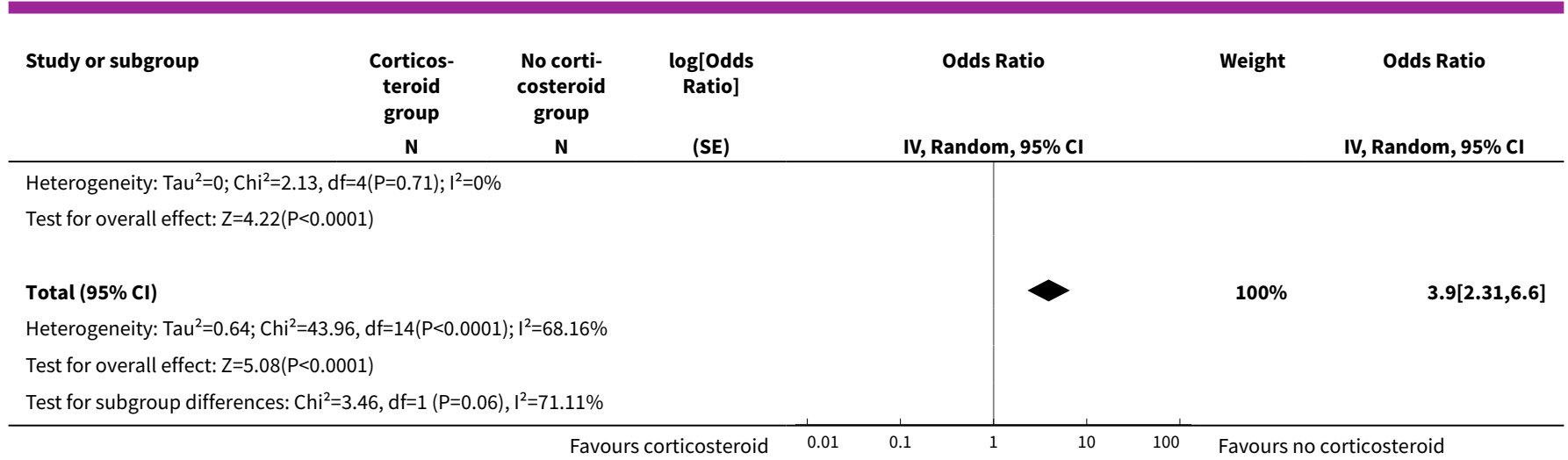

\section{Analysis 1.2. Comparison 1 Corticosteroid therapy versus no corticosteroid therapy, Outcome} 2 Mortality following admission, hospitalised participants - studies reporting hazard ratios.

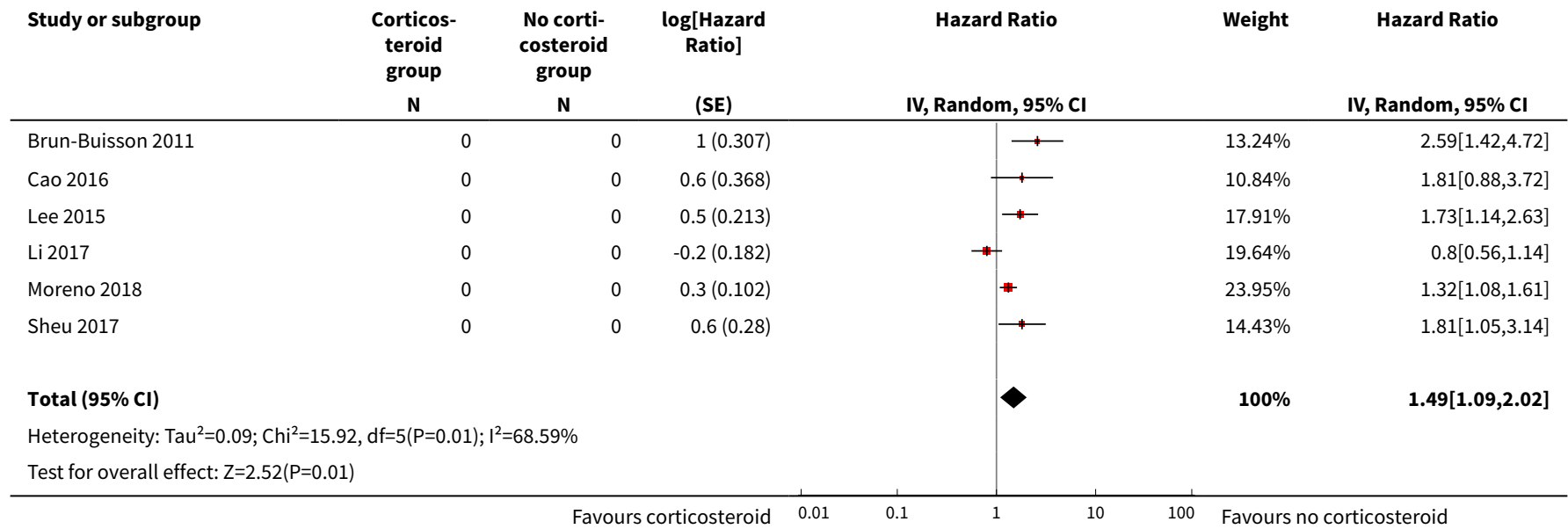

Analysis 1.3. Comparison 1 Corticosteroid therapy versus no corticosteroid therapy, Outcome 3 Adverse events secondary to corticosteroid use: hospital-acquired infection in hospitalised participants.

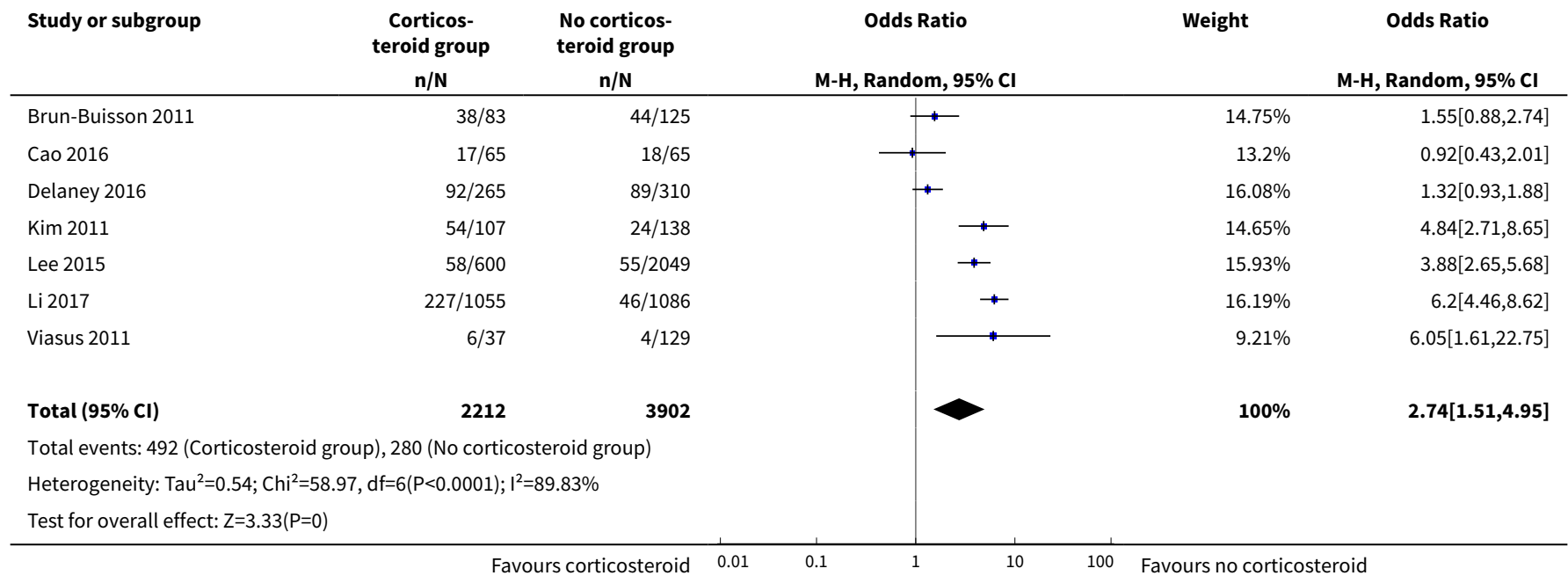


ADDITIONAL TABLES 
Table 1. Summary of included studies

$\begin{array}{lllllll}\begin{array}{l}\text { Study/year } \\ \text { (country) }\end{array} & \text { Design } & \begin{array}{l}\text { Setting/in- } \\ \text { clusion cri- } \\ \text { teria }\end{array} & \text { CS given }(n) & \begin{array}{l}\text { CS not giv- } \\ \text { en }(n)\end{array} & \text { Demographics } & \begin{array}{l}\text { Disease } \\ \text { severity } \\ \text { scores }\end{array}\end{array}$

Studies included in meta-analysis

Influenza 2009 influenza A H1N1 virus (H1N1pdm09)

\begin{tabular}{|c|c|c|c|c|c|c|c|c|}
\hline $\begin{array}{l}\text { Balagane- } \\
\text { sakumar } \\
\text { 2013(In- } \\
\text { dia - Tamil } \\
\text { Nadu) }\end{array}$ & $\begin{array}{l}\text { Multicentre } \\
\text { prospective } \\
\text { cohort study }\end{array}$ & $\begin{array}{l}\text { In-hospi- } \\
\text { tal/admis- } \\
\text { sions with } \\
\text { influenza }\end{array}$ & 70 & 210 & $\begin{array}{l}\text { Median age (years): } 26 \text { (1 to } \\
\text { 82) }\end{array}$ & $\begin{array}{l}\text { Not re- } \\
\text { ported }\end{array}$ & Not reported & Mortality \\
\hline $\begin{array}{l}\text { Brun- } \\
\text { Buisson } \\
\text { 2011(France) }\end{array}$ & $\begin{array}{l}\text { Multicentre } \\
\text { retrospec- } \\
\text { tive analysis } \\
\text { of prospec- } \\
\text { tively col- } \\
\text { lected data }\end{array}$ & $\begin{array}{l}\text { ICU/severe } \\
\text { respirato- } \\
\text { ry failure } \\
\text { (ARDS or } \\
\text { MV) }\end{array}$ & $\begin{array}{l}83 \text { (early CS } \\
50 \text { and late } \\
\text { CS 33) }\end{array}$ & 125 & $\begin{array}{l}\text { Median age (years): no CS } 45 \\
\text { ( } 35 \text { to } 55 \text { ); CS } 49 \text { (34 to } 56 \text { ) } \\
\text { Immunosuppression: no CS } \\
18.4 \% \text {; CS } 21.7 \%\end{array}$ & $\begin{array}{l}\text { Median } \\
\text { SAPS III } \\
\text { cohort } \\
52.0 \text { ( } 44.0 \\
\text { to } 64.0 \text { ); } \\
\text { no CS } \\
\text { group } 53.0 \\
\text { (46.0 to } \\
66.0) ; \text { CS } \\
\text { group } 51.0 \\
\text { (44.0 to } \\
61.0) ; P= \\
0.25\end{array}$ & $\begin{array}{l}\text { Median daily dose: } 270 \mathrm{mg} \text { ( } 200 \\
\text { to } 400 \mathrm{mg} \text { ) of hydrocortisone } \\
\text { equivalent } \\
\text { Timing: within median } 1 \text { day ( } 0 \text { to } \\
\text { 6) of MV } \\
\text { Duration: median } 11 \text { days ( } 6 \text { to } \\
\text { 20) }\end{array}$ & $\begin{array}{l}\text { Hospi- } \\
\text { tal mor- } \\
\text { tality, } \\
\text { length of } \\
\text { ICU stay, } \\
\text { adverse } \\
\text { events }\end{array}$ \\
\hline \multirow[t]{2}{*}{$\begin{array}{l}\text { Delaney } \\
\text { 2016(Cana- } \\
\text { da) }\end{array}$} & $\begin{array}{l}\text { Multicentre } \\
\text { prospective } \\
\text { cohort study }\end{array}$ & $\begin{array}{l}\text { ICU/age } \geq 18 \\
\text { years; criti- } \\
\text { cally ill with } \\
\text { confirmed, } \\
\text { probable, or } \\
\text { highly sus- } \\
\text { pected in- } \\
\text { fluenza }\end{array}$ & 280 & 327 & $\begin{array}{l}\text { Mean age (years): no CS } 46.2 \\
( \pm 15.2) ; \text { CS } 48.8( \pm 15.3) \\
\text { Asthma: CS } 29.3 \% \text {; no CS } \\
12.8 \% ; P<0.001 \\
\text { COPD: CS } 25.0 \% \text {; no CS } 9.2 \% \text {; } \\
\text { P<0.001 }\end{array}$ & $\begin{array}{l}\text { Mean } \\
\text { APACHE } \\
\text { II score: } \\
\text { CS } 21.2 \\
( \pm 10.3) ; \\
\text { no CS } 20.1 \\
( \pm 9.7) ; P= \\
0.22\end{array}$ & $\begin{array}{l}\text { Median daily dose: } 227 \mathrm{mg} \text { ( } 154 \\
\text { to } 443 \mathrm{mg} \text { ) of hydrocortisone } \\
\text { equivalent } \\
\text { Timing: median } 0 \text { days ( } 0 \text { to } 3 \text { ) of } \\
\text { critical illness onset; median } 2 \\
\text { days ( } 1 \text { to } 8 \text { ) from hospital admis- } \\
\text { sion }\end{array}$ & \multirow[t]{2}{*}{$\begin{array}{l}\text { Mortali- } \\
\text { ty, hos- } \\
\text { pital-ac- } \\
\text { quired } \\
\text { infec- } \\
\text { tions }\end{array}$} \\
\hline & & & & & Immunosuppressed: CS 8.9\%; & & Duration: median 7 days ( 4 to 13 ) & \\
\hline
\end{tabular}


Table 1. Summary of included studies (Continued)

Mean SO-

FA score:

CS 11.4

$( \pm 3.8)$; no

CS 11.3

$( \pm 3.6) ; P=$

0.70

\begin{tabular}{|c|c|c|c|c|c|c|c|c|}
\hline $\begin{array}{l}\text { Kim } \\
2011 \text { (South } \\
\text { Korea) }\end{array}$ & $\begin{array}{l}\text { Multicen- } \\
\text { tre retro- } \\
\text { spective co- } \\
\text { hort/case- } \\
\text { control }\end{array}$ & $\begin{array}{l}\text { ICU/age } \geq 15 \\
\text { years; pres- } \\
\text { ence of criti- } \\
\text { cal illness }\end{array}$ & 107 & 138 & $\begin{array}{l}\text { Mean age (years): no CS } 54.1 \\
( \pm 19.3) ; \text { CS } 56.9( \pm 17.2) \\
\text { Asthma: CS } 9 \% \text {; no CS } 7 \% \\
\text { COPD: CS } 13 \% \text {; no CS } 4 \%\end{array}$ & $\begin{array}{l}\text { Mean (SD) } \\
\text { APACHE } \\
\text { II: no CS } \\
\text { group } 17.5 \\
( \pm 8.5) ; C S \\
\text { group } 21.2 \\
( \pm 7.7) ; P= \\
0.001\end{array}$ & $\begin{array}{l}\text { Dose: median pred equivalent } 75 \\
\mathrm{mg} / \text { day ( } 50 \text { to } 81 \mathrm{mg} / \text { day) } \\
\text { Duration: median days } 6 \text { ( } 3 \text { to } 14 \text { ) }\end{array}$ & $\begin{array}{l}\text { Mortal- } \\
\text { ity (14- } \\
\text { day, 30- } \\
\text { day, and } \\
\text { 90-day), } \\
\text { LOS, ac- } \\
\text { quired } \\
\text { infec- } \\
\text { tions }\end{array}$ \\
\hline $\begin{array}{l}\text { Kinikar } \\
\text { 2012(India) }\end{array}$ & $\begin{array}{l}\text { Single-cen- } \\
\text { tre retro- } \\
\text { spective co- } \\
\text { hort study }\end{array}$ & $\begin{array}{l}\text { ICU/admis- } \\
\text { sions with } \\
\text { influenza, } \\
\text { age }<12 \\
\text { years }\end{array}$ & 21 & 71 & $\begin{array}{l}\text { Cohort median age (years): } \\
2.5 \text { (1.3 to } 6) \\
\text { Asthma: } 4.3 \% \\
\text { Congenital heart disease: } \\
6.5 \%\end{array}$ & $\begin{array}{l}\text { Not re- } \\
\text { ported }\end{array}$ & $\begin{array}{l}\text { Dose: not reported } \\
\text { Timing: not reported } \\
\text { Duration: described as "short } \\
\text { course" }\end{array}$ & $\begin{array}{l}\text { In-hospi- } \\
\text { tal mor- } \\
\text { tality }\end{array}$ \\
\hline $\begin{array}{l}\text { Li } 2012 \text { (Chi- } \\
\text { na - Anhui } \\
\text { province) }\end{array}$ & $\begin{array}{l}\text { Multicentre } \\
\text { retrospec- } \\
\text { tive cohort } \\
\text { study }\end{array}$ & $\begin{array}{l}\text { In-hospi- } \\
\text { tal/preg- } \\
\text { nant, severe } \\
\text { disease }\end{array}$ & 27 & 19 & $\begin{array}{l}\text { Median age (years): adults } \\
\text { who died } 21 \text { (18 to } 31) \text { and } \\
\text { survivors } 21 \text { (18 to } 27)\end{array}$ & $\begin{array}{l}\text { Not re- } \\
\text { ported }\end{array}$ & Not reported & Mortality \\
\hline $\begin{array}{l}\text { Li } 2017 \text { (Chi- } \\
\text { na - main- } \\
\text { land) }\end{array}$ & $\begin{array}{l}\text { Multicentre } \\
\text { retrospec- } \\
\text { tive analysis } \\
\text { of prospec- } \\
\text { tively col- } \\
\text { lected data }\end{array}$ & $\begin{array}{l}\text { In-hospi- } \\
\text { tal/viral } \\
\text { pneumo- } \\
\text { nia, age > } 14 \\
\text { years }\end{array}$ & 1055 & 1086 & $\begin{array}{l}\text { Median age (years): no CS } 33.7 \\
\text { (24.6 to 48.7); CS } 35.0 \text { ( } 23.8 \text { to } \\
52.4 \text { ) } \\
\text { Asthma: no CS } 1.5 \% \text {; CS } 2.1 \% \\
\text { COPD: no CS } 4.3 \% \text {; CS } 5.6 \% \\
\text { Immunosuppression: no CS } \\
\text { 1.4\%; CS } 3.2 \%\end{array}$ & $\begin{array}{l}\mathrm{PaO}_{2} / \mathrm{FiO}_{2} \\
(\mathrm{mmHg}) \text { : } \\
\text { no CS } \\
286.2 \\
(191.7 \text { to } \\
388.2) ; \mathrm{CS} \\
173.3(100 \\
\text { to } 272.4)\end{array}$ & $\begin{array}{l}\text { Dose: median methylpred equiv- } \\
\text { alent } 80 \mathrm{mg} / \text { day ( } 53.3 \text { to } 160 \mathrm{mg} / \\
\text { day); mean methylpred equiva- } \\
\text { lent } 141.3 \text { ( } \pm 142 \text { ) } \\
\text { Duration: median (days) } 7 \text { ( } 4 \text { to } \\
\text { 8); mean (days) } 7.7 \text { ( } \pm 6.8 \text { ) } \\
\text { Timing: median (days) } 6 \text { (4 to } 8 \text { ); } \\
\text { mean (days) } 6.7( \pm 4)\end{array}$ & $\begin{array}{l}\text { Mortal- } \\
\text { ity, ICU } \\
\text { admis- } \\
\text { sion, } \\
\text { hospi- } \\
\text { tal-ac- } \\
\text { quired } \\
\text { infec- } \\
\text { tion, MV }\end{array}$ \\
\hline $\begin{array}{l}\text { Linko } \\
\text { 2011(Fin- } \\
\text { land) }\end{array}$ & $\begin{array}{l}\text { Multicentre } \\
\text { prospective } \\
\text { cohort study }\end{array}$ & $\begin{array}{l}\text { ICU/admis- } \\
\text { sions with } \\
\text { influenza }\end{array}$ & 72 & 60 & $\begin{array}{l}\text { Median age (years): no CS } 44 \\
\text { ( } 25 \text { to } 57 \text { ); CS } 51 \text { ( } 40 \text { to } 56 \text { ) } \\
\text { COPD: no CS } 5 \% \text {; CS } 8 \%\end{array}$ & $\begin{array}{l}\text { Median } \\
\text { SAPS II: } \\
\text { no CS } 22 \\
\text { (15 to } 30)\end{array}$ & $\begin{array}{l}\text { Methylpred and/or hydrocorti- } \\
\text { sone }\end{array}$ & $\begin{array}{l}\text { In-hospi- } \\
\text { tal mor- } \\
\text { tality, } \\
\text { MV, LOS }\end{array}$ \\
\hline
\end{tabular}

$\begin{array}{ll}\text { COPD: no CS 5\%; CS } 8 \% & \text { (15 to } 30)\end{array}$

tality, 


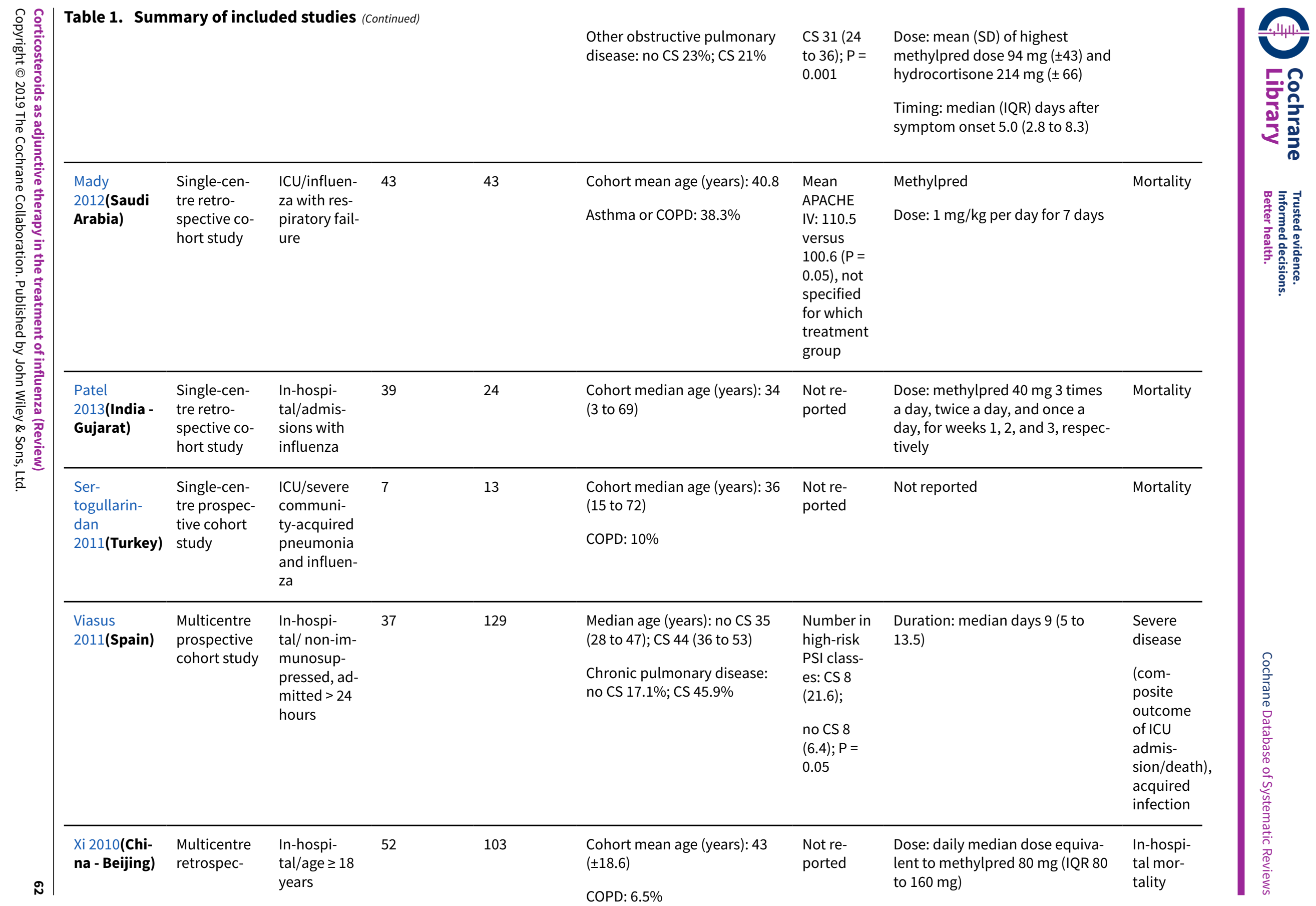




\begin{tabular}{|c|c|c|c|c|c|c|c|c|}
\hline 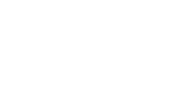 & $\begin{array}{l}\text { tive cohort } \\
\text { study }\end{array}$ & & & & & & & $\begin{array}{l}\text { Sub- } \\
\text { group }\end{array}$ \\
\hline $\begin{array}{l}\text { Yu } \\
2011 \text { a(Chi- } \\
\text { na - } \\
\text { Zhengzhou) }\end{array}$ & $\begin{array}{l}\text { Multicentre } \\
\text { retrospec- } \\
\text { tive cohort } \\
\text { study }\end{array}$ & Not defined & 54 & 74 & $\begin{array}{l}\text { Cohort mean age (years): fe- } \\
\text { males } 28.5( \pm 16.4) \text {; males } 28.5 \\
( \pm 20.4) \\
\text { Range } 8 \text { months to } 79 \text { years }\end{array}$ & $\begin{array}{l}\text { Not re- } \\
\text { ported }\end{array}$ & $\begin{array}{l}\text { Dose: not reported } \\
\text { Duration: mean (days): died } 8.3 \\
\text { ( } \pm 8.0) \text {; survived } 2.6( \pm 4.2) \\
\text { Timing: "Early" }\end{array}$ & Mortality \\
\hline \multicolumn{9}{|c|}{ Avian influenza A(H5N1) } \\
\hline $\begin{array}{l}\text { Liem } \\
\text { 2009(Viet- } \\
\text { nam) }\end{array}$ & $\begin{array}{l}\text { Multicentre } \\
\text { retrospec- } \\
\text { tive cohort }\end{array}$ & $\begin{array}{l}\text { In-hospi- } \\
\text { tal/hospi- } \\
\text { talised pa- } \\
\text { tients with } \\
\text { influenza }\end{array}$ & 29 & 38 & $\begin{array}{l}\text { Cohort median age (years): } 25 \\
\text { (16 to } 42 \text { ) }\end{array}$ & $\begin{array}{l}\text { Not re- } \\
\text { ported }\end{array}$ & $\begin{array}{l}\text { Dose: methylpred } 1 \text { to } 3 \mathrm{mg} / \mathrm{kg} / \\
\text { day for } 7 \text { days }\end{array}$ & $\begin{array}{l}\text { In-hospi- } \\
\text { tal mor- } \\
\text { tality }\end{array}$ \\
\hline \multicolumn{9}{|c|}{ Avian influenza A(H7N9) } \\
\hline $\begin{array}{l}\text { Cao } \\
2016 \text { (China) }\end{array}$ & $\begin{array}{l}\text { Multicentre } \\
\text { retrospec- } \\
\text { tive cohort } \\
\text { study }\end{array}$ & $\begin{array}{l}\text { In-hospi- } \\
\text { tal/age } \geq 14 \\
\text { years with } \\
\text { pneumonia }\end{array}$ & 204 & 84 & $\begin{array}{l}\text { Median age (years): } 58 \text { (IQR } 45 \\
\text { to } 68 \text { ) }\end{array}$ & $\begin{array}{l}\text { Moderate } \\
\text { to severe } \\
\text { ARDS } 207 \\
(71.9)\end{array}$ & $\begin{array}{l}\text { Low-moderate dose: } 168 \text { ( } 82.4 \text { ), } \\
\text { high dose } 36 \text { (17.6). Median dose } \\
\text { (mg/day of methylpred equiva- } \\
\text { lent) } 80 \text { (IQR } 40 \text { to } 120 \text { ) }\end{array}$ & $\begin{array}{l}\text { Mortal- } \\
\text { ity, ad- } \\
\text { verse } \\
\text { events, } \\
\text { viral } \\
\text { shed- } \\
\text { ding }\end{array}$ \\
\hline \multicolumn{9}{|c|}{ Mixed influenza A/B } \\
\hline $\begin{array}{l}\text { Huang } \\
\text { 2017(Tai- } \\
\text { wan) }\end{array}$ & $\begin{array}{l}\text { Single-cen- } \\
\text { tre retro- } \\
\text { spective co- } \\
\text { hort study }\end{array}$ & $\begin{array}{l}\text { In-hospi- } \\
\text { tal/age }>18 \\
\text { years }\end{array}$ & 29 & 19 & $\begin{array}{l}\text { Cohort mean age (years): } 65.9 \\
( \pm 19.2) \\
\text { Chronic pulmonary disease: } \\
\text { respiratory distress cohort } \\
27.1 \%\end{array}$ & $\begin{array}{l}\text { Respirato- } \\
\text { ry distress }\end{array}$ & $\begin{array}{l}\text { Dose and type: not reported } \\
\text { ("Medium to high dose" defined } \\
\text { as } \geq 0.5 \text { to } 2 \mathrm{mg} / \mathrm{kg} / \text { day) } \\
\text { Timing: early (before/within } 72 \\
\text { hours of NAls) } 58.6 \% \\
\text { Duration: short ( } \leq 3 \text { days) } 13.8 \% \text {; } \\
4 \text { to } 13 \text { days } 48.3 \% \text {; } \geq 14 \text { days } \\
34.5 \%\end{array}$ & Mortality \\
\hline
\end{tabular}


Table 1. Summary of included studies (Continued)

\begin{tabular}{|c|c|c|c|c|c|c|c|c|}
\hline $\begin{array}{l}\text { Lee } \\
\text { 2015(China) }\end{array}$ & $\begin{array}{l}\text { Multicentre } \\
\text { retrospec- } \\
\text { tive analysis } \\
\text { of prospec- } \\
\text { tively col- } \\
\text { lected data }\end{array}$ & $\begin{array}{l}\text { In-hospi- } \\
\text { tal/age }>17 \\
\text { years }\end{array}$ & 610 & 2039 & $\begin{array}{l}\text { Cohort median age (years): } 63 \\
\text { ( } 42 \text { to } 79 \text { ) }\end{array}$ & $\begin{array}{l}\text { Ventilato- } \\
\text { ry support } \\
\text { and/or ICU } \\
305 \text { (11.5) }\end{array}$ & Not reported & $\begin{array}{l}\text { Mortali- } \\
\text { ty, bac- } \\
\text { terial su- } \\
\text { perinfec- } \\
\text { tion, LOS }\end{array}$ \\
\hline $\begin{array}{l}\text { Moreno } \\
\text { 2018(Spain) }\end{array}$ & $\begin{array}{l}\text { Multicentre } \\
\text { prospective } \\
\text { cohort study }\end{array}$ & $\begin{array}{l}\text { ICU/viral } \\
\text { pneumonia }\end{array}$ & 604 & 1242 & $\begin{array}{l}\text { Median age (years): CS } 53 \text { ( } 41 \\
\text { to } 62) ; \text { no CS } 51 \text { ( } 39 \text { to } 61 \text { ) }\end{array}$ & $\begin{array}{l}\text { Median } \\
\text { APACHE } \\
\text { II score: } \\
\text { CS group } \\
15 \text { (10 to } \\
20) \text {; no CS } \\
\text { group } 14 \\
\text { (10 to 19); } \\
P<0.0001\end{array}$ & $\begin{array}{l}\text { Median daily dose methylpred } \\
\text { equivalent } 80 \mathrm{mg} \text { ( } 60 \text { to } 120 \mathrm{mg} \text { ) } \\
\text { Median duration (days) } 7 \text { (5 to } 10 \text { ) } \\
\text { Administered within } 24 \text { hours of } \\
\text { ICU admission }\end{array}$ & $\begin{array}{l}\text { ICU mor- } \\
\text { tality }\end{array}$ \\
\hline $\begin{array}{l}\text { Sheu } \\
\text { 2017(Tai- } \\
\text { wan) }\end{array}$ & $\begin{array}{l}\text { Multicentre } \\
\text { retrospec- } \\
\text { tive cohort } \\
\text { study }\end{array}$ & $\begin{array}{l}\text { ICU admis- } \\
\text { sions with } \\
\text { confirmed } \\
\text { influenza }\end{array}$ & 101 & 91 & Cohort mean age (years): 58.3 & $\begin{array}{l}\text { ARDS: } \\
\text { Mild } 8.3 \% \text {; } \\
\text { moder- } \\
\text { ate } 29.2 \% \text {; } \\
\text { severe } \\
62.5 \%\end{array}$ & Not reported & Mortality \\
\hline
\end{tabular}

Studies not included in meta-analysis

Influenza 2009 influenza A H1N1 virus (H1N1pdm09)

\begin{tabular}{|c|c|c|c|c|c|c|c|c|}
\hline $\begin{array}{l}\text { Delgado-Ro- } \\
\text { driguez } \\
\text { 2012(Spain) }\end{array}$ & $\begin{array}{l}\text { Multicentre } \\
\text { prospective } \\
\text { cohort }\end{array}$ & $\begin{array}{l}\text { In-hos- } \\
\text { pital/ILI, } \\
\text { RTI, septic } \\
\text { shock, mul- } \\
\text { ti-organ fail- } \\
\text { ure }\end{array}$ & 31 & 782 & $\begin{array}{l}\text { Cohort median age (years): } 41 \\
\text { (19 to } 55)\end{array}$ & $\begin{array}{l}\text { Not re- } \\
\text { ported }\end{array}$ & $\begin{array}{l}\text { Corticosteroid use } 90 \text { days prior } \\
\text { to admission }\end{array}$ & $\begin{array}{l}\text { Poor } \\
\text { outcome } \\
\text { (ICU ad- } \\
\text { mission } \\
\text { and in- } \\
\text { hospital } \\
\text { death), } \\
\text { LOS }\end{array}$ \\
\hline
\end{tabular}




\begin{tabular}{|c|c|c|c|c|c|c|c|c|c|c|}
\hline \multirow{7}{*}{ 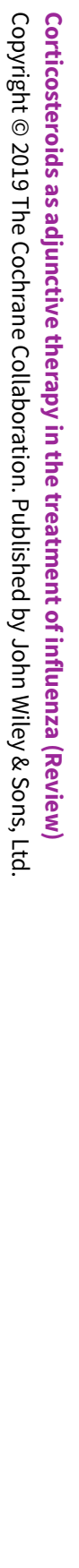 } & \multicolumn{9}{|c|}{ Immary of inc } & \multirow{3}{*}{ 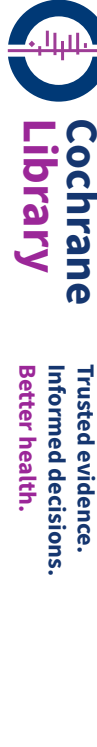 } \\
\hline & $\begin{array}{l}\text { Jain } \\
2009 \text { (USA) }\end{array}$ & $\begin{array}{l}\text { Multicentre } \\
\text { retrospec- } \\
\text { tive cohort }\end{array}$ & $\begin{array}{l}\text { In-hospi- } \\
\text { tal/ILI with } \\
\text { hospital ad- } \\
\text { mission } \geq 24 \\
\text { hours }\end{array}$ & 86 & 153 & $\begin{array}{l}\text { Cohort median age: } 21 \text { years } \\
\text { (21 days to } 86 \text { years) } \\
\text { Asthma: } 28 \% \\
\text { COPD: } 8 \% \text { Immunosuppres- } \\
\text { sion: } 15 \%\end{array}$ & $\begin{array}{l}\text { Not re- } \\
\text { ported }\end{array}$ & Not reported & $\begin{array}{l}\text { Death/ } \\
\text { ICU ad- } \\
\text { mis- } \\
\text { sion ver- } \\
\text { sus sur- } \\
\text { vival/no } \\
\text { ICU ad- } \\
\text { mission }\end{array}$ & \\
\hline & $\begin{array}{l}\text { Kudo } \\
\text { 2012(Japan) }\end{array}$ & $\begin{array}{l}\text { Single-cen- } \\
\text { tre retro- } \\
\text { spective co- } \\
\text { hort }\end{array}$ & $\begin{array}{l}\text { In-hospi- } \\
\text { tal/hospi- } \\
\text { talised pa- } \\
\text { tients with } \\
\text { respiratory } \\
\text { disorders }\end{array}$ & 46 & 12 & $\begin{array}{l}\text { Cohort median age (years): } 8 \\
\text { ( } 0 \text { to } 71 \text { ) } \\
\text { Asthma: } 29.2 \%\end{array}$ & $\begin{array}{l}\text { Not re- } \\
\text { ported }\end{array}$ & $\begin{array}{l}\text { Dose: methylpred } 1 \text { to } 1.5 \mathrm{mg} / \mathrm{kg} \text {, } \\
2 \text { to } 4 \text { times/day } \\
\text { Duration: median } 5.1 \text { days } \\
\text { Timing: median } 2.1 \text { days follow- } \\
\text { ing symptom onset }\end{array}$ & LOS & \\
\hline & Interpandemic & c (seasonal) in & luenza & & & & & & & \\
\hline & $\begin{array}{l}\text { Boudreault } \\
\text { 2011(USA) }\end{array}$ & $\begin{array}{l}\text { Single-cen- } \\
\text { tre retro- } \\
\text { spective co- } \\
\text { hort }\end{array}$ & $\begin{array}{l}\text { Non-ICU/ } \\
\text { HSCT recip- } \\
\text { ients with } \\
\text { RTI }\end{array}$ & $\begin{array}{l}80 \\
\text { (low dose } \\
43 \text { and high } \\
\text { dose } 37 \text { ) }\end{array}$ & 63 & $\begin{array}{l}\text { Median age (years): no CS } 42 \\
\text { ( } 32 \text { to } 51 \text { ); low-dose CS } 42 \text { ( } 28 \\
\text { to } 53 \text { ); high-dose CS } 40 \text { ( } 32 \text { to } \\
54 \text { ) }\end{array}$ & $\begin{array}{l}\text { Not re- } \\
\text { ported }\end{array}$ & $\begin{array}{l}\text { Highest dose in 2/52 preced- } \\
\text { ing influenza Low dose (pred/ } \\
\text { methylpred < } 1 \mathrm{mg} / \mathrm{kg} / \text { day); high } \\
\text { dose (pred/methylpred >= } 1 \mathrm{mg} / \\
\mathrm{kg} / \text { day) }\end{array}$ & $\begin{array}{l}\text { MV, time } \\
\text { to death, } \\
\text { PVS }\end{array}$ & \\
\hline & $\begin{array}{l}\text { Ono } 2016 \\
\text { (Japan) }\end{array}$ & $\begin{array}{l}\text { Multicentre } \\
\text { retrospec- } \\
\text { tive cohort } \\
\text { study }\end{array}$ & $\begin{array}{l}\text { Medical in- } \\
\text { surance } \\
\text { database, } \\
<65 \text { years, } \\
\text { first episode } \\
\text { of hospitali- } \\
\text { sation with } \\
\text { confirmed } \\
\text { influenza }\end{array}$ & 804 & 87,250 & $\begin{array}{l}\text { All< } 65 \text { years } \\
\text { Asthma: hospitalised } 39.5 \% \text {; } \\
\text { non-hospitalised } 23.5 \% \\
\text { COPD: hospitalised } 2.9 \% \text {; } \\
\text { non-hospitalised } 0.5 \% \\
\text { Immunosuppression: hos- } \\
\text { pitalised } 0.36 \% \text {; non-hospi- } \\
\text { talised } 0.13 \%\end{array}$ & $\begin{array}{l}\text { Not re- } \\
\text { ported }\end{array}$ & $\begin{array}{l}\text { Dose not reported. } \\
\text { Timing: > } 30 \text { days steroid use in 6- } \\
\text { month baseline prior to influenza } \\
\text { diagnosis }\end{array}$ & $\begin{array}{l}\text { Rate of } \\
\text { hospital- } \\
\text { isation }\end{array}$ & 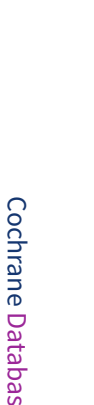 \\
\hline & $\begin{array}{l}\text { Wirz } \\
\text { 2016(Switzer- } \\
\text { land) }\end{array}$ & $\begin{array}{l}\text { Multicentre } \\
\text { randomised } \\
\text { controlled } \\
\text { trial of ad- } \\
\text { junctive } \\
\text { prednisone }\end{array}$ & $\begin{array}{l}\text { Non-ICU } \\
\text { with com- } \\
\text { munity-ac- } \\
\text { quired } \\
\text { pneumonia } \\
\text { (influenza }\end{array}$ & 11 & 13 & $\begin{array}{l}\text { All trial participants: mean } \\
\text { age (years): CS arm } 70.3 \\
( \pm 17.5) ; \text { placebo arm } 69.0 \\
( \pm 17)\end{array}$ & $\begin{array}{l}\text { PSI mean } \\
\text { score: } \\
\text { CS } 92.5 \\
( \pm 38.2) \\
\text { place- }\end{array}$ & $\begin{array}{l}\text { Dose: oral prednisone } 50 \mathrm{mg} / \text { day } \\
\text { Duration: } 7 \text { days } \\
\text { Timing: early }\end{array}$ & $\begin{array}{l}\text { Any- } \\
\text { cause } \\
\text { mortali- } \\
\text { ty at } 30 \\
\text { days, } \\
\text { hospital }\end{array}$ & 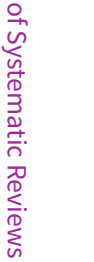 \\
\hline
\end{tabular}




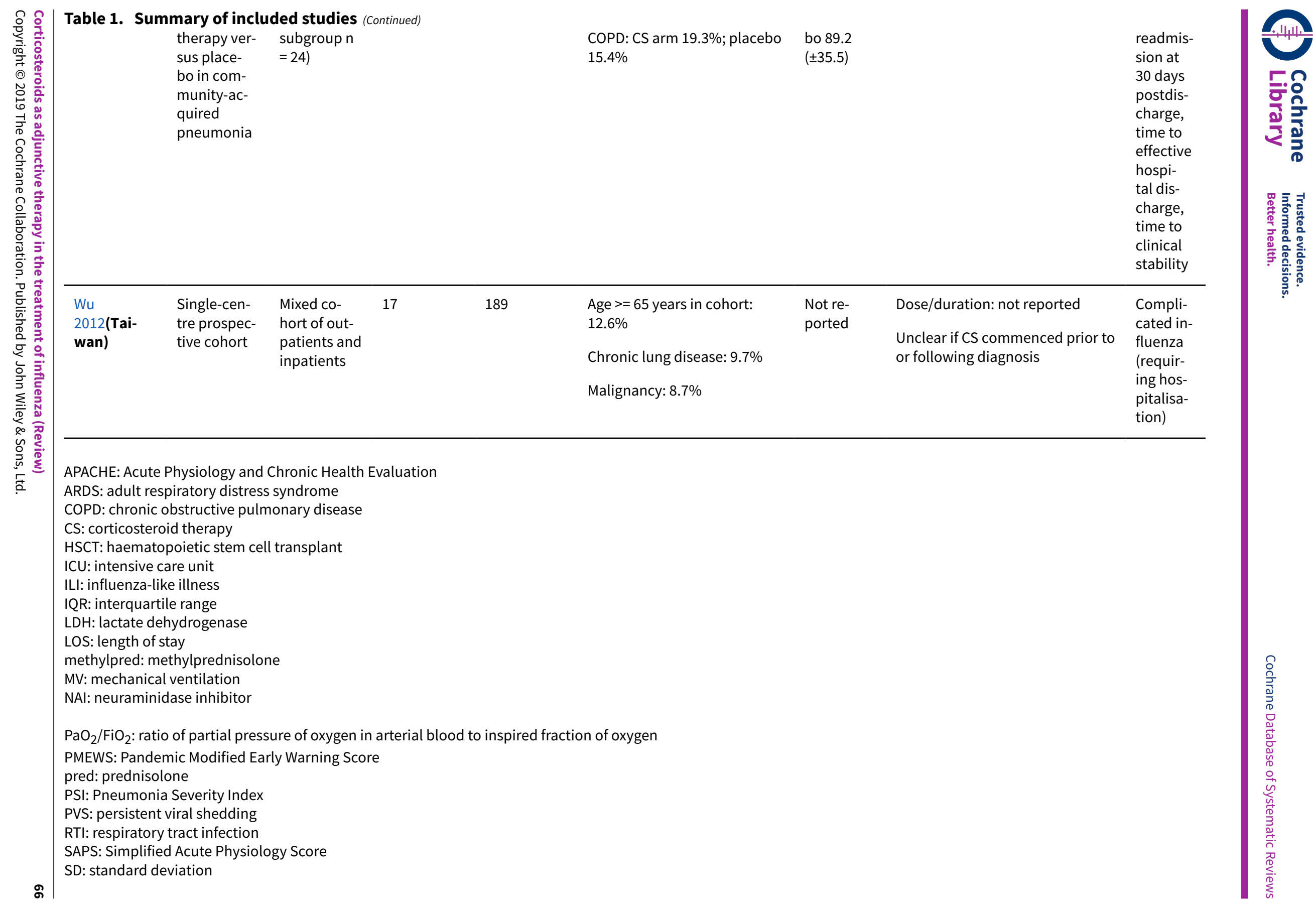



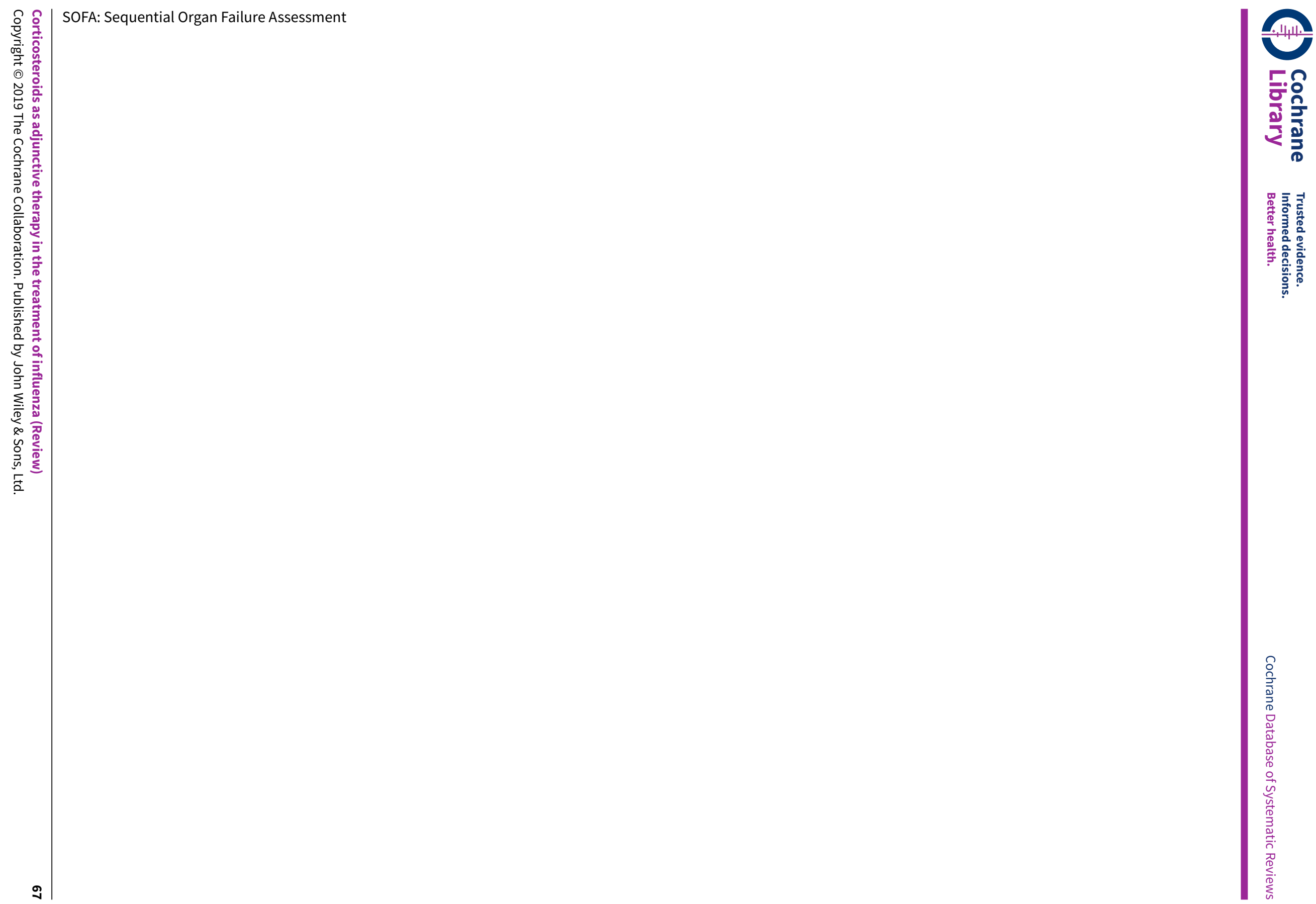
Table 2. Risk of bias in observational studies using the Newcastle-Ottawa Scale

\begin{tabular}{|c|c|c|c|c|}
\hline Study & Outcome & $\begin{array}{l}\begin{array}{l}\text { Selection } \\
\text { domain }\end{array} \\
\text { (maxi- } \\
\text { mum } 4 \\
\text { stars) }\end{array}$ & $\begin{array}{l}\text { Compara- } \\
\text { bility do- } \\
\text { main } \\
\text { (maxi- } \\
\text { mum } 2 \\
\text { stars) }\end{array}$ & $\begin{array}{l}\text { Outcome } \\
\text { domain } \\
\text { (maxi- } \\
\text { mum } 3 \\
\text { stars) }\end{array}$ \\
\hline Al-Busaidi 2016 & Length of stay & 3 & 1 & 2 \\
\hline Balaganesakumar 2013 & Mortality & 2 & 1 & 2 \\
\hline Boudreault $2011 \dagger$ & Time to death & 2 & 1 & 2 \\
\hline Brun-Buisson 2011 & In-hospital mortality & 3 & 2 & 3 \\
\hline Brun-Buisson 2011 & Length of ICU stay & 3 & 0 & 3 \\
\hline Brun-Buisson 2011 & ICU-acquired infection & 3 & 0 & 3 \\
\hline Cao 2016 & Mortality & 4 & 2 & 3 \\
\hline Cao 2016 & Hospital-acquired infection & 4 & 2 & 2 \\
\hline Cao 2016 & Viral shedding & 4 & 2 & 2 \\
\hline Chawla 2013 & Mortality & 3 & 0 & 3 \\
\hline Delaney 2016 & Mortality & 4 & 2 & 3 \\
\hline Delaney 2016 & ICU-acquired infection & 4 & 0 & 3 \\
\hline Delgado-Rodriguez $2012 †$ & $\begin{array}{l}\text { Composite outcome of ICU admission and mor- } \\
\text { tality }\end{array}$ & 3 & 2 & 3 \\
\hline $\operatorname{Han} 2011 \dagger$ & Critical illness & 3 & 2 & 3 \\
\hline Jain $2009 \dagger$ & $\begin{array}{l}\text { ICU admission death versus survival/no ICU ad- } \\
\text { mission }\end{array}$ & 4 & 0 & 3 \\
\hline Huang 2017 & Mortality & 2 & 0 & 2 \\
\hline Kim 2011 & Mortality & 4 & 2 & 3 \\
\hline Kim 2011 & MV & 4 & 0 & 3 \\
\hline Kim 2011 & LOS & 4 & 0 & 3 \\
\hline Kim 2011 & Hospital-acquired infection & 4 & 0 & 3 \\
\hline Kinikar 2012 & In-hospital mortality & 3 & 0 & 3 \\
\hline Kudo $2012 \dagger$ & LOS & 4 & 0 & 2 \\
\hline Lee 2015 & Mortality & 4 & 2 & 3 \\
\hline
\end{tabular}


Table 2. Risk of bias in observational studies using the Newcastle-Ottawa Scale (Continued)

\begin{tabular}{|c|c|c|c|c|}
\hline Lee 2015 & Hospital-acquired infection & 4 & 0 & 3 \\
\hline Lee 2015 & LOS & 4 & 2 & 3 \\
\hline Li 2012 & Mortality & 2 & 0 & 3 \\
\hline Li 2017 & Mortality & 4 & 2 & 3 \\
\hline Li 2017 & ICU admission & 4 & 0 & 3 \\
\hline Li 2017 & Hospital-acquired infection & 4 & 0 & 2 \\
\hline Li 2017 & MV & 4 & 0 & 3 \\
\hline Liem 2009 & In-hospital mortality & 4 & 1 & 3 \\
\hline Linko 2011 & In-hospital mortality & 4 & 2 & 3 \\
\hline Linko 2011 & MV & 4 & 0 & 3 \\
\hline Linko 2011 & LOS & 4 & 0 & 3 \\
\hline Mady 2012 & Mortality & 3 & 0 & 3 \\
\hline Moreno 2018 & ICU mortality & 4 & 2 & 3 \\
\hline Moreno 2018 & ICU LOS & 4 & 0 & 2 \\
\hline Moreno 2018 & MV & 4 & 1 & 3 \\
\hline Ono $2016 \dagger$ & Hospitalisation & 2 & 2 & 3 \\
\hline Patel 2013 & Mortality & 2 & 0 & 3 \\
\hline Sertogullarindan 2011 & Mortality & 3 & 0 & 3 \\
\hline Viasus 2011 & In-hospital mortality & 4 & 0 & 3 \\
\hline Viasus 2011 & Hospital-acquired infection & 4 & 0 & 3 \\
\hline Wu $2012 \dagger$ & Influenza requiring hospitalisation & 4 & 1 & 3 \\
\hline Xi 2010 & In-hospital mortality & 3 & 1 & 3 \\
\hline Yu 2011a & Mortality & 2 & 1 & 1 \\
\hline
\end{tabular}

ICU: intensive care unit

LOS: length of stay

MV: mechanical ventilation

† Studies not included in meta-analysis (four studies investigating corticosteroid therapy before influenza diagnosis (Boudreault 2011; Delgado-Rodriguez 2012; Ono 2016; Wu 2012); three studies with no mortality data according to corticosteroid use (Han 2011; Jain 2009; Kudo 2012)). 
Table 3. Summary of studies reporting mortality

\begin{tabular}{|c|c|c|c|c|c|c|}
\hline Study & Outcome reported & $\begin{array}{l}\text { Mor- } \\
\text { tality } \\
\text { in CS } \\
\text { treat- } \\
\text { ment } \\
\text { group }\end{array}$ & $\begin{array}{l}\text { Mortal- } \\
\text { ity in } \\
\text { group } \\
\text { not } \\
\text { treat- } \\
\text { ed } \\
\text { with } \\
\text { CS }\end{array}$ & $\begin{array}{l}\text { Reported unadjust- } \\
\text { ed risk of mortality }\end{array}$ & $\begin{array}{l}\text { Reported ad- } \\
\text { justed risk of } \\
\text { mortality }\end{array}$ & $\begin{array}{l}\text { Variables included in model for } \\
\text { adjusted estimates }\end{array}$ \\
\hline $\begin{array}{l}\text { Bala- } \\
\text { gane- } \\
\text { saku- } \\
\text { mar } \\
2013\end{array}$ & Mortality & $\begin{array}{l}50 / 70 \\
(71.4)\end{array}$ & $\begin{array}{l}20 / 210 \\
(9.5)\end{array}$ & $\begin{array}{l}\text { OR } 23.8(95 \% \text { Cl } 11.3 \\
\text { to } 50.8)\end{array}$ & Not reported & - \\
\hline $\begin{array}{l}\text { Brun- } \\
\text { Buis- } \\
\text { son } \\
2011\end{array}$ & $\begin{array}{l}\text { In-hospital mortali- } \\
\text { ty }\end{array}$ & $\begin{array}{l}28 / 83 \\
(33.8)\end{array}$ & $\begin{array}{l}21 / 125 \\
(16.8)\end{array}$ & $\begin{array}{l}\text { HR } 2.39(95 \% \text { Cl } 1.32 \\
\text { to } 4.31)\end{array}$ & $\begin{array}{l}\text { aHR } 2.59(95 \% \mathrm{Cl} \\
1.42 \text { to } 4.73)\end{array}$ & $\begin{array}{l}\text { Immunosuppression, disease } \\
\text { severity (SAPS III), vasopressor } \\
\text { use }\end{array}$ \\
\hline $\begin{array}{l}\text { Cao } \\
2016\end{array}$ & $\begin{array}{l}\text { 30-day mortality } \\
\text { (also adjusted esti- } \\
\text { mates provided for } \\
60 \text {-day mortality }\end{array}$ & $\begin{array}{l}81 / 204 \\
(39.7)\end{array}$ & $\begin{array}{l}11 / 84 \\
(13.1)\end{array}$ & Not reported & $\begin{array}{l}\text { aHR } 1.81(95 \% \mathrm{Cl} \\
0.88 \text { to } 3.74)\end{array}$ & $\begin{array}{l}\text { Age, underlying comorbidities, } \\
\text { laboratory findings, } \mathrm{PaO}_{2} / \mathrm{FiO}_{2} \text {, } \\
\text { shock, antibiotics, } \mathrm{NAl} \text { treatment }\end{array}$ \\
\hline $\begin{array}{l}\text { Chawla } \\
2013\end{array}$ & Mortality & $\begin{array}{l}9 / 38 \\
(23.7)\end{array}$ & $\begin{array}{l}1 / 39 \\
(2.6)\end{array}$ & $\begin{array}{l}\text { OR } 11.8(95 \% \mathrm{Cl} 1.4 \\
\text { to } 98.4)\end{array}$ & Not reported & - \\
\hline $\begin{array}{l}\text { De- } \\
\text { laney } \\
2016\end{array}$ & $\begin{array}{l}\text { In-hospital mortali- } \\
\text { ty }\end{array}$ & $\begin{array}{l}70 / 280 \\
(25.0)\end{array}$ & $\begin{array}{l}51 / 324 \\
(15.7)\end{array}$ & OR 1.82 (1.21 to 2.74$)$ & $\begin{array}{l}\text { aOR } 1.85(95 \% \mathrm{Cl} \\
1.12 \text { to } 3.04)\end{array}$ & $\begin{array}{l}\text { Age, sex, disease severity, comor- } \\
\text { bid illness, bacterial co-infection } \\
\text { at admission }\end{array}$ \\
\hline $\begin{array}{l}\text { Huang } \\
2017\end{array}$ & Mortality & $\begin{array}{l}9 / 29 \\
(31.0)\end{array}$ & $\begin{array}{l}5 / 19 \\
(26.3)\end{array}$ & $\begin{array}{l}\text { OR } 1.26(95 \% \mathrm{Cl} 0.35 \\
\text { to } 4.57)\end{array}$ & Not reported & $\mathrm{N} / \mathrm{A}$ \\
\hline $\begin{array}{l}\text { Kim } \\
2011\end{array}$ & $\begin{array}{l}\text { 90-day mortality } \\
\text { (also unadjusted } \\
\text { estimates provided } \\
\text { for 14-day and } 30 \text { - } \\
\text { day mortality) }\end{array}$ & $\begin{array}{l}62 / 107 \\
(57.9)\end{array}$ & $\begin{array}{l}37 / 138 \\
(26.8)\end{array}$ & $\begin{array}{l}\text { OR } 3.76(95 \% \text { Cl } 2.19 \\
\text { to } 6.44)\end{array}$ & $\begin{array}{l}\text { aOR } 2.20(95 \% \mathrm{Cl} \\
1.03 \text { to } 4.71)\end{array}$ & $\begin{array}{l}\text { Age, disease severity (SOFA), MV, } \\
\text { lymphocyte count, propensity } \\
\text { score) }\end{array}$ \\
\hline $\begin{array}{l}\text { Kinikar } \\
2012\end{array}$ & $\begin{array}{l}\text { In-hospital mortali- } \\
\text { ty }\end{array}$ & $\begin{array}{l}9 / 21 \\
(42.8)\end{array}$ & $\begin{array}{l}6 / 71 \\
(8.4)\end{array}$ & $\begin{array}{l}\text { OR } 8.12(95 \% \mathrm{Cl} 2.44 \\
\text { to } 27.05)\end{array}$ & Not reported & $\mathrm{N} / \mathrm{A}$ \\
\hline $\begin{array}{l}\text { Lee } \\
2015\end{array}$ & $\begin{array}{l}\text { 30-day mortality } \\
\text { (also adjusted esti- } \\
\text { mates provided for } \\
60 \text {-day mortality) }\end{array}$ & $\begin{array}{l}60 / 600 \\
(10.0)\end{array}$ & $\begin{array}{l}96 / 2049 \\
(4.7)\end{array}$ & Not reported & $\begin{array}{l}\text { aHR } 1.73(95 \% \mathrm{Cl} \\
1.14 \text { to } 2.62)\end{array}$ & $\begin{array}{l}\text { Age, sex, NAI propensity, bacteri- } \\
\text { al superinfection, statins, influen- } \\
\text { za subtype }\end{array}$ \\
\hline $\begin{array}{l}\mathrm{Li} \\
2012\end{array}$ & Mortality & $\begin{array}{l}6 / 27 \\
(22.2)\end{array}$ & $\begin{array}{l}1 / 19 \\
(5.2)\end{array}$ & $\begin{array}{l}\text { OR } 5.14(95 \% \mathrm{Cl} 0.56 \\
\text { to } 46.82)\end{array}$ & Not reported & $\mathrm{N} / \mathrm{A}$ \\
\hline $\begin{array}{l}\mathrm{Li} \\
2017\end{array}$ & 30-day mortality & $\begin{array}{l}232 / 1055 \\
(22.0)\end{array}$ & $\begin{array}{l}74 / 1086 \\
(6.8)\end{array}$ & $\begin{array}{l}\text { OR } 3.86(95 \% \text { Cl } 2.92 \\
\text { to } 5.09)\end{array}$ & $\begin{array}{l}\text { aHR } 0.80(95 \% \mathrm{Cl} \\
0.56 \text { to } 1.15)\end{array}$ & $\begin{array}{l}\text { Age, underlying comorbidities, } \\
\text { disease severity, NAI treatment, } \\
\text { propensity scores }\end{array}$ \\
\hline $\begin{array}{l}\text { Liem } \\
2009\end{array}$ & $\begin{array}{l}\text { In-hospital mortali- } \\
\text { ty }\end{array}$ & $\begin{array}{l}17 / 29 \\
(58.6)\end{array}$ & $\begin{array}{l}9 / 38 \\
(23.7)\end{array}$ & $\begin{array}{l}\text { OR } 4.25(95 \% \mathrm{Cl} 1.48 \\
\text { to } 12.22)\end{array}$ & $\begin{array}{l}\text { aOR } 4.11(95 \% \mathrm{Cl} \\
1.14 \text { to } 14.83)\end{array}$ & $\begin{array}{l}\text { Neutropenia as surrogate for } \\
\text { severity }\end{array}$ \\
\hline
\end{tabular}


Table 3. Summary of studies reporting mortality (Continued)

\begin{tabular}{|c|c|c|c|c|c|c|}
\hline $\begin{array}{l}\text { Linko } \\
2011\end{array}$ & $\begin{array}{l}\text { In-hospital mortali- } \\
\text { ty }\end{array}$ & $\begin{array}{l}8 / 72 \\
(11.1)\end{array}$ & $\begin{array}{l}2 / 60 \\
(3.3)\end{array}$ & $\begin{array}{l}\text { OR } 3.63(95 \% \mathrm{Cl} 0.74 \\
\text { to } 17.77)\end{array}$ & $\begin{array}{l}\text { aOR } 3.3(95 \% \mathrm{Cl} \\
0.5 \text { to } 23.4)\end{array}$ & Disease severity (SAPS II) \\
\hline $\begin{array}{l}\text { Mady } \\
2012\end{array}$ & $\begin{array}{l}\text { In-hospital mortali- } \\
\text { ty }\end{array}$ & $\begin{array}{l}20 / 43 \\
(46.5)\end{array}$ & $\begin{array}{l}10 / 43 \\
(23.2)\end{array}$ & $\begin{array}{l}\text { OR } 2.87(95 \% \mathrm{Cl} 1.14 \\
\text { to } 7.25)\end{array}$ & Not reported & $\mathrm{N} / \mathrm{A}$ \\
\hline $\begin{array}{l}\text { Moreno I } \\
2018\end{array}$ & ICU mortality & $\begin{array}{l}166 / 604 \\
(27.5)\end{array}$ & $\begin{array}{l}234 / 1242 \\
(18.8)\end{array}$ & $\begin{array}{l}\text { OR } 1.6(95 \% \mathrm{Cl} 1.3 \text { to } \\
2.0)\end{array}$ & $\begin{array}{l}\text { aHR } 1.32(95 \% \mathrm{Cl} \\
1.08 \text { to } 1.60)\end{array}$ & $\begin{array}{l}\text { Propensity matched, APACHE II, } \\
\text { gap ICU, number infiltrates on } \\
\text { chest x-ray, laboratory parame- } \\
\text { ters, comorbidities, pregnancy, } \\
\text { MV, non-invasive MV failure, ven- } \\
\text { tilator-associated pneumonia }\end{array}$ \\
\hline $\begin{array}{l}\text { Patel } \\
2013\end{array}$ & Mortality & $\begin{array}{l}11 / 39 \\
(28.2)\end{array}$ & $\begin{array}{l}3 / 24 \\
(12.5)\end{array}$ & $\begin{array}{l}\text { OR } 2.75(95 \% \mathrm{Cl} 0.68 \\
\text { to } 11.1)\end{array}$ & Not reported & - \\
\hline $\begin{array}{l}\text { Ser- } \\
\text { togullarin } \\
\text { dan } \\
2011\end{array}$ & Mortality & $\begin{array}{l}4 / 7 \\
(57.1)\end{array}$ & $\begin{array}{l}5 / 13 \\
(34.5)\end{array}$ & $\begin{array}{l}\text { OR } 2.13(95 \% \mathrm{Cl} 0.33 \\
\text { to } 13.81)\end{array}$ & Not reported & $\mathrm{N} / \mathrm{A}$ \\
\hline $\begin{array}{l}\text { Sheu } \\
2017\end{array}$ & Mortality & $\begin{array}{l}\text { Not re- } \\
\text { ported }\end{array}$ & $\begin{array}{l}\text { Not re- } \\
\text { ported }\end{array}$ & Not reported & $\begin{array}{l}\text { aHR } 1.81(95 \% \mathrm{Cl} \\
1.04 \text { to } 3.14)\end{array}$ & $\begin{array}{l}\text { Age, sex, APACHE II score, ARDS } \\
\text { severity }\end{array}$ \\
\hline $\begin{array}{l}\text { Viasus } \\
2011\end{array}$ & $\begin{array}{l}\text { Mortality (primary } \\
\text { outcome was "se- } \\
\text { vere disease" = ICU } \\
\text { admission/death) }\end{array}$ & $\begin{array}{l}3 / 37 \\
(8.1)\end{array}$ & $\begin{array}{l}4 / 129 \\
(3.1)\end{array}$ & $\begin{array}{l}\text { OR } 2.76(95 \% \mathrm{Cl} 0.59 \\
\text { to } 12.92)\end{array}$ & Not reported & $\mathrm{N} / \mathrm{A}$ \\
\hline $\begin{array}{l}X i \\
2010\end{array}$ & $\begin{array}{l}\text { In-hospital mortali- } \\
\text { ty }\end{array}$ & $\begin{array}{l}17 / 52 \\
(32.7)\end{array}$ & $\begin{array}{l}10 / 103 \\
(9.7)\end{array}$ & $\begin{array}{l}\text { OR } 4.52(95 \% \mathrm{Cl} 1.89 \\
\text { to } 10.81)\end{array}$ & $\begin{array}{l}\text { aOR } 3.67(95 \% \mathrm{Cl} \\
0.99 \text { to } 13.64)\end{array}$ & $\begin{array}{l}\text { Ethnicity, comorbid illness, } \\
\text { symptoms at onset, laboratory } \\
\text { tests }\end{array}$ \\
\hline $\begin{array}{l}\text { Wirz } \\
2016\end{array}$ & 30-day mortality & $\begin{array}{l}1 / 11 \\
(9.1)\end{array}$ & $\begin{array}{l}1 / 13 \\
(7.7)\end{array}$ & $\begin{array}{l}\text { OR } 1.2(95 \% \mathrm{Cl} 0.07 \\
\text { to } 21.72)\end{array}$ & $\begin{array}{l}\text { aOR } 0.13(95 \% \mathrm{Cl} \\
\text { not reported) }\end{array}$ & $\begin{array}{l}\text { Age, Pneumonia Severity Index, } \\
\text { comorbidities }\end{array}$ \\
\hline $\begin{array}{l}\text { Yu } \\
2011 a\end{array}$ & Mortality & $\begin{array}{l}14 / 54 \\
(25.9)\end{array}$ & $\begin{array}{l}4 / 74 \\
(5.4)\end{array}$ & $\begin{array}{l}\text { OR } 6.12(95 \% \mathrm{Cl} 1.89 \\
\text { to } 19.88)\end{array}$ & Not reported & $\mathrm{N} / \mathrm{A}$ \\
\hline
\end{tabular}

aHR: adjusted hazard ratio

aOR: adjusted odds ratio

APACHE: Acute Physiology and Chronic Health Evaluation

ARDS: adult respiratory distress syndrome

$\mathrm{Cl}$ : confidence interval

CS: corticosteroid

HR: hazard ratio

ICU: intensive care unit

MV: mechanical ventilation

NAl: neuraminidase inhibitor

OR: odds ratio

$\mathrm{PaO}_{2} / \mathrm{FiO}_{2}$ : ratio of partial pressure of oxygen in arterial blood to inspired fraction of oxygen

SAPS: Simplified Acute Physiology Score

SOFA: Sequential Organ Failure Assessment 
Table 4. Summary of studies reporting outcomes stratified according to different corticosteroid regimens

\begin{tabular}{|c|c|c|c|}
\hline $\begin{array}{l}\text { Subgroup } \\
\text { analysis }\end{array}$ & Study & Outcome & Comments \\
\hline $\begin{array}{l}\text { Early and late } \\
\text { CS therapy } \\
\text { compared with } \\
\text { no CS therapy }\end{array}$ & $\begin{array}{l}\text { Brun-Buisson } \\
2011\end{array}$ & $\begin{array}{l}\text { Hospital mortality } \\
\text { Early CS: HR } 3.42,95 \% \mathrm{Cl} 1.73 \text { to } 6.75 ; \mathrm{P}=0.001 \\
\text { Late CS: HR } 1.93,95 \% \mathrm{Cl} 0.84 \text { to } 4.43 ; \mathrm{P}=0.12\end{array}$ & $\begin{array}{l}\text { Early treatment defined as "within } 3 \text { days } \\
\text { of mechanical ventilation". } \\
\text { Propensity score adjusted analysis }\end{array}$ \\
\hline $\begin{array}{l}\text { Early CS thera- } \\
\text { py versus late/ } \\
\text { no CS therapy } \\
\text { groups com- } \\
\text { bined }\end{array}$ & Han 2011 & $\begin{array}{l}\text { Critical illness } \\
\text { RR } 1.8,95 \% \mathrm{Cl} 1.2 \text { to } 2.8\end{array}$ & $\begin{array}{l}\text { Early treatment defined as }<72 \text { hours } \\
\text { from influenza-like illness. } \\
\text { Multivariate analysis following adjust- } \\
\text { ment for underlying comorbid illnesses, } \\
\text { age, pregnancy, and obesity }\end{array}$ \\
\hline
\end{tabular}

\begin{tabular}{|c|c|c|}
\hline $\begin{array}{l}\text { Low-dose ver- } \\
\text { sus high-dose }\end{array}$ & Xi 2010 & In-hospital mortality \\
\hline CS therapy & & $9 / 30$ versus $8 / 22, P=0.854$ \\
\hline
\end{tabular}

Low-dose CS therapy defined as $\leq 80 \mathrm{mg}$ methylprednisolone or equivalent daily dose.

Unadjusted outcome

\begin{tabular}{|c|c|c|c|}
\hline $\begin{array}{l}\text { Low-moder- } \\
\text { ate-dose and } \\
\text { high-dose CS }\end{array}$ & Cao 2016 & $\begin{array}{l}\text { 30-day mortality } \\
\text { Low-moderate-dose CS: HR 1.64, 95\% Cl } 0.79 \text { to }\end{array}$ & $\begin{array}{l}\text { Low-moderate-dose CS therapy defined } \\
\text { as } 25 \text { to } 150 \mathrm{mg} / \text { day methylprednisolone } \\
\text { or equivalent. }\end{array}$ \\
\hline
\end{tabular}

therapy com-

pared with no

CS therapy

3.39; $P=0.183$

High-dose CS: HR 3.05, 95\% Cl 1.28 to $7.25 ; \mathrm{P}=$ 0.012
High-dose CS therapy defined as $>150$ $\mathrm{mg} /$ day methylprednisolone or equivalent.

\section{Adjusted outcome}

Low-moder-
ate-dose and
high-dose CS
therapy com-
pared with no
CS therapy

Cao 2016

Viral shedding (median days)

Any dose CS = 14 (12 to 17 ) versus control = 12 (11 to 15$) ; P=0.027$

Low-moderate-dose CS $=13$ (10.3 to 16 ) versus control $=12$ (10.5 to 15$) ; P=0.252$

High-dose CS = 15 (13.5 to 20 ) versus control = 13 (10.8 to 15.3); $P=0.039$

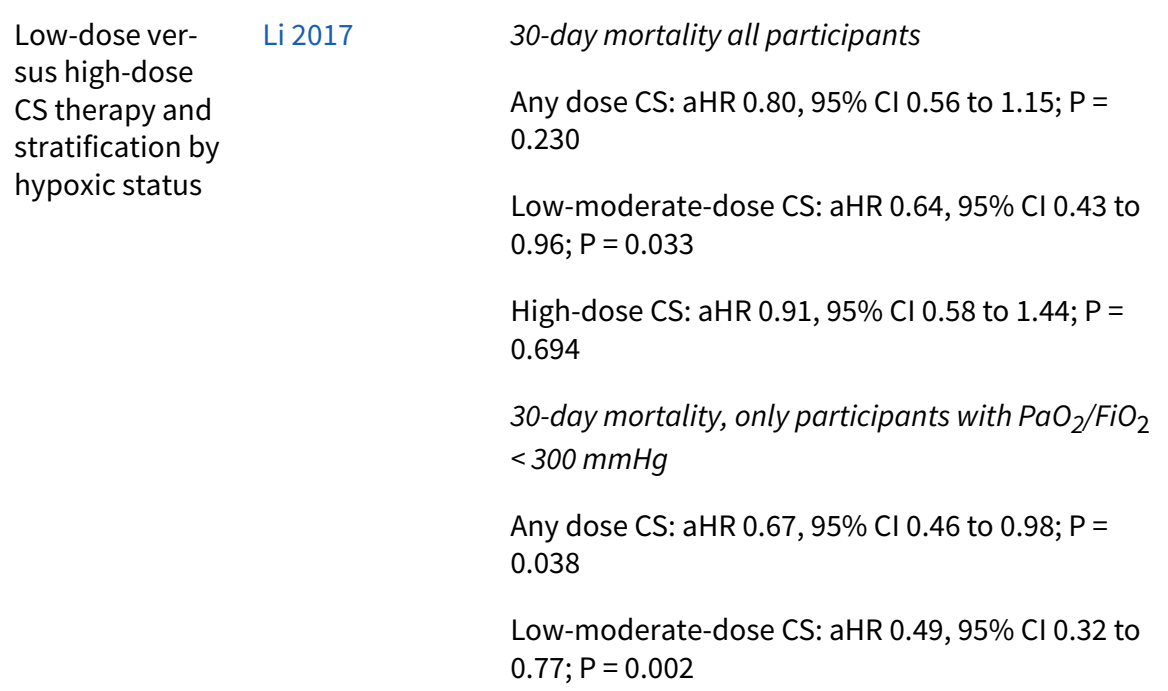

Low-moderate-dose CS therapy defined as 25 to $150 \mathrm{mg} /$ day methylprednisolone or equivalent.

High-dose CS therapy defined as $>150$ $\mathrm{mg} /$ day methylprednisolone or equivalent.

Propensity score adjusted analyses

Low-moderate-dose CS therapy defined as 25 to $150 \mathrm{mg} /$ day methylprednisolone or equivalent.

High-dose CS therapy defined as $>150$ $\mathrm{mg} /$ day methylprednisolone or equivalent. 
Table 4. Summary of studies reporting outcomes stratified according to different corticosteroid regimens (Continued)

High-dose CS: aHR $0.88,95 \% \mathrm{Cl} 0.56$ to $1.39 ; \mathrm{P}=$

0.581

30-day mortality, only participants with $\mathrm{PaO}_{2} / \mathrm{FiO}_{2}$

$\geq 300 \mathrm{mmHg}$

Any dose CS: aHR $2.43,95 \% \mathrm{Cl} 0.82$ to $7.15 ; \mathrm{P}=$

0.108

Low-moderate-dose CS: aHR 3.09, 95\% Cl 0.95 to

10.12; $P=0.062$

High-dose CS: aHR $1.70,95 \% \mathrm{Cl} 0.23$ to $12.65 ; \mathrm{P}=$

0.605

\section{aHR: adjusted hazard ratio}

$\mathrm{Cl}$ : confidence interval

CS: corticosteroid

HR: hazard ratio

$\mathrm{PaO}_{2} / \mathrm{FiO}_{2}$ : ratio of partial pressure of oxygen in arterial blood to inspired fraction of oxygen

RR: risk ratio

Table 5. Summary of studies reporting relevant outcomes other than mortality

\begin{tabular}{|c|c|c|c|c|}
\hline Outcome & Study & $\begin{array}{l}\text { Group treated } \\
\text { with corticos- } \\
\text { teroids }\end{array}$ & $\begin{array}{l}\text { Group not treat- } \\
\text { ed with corti- } \\
\text { costeroids }\end{array}$ & Unadjusted estimate of effect \\
\hline Critical disease & Han 2011 & Early CS & Late or no CS & $\mathrm{RR} 1.8,95 \% \mathrm{Cl} 1.2$ to $2.8 \dagger$ \\
\hline & & $12 / 17(70.6)$ & $26 / 66(39.4)$ & \\
\hline $\begin{array}{l}\text { Composite outcome of ICU } \\
\text { admission/death }\end{array}$ & Jain 2009 & $29 / 86(33.7)$ & $27 / 153(17.6)$ & OR $2.37,95 \% \mathrm{Cl} 1.29$ to 4.37 \\
\hline ICU admission & Li 2017 & $678 / 1055$ & $282 / 1086$ & OR $5.13,95 \% \mathrm{Cl} 4.26$ to 6.17 \\
\hline ICU admission & Wirz 2016 & $1 / 11(9.1)$ & $1 / 13(7.7)$ & OR $1.2,95 \% \mathrm{Cl} 0.07$ to 21.72 \\
\hline Rate of MV & Kim 2011 & $91 / 107(85.0)$ & $71 / 138(51.4)$ & OR $5.37,95 \% \mathrm{Cl} 2.87$ to 10.05 \\
\hline Rate of MV & $\begin{array}{l}\text { Linko } \\
2011\end{array}$ & $53 / 72(73.6)$ & $14 / 60(23.3)$ & OR $9.17,95 \% \mathrm{Cl} 4.14$ to 20.30 \\
\hline Rate of MV & Li 2017 & $367 / 1055(34.8)$ & $49 / 1086(4.5)$ & OR $11.29,95 \% \mathrm{Cl} 8.25$ to 15.44 \\
\hline Rate of MV & $\begin{array}{l}\text { Moreno } \\
2018\end{array}$ & $506 / 604(83.8)$ & $921 / 1242(74.2)$ & OR $1.78,95 \% \mathrm{Cl} 1.35$ to 2.35 \\
\hline $\begin{array}{l}\text { Length of ICU stay: median } \\
\text { days (IQR) }\end{array}$ & $\begin{array}{l}\text { Brun- } \\
\text { Buisson } \\
2011\end{array}$ & 22 (13 to 39) & 17 (11 to 30$)$ & $P=0.11$ \\
\hline $\begin{array}{l}\text { Length of ICU stay: median } \\
\text { days (IQR) }\end{array}$ & $\begin{array}{l}\text { Moreno } \\
2018\end{array}$ & $10(5$ to 19$)$ & $8(5$ to 18$)$ & $P=0.50$ \\
\hline LOS: mean days (SD) & Kim 2011 & $30.8(36.9)$ & $18.9(20.0)$ & $P<0.001$ \\
\hline
\end{tabular}


Table 5. Summary of studies reporting relevant outcomes other than mortality (Continued)

\begin{tabular}{|c|c|c|c|c|}
\hline $\begin{array}{l}\text { LOS: } \\
\text { median days (IQR) }\end{array}$ & Kudo 2012 & 8.2 (5 to 14$)$ & 7.7 (3 to 14$)$ & $P=0.607$ \\
\hline LOS: median days (IQR) & $\begin{array}{l}\text { Linko } \\
2011\end{array}$ & 20 (12 to 34$)$ & $8(5$ to 13$)$ & $P<0.001$ \\
\hline LOS & $\begin{array}{l}\text { Al-Busaidi } \\
2016\end{array}$ & Not reported & Not reported & $\begin{array}{l}\text { MV coefficient } 2.06,95 \% \mathrm{Cl} 1.55 \text { to } 2.74 \text { (adjust- } \\
\text { ed for severity) }\end{array}$ \\
\hline LOS & Lee 2015 & Not reported & Not reported & $\begin{array}{l}\text { Beta coefficient }=3.15(95 \% \mathrm{Cl} 2.19 \text { to } 4.10) ; \mathrm{P}< \\
0.001\end{array}$ \\
\hline $\begin{array}{l}\text { Time to effective hospital } \\
\text { discharge: mean days (SD) }\end{array}$ & Wirz 2016 & $9.2(9.4)$ & $10.4(8.0)$ & $\begin{array}{l}\text { Unadjusted difference }-1.57,95 \% \mathrm{Cl}-8.78 \text { to } \\
5.65 \text {; adjusted difference }-2.24,95 \% \mathrm{Cl}-9.61 \text { to } \\
5.12\end{array}$ \\
\hline $\begin{array}{l}\text { Hospital readmission at } 30 \\
\text { days postdischarge }\end{array}$ & Wirz 2016 & $1 / 11(9.1)$ & $1 / 13(7.7)$ & $\begin{array}{l}\text { OR } 1.2,95 \% \mathrm{Cl} 0.07 \text { to } 21.72 ; \text { aOR } 1.01,95 \% \mathrm{Cl} \\
0.03 \text { to } 37.36\end{array}$ \\
\hline $\begin{array}{l}\text { Time to clinical stability: } \\
\text { median days (IQR) }\end{array}$ & Wirz 2016 & $4.0(1.4$ to 7.0$)$ & $5.0(3.0$ to 10.4$)$ & $\begin{array}{l}\text { Unadjusted HR } 1.26,95 \% \mathrm{Cl} 0.54 \text { to } 2.92 \text {; ad- } \\
\text { justed HR } 4.50,95 \% \mathrm{Cl} 1.17 \text { to } 17.25\end{array}$ \\
\hline
\end{tabular}

aOR: adjusted odds ratio

$\mathrm{Cl}$ : confidence interval

CS: corticosteroid

HR: hazard ratio

ICU: intensive care unit

IQR: interquartile range

LOS: length of stay

MV: mechanical ventilation

OR: odds ratio

RR: risk ratio

SD: standard deviation

† Adjusted risk ratio $1.8,95 \% \mathrm{Cl} 1.2$ to 2.8 (following adjustment for comorbid illnesses, age, pregnancy, and obesity).

Table 6. Summary of studies reporting corticosteroid-related adverse events or nosocomial infection

\begin{tabular}{lllll}
\hline Adverse effect & Study & $\begin{array}{l}\text { Group treated } \\
\text { with corticos- } \\
\text { teroids }\end{array}$ & $\begin{array}{l}\text { Group not treat- } \\
\text { ed with corticos- } \\
\text { teroids }\end{array}$ & Unadjusted estimate of effect \\
\hline ICU-acquired infection & $\begin{array}{l}\text { Brun- } \\
\text { Buisson } \\
2011\end{array}$ & $38 / 83(45.8)$ & $44 / 125(35.2)$ & OR 1.55, 95\% Cl 0.88 to 2.74 \\
\hline Hospital-acquired infection & Kim 2011 & $54 / 107(50.5)$ & $24 / 138(17.4)$ & OR 4.84, 95\% Cl 2.71 to 8.65 \\
\hline Hospital-acquired infection & Viasus & $6 / 37(16.2)$ & $4 / 129(3.1)$ & OR 6.05, 95\% Cl 1.61 to 22.75 \\
\hline Hospital-acquired infection & Cao 2016 & $17 / 65(26.2)$ & $18 / 65(27.2)$ & OR 0.92, 95\% Cl 0.42 to 2.00 \\
\hline Hospital-acquired infection & $\begin{array}{l}\text { Delaney } \\
2016\end{array}$ & $92 / 265(32.8)$ & $89 / 310(27.5)$ & OR $1.32,95 \% \mathrm{Cl} 0.93$ to 1.88 \\
\hline Hospital-acquired infection & Lee 2015 & $58 / 600(9.7)$ & $55 / 2049(2.7)$ & $\mathrm{P}<0.001$ \\
\hline \hline
\end{tabular}


Table 6. Summary of studies reporting corticosteroid-related adverse events or nosocomial infection (Continued)
Hospital-acquired infection
Li 2017
$227 / 1055(21.5)$
$46 / 1086(4.2)$
OR $6.20,95 \% \mathrm{Cl} 4.46$ to 8.62

$\mathrm{Cl}$ : confidence interval

ICU: intensive care unit

OR: odds ratio

\section{AP PE N DICES}

\section{Appendix 1. MEDLINE (Ovid) and CENTRAL search strategy}

1 Influenza, Human/

2 exp Influenzavirus A/

3 exp Influenzavirus B/

4 (influenza* or flu).tw.

5 (h1n1 or h5n1 or h3n2).tw.

6 or/ $1-5$

7 exp Adrenal Cortex Hormones/

8 corticosteroid ${ }^{*}$.tw,nm.

9 adrenal cortex hormon*.tw.

10 (adren $^{\star}$ cortic $^{\star}$ adj1 (hormone* or steroid $\left.\left.{ }^{\star}\right)\right)$.tw.

11 adrenocorticosteroid ${ }^{\star}$. tw, nm.

12 adrenocorticoid ${ }^{*}$. tw, nm.

13 corticoid $^{*}$.tw, nm.

14 glucocorticoid ${ }^{\star}$.tw, nm.

15 hydroxycorticosteroid ${ }^{\star}$. tw,nm.

16 exp Steroids/

17 steroid $^{*}$. tw, nm.

18 (hydrocortisone $^{\star}$ or prednisolone ${ }^{\star}$ or prednisone ${ }^{\star}$ or dexamethasone* or methylprednisolone ${ }^{\star}$.tw,nm.

19 or/7-18

206 and 19

\section{Appendix 2. Embase (Elsevier) search strategy}

\#42 \#18 AND \#41

\#41 \#26 OR \#40

\#40 \#27 OR \#28 OR \#29 \#30 OR \#31 OR \#32 OR \#33 OR \#34 OR \#35 OR \#36 OR \#37 OR \#38 OR \#39

\#39 ('cross sectional' NEXT/1 (study OR studies)):ab,ti

\#38 (epidemiologic* NEXT/1 (study OR studies)):ab,ti

\#37 (observational NEXT/1 (study OR studies)):ab,ti

\#36 ('follow up' NEXT/1 (study OR studies)):ab,ti

\#35 ('case control' NEXT/1 (study OR studies)):ab,ti

\#34 (cohort NEXT/1 (study OR studies)):ab,ti

\#33 'cohort analysis'/de

\#32 'prospective study'/de

\#31 'retrospective study'/de

\#30 'longitudinal study'/de

\#29 'family study'/de

\#28 'case control study'/de

\#27 'clinical study'/de

\#26 \#21 NOT \#25

\#25 \#22 NOT \#24

\#24 \#22 AND \#23

\#23 'human'/de

\#22 'animal'/de OR 'nonhuman'/de OR 'animal experiment'/de

\#21 \#19 OR \#20

\#20 random*:ab,ti OR placebo*:ab,ti OR crossover*:ab,ti OR 'cross over':ab,ti OR allocat*:ab,ti OR trial:ti OR (doubl* NEXT/1 blind*):ab,ti \#19 'randomized controlled trial'/exp OR 'single blind procedure'/exp OR 'double blind procedure'/exp OR 'crossover procedure'/exp \#18 \#5 AND \#17 
\#17 \#6 OR \#7 OR \#8 OR \#9 OR \#10 OR \#11 OR \#12 OR \#13 OR \#14 OR \#15 OR \#16

\#16 hydrocortisone*:ab,ti OR prednisolone*:ab,ti OR prednisone*:ab,ti OR dexamethasone*:ab,ti OR methylprednisolone* $: a b, t i$

\#15 steroid*:ab,ti

\#14 'steroid'/exp

\#13 hydroxycorticosteroid*:ab,ti

$\# 12$ glucocorticoid*:ab,ti

\#11 corticoid ${ }^{\star}:$ ab,ti

$\# 10$ adrenocorticoid ${ }^{*}: \mathrm{ab}, \mathrm{ti}$

\#9 adrenocorticosteroid* $:$ ab,ti

\#8 (adren* NEAR/2 (hormon* OR steroid*)):ab,ti

\#7 corticosteroid* ${ }^{*}$ ab,ti

\#6 'corticosteroid'/exp

\#5 \#1 OR \#2 OR \#3 OR \#4

\#4 h1n1:ab,ti OR h5n1:ab,ti OR h3n2:ab,ti

\#3 influenza*:ab,ti OR flu:ab,ti

\#2 'influenza virus a'/exp OR 'influenza virus b'/de

\#1 'influenza'/exp

\section{Appendix 3. CINAHL (EBSCO) search strategy}

\section{S17 S7 OR S8 OR S9 OR S10 OR S11 OR S12 OR S13 OR S14 OR S15 OR S16}

S16 TI (hydrocortisone* or prednisolone ${ }^{\star}$ or prednisone* or dexamethasone* or methylprednisolone ( $^{\star}$ OR AB (hydrocortisone ${ }^{\star}$ or

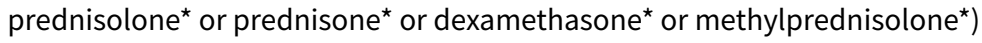

S15 TI steroid* OR AB steroid*

S14 (MH "Steroids+")

S13 TI hydroxycorticosteroid* OR AB hydroxycorticosteroid*

S12 TI glucocorticoid $^{*}$ OR AB glucocorticoid ${ }^{*}$

S11 TI corticoid* OR AB corticoid*

S10 TI adrenocortic* OR AB adrenocortic*

S9 TI (adren* N2 (hormone* or steroid $\left.\left.{ }^{\star}\right)\right)$ OR AB (adren* N2 (hormone* or steroid $\left.\left.{ }^{\star}\right)\right)$

S8 TI corticosteroid* OR AB corticosteroid*

S7 (MH "Adrenal Cortex Hormones+")

S6 S1 OR S2 OR S3 OR S4 OR S5

S5 TI (h1n1 or h5n1 or h3n2) OR AB ( h1n1 or h5n1 or h3n2)

S4 TI (influenza* or flu) OR AB (influenza* or flu)

S3 (MH "Influenza B Virus")

S2 (MH "Influenzavirus A+")

S1 (MH "Influenza+")

\section{Appendix 4. LILACS (BIREME) search strategy}

(mh:"Influenza, Human" OR influenza\$ OR flu OR grippe OR or gripe OR mh:"Influenzavirus A" OR mh:b04.820.545.405\$ OR mh:b04.909.777.545.405\$ OR mh:"Influenzavirus B" OR mh:b04.820.545.407\$ OR mh:b04.909.777.545.407\$ OR h1n1 OR h5n1 OR h3n2) AND (mh:"Adrenal Cortex Hormones" OR mh:d06.472.040\$ OR corticoesteroides OR corticosteróides OR corticoid\$ OR corticosteroid\$ OR "adrenal cortex hormone" OR "adrenal cortex hormones" OR adrenocorticosteroid\$ OR glucocorticoid\$ OR hydroxycorticosteroid \$ OR mh:glucocorticoids OR glucocorticóides OR mh:steroids OR esteróides OR mh:d04.808\$ OR hydrocortison\$ OR hidrocortisona OR mh:prednisolone OR prednisolone OR prednisolona OR mh:prednisone OR prednisone OR prednisona OR mh:dexamethasone OR dexamethasone OR dexametasona OR mh:methylprednisolone OR methylprednisolone OR metilprednisolona) AND db:("LILACS") AND type_of_study:("clinical_trials" OR "case_control" OR "cohort" OR "overview" OR "systematic_reviews")

\section{Appendix 5. Web of Science (Thomson Reuters) search strategy}

\begin{tabular}{|l|l|}
\hline$\# 5$ & 361 \\
\hline & \\
\hline \# & \\
\hline & $2,897,717$ \\
\hline & \\
\hline
\end{tabular}




\begin{tabular}{|l|l|}
\hline \#3 & $1,700,524$ \\
\hline & \\
\hline$\# 2$ & $1,425,723$ \\
\hline & \\
\hline$\# 1$ & 1,082 \\
\hline
\end{tabular}

WHAT'S NEW

\begin{tabular}{lll}
\hline Date & Event & Description \\
\hline 13 September 2019 & Amended & $\begin{array}{l}\text { A review author (CR) amended his declaration of interest state- } \\
\text { ment in response to a request by the Cochrane Funding Arbiter. }\end{array}$ \\
\hline
\end{tabular}

\section{H I S T O R Y}

Protocol first published: Issue 2, 2013

Review first published: Issue 3, 2016

\begin{tabular}{|c|c|c|}
\hline Date & Event & Description \\
\hline 3 October 2018 & $\begin{array}{l}\text { New citation required but conclusions } \\
\text { have not changed }\end{array}$ & Our conclusions remain unchanged. \\
\hline 3 October 2018 & New search has been performed & $\begin{array}{l}\text { A new author (LL) joined the review team. } \\
\text { We updated the searches and included } 12 \text { new studies (Al-Busai- } \\
\text { di 2016; Cao 2016; Delaney 2016; Huang 2017; Kinikar 2012; Lee } \\
\text { 2015; Li 2017; Moreno 2018; Ono 2016; Sheu 2017; Wirz 2016; Yu } \\
\text { 2011a). We excluded one previously included study (Diaz 2012), } \\
\text { as it has been superceded by a later study (Moreno 2018). We } \\
\text { excluded } 19 \text { new studies (Chen 2010; Chien 2010; Chotpitaya- } \\
\text { sunondh 2005; Dominguez-Cherit 2016; Hien 2009; Hong 2013; } \\
\text { Jung 2011; Leon 2017; Perez-Padilla 2009; Rios 2011; Segaloff } \\
\text { 2017; Singh 2017; Sun 2010; Torres 2012; Vilar-Compte 2018; Yale } \\
\text { 2015; Yang 2015a; Zhang 2011; Zhang 2013). }\end{array}$ \\
\hline
\end{tabular}

\section{CONTRIBUTIONS OF AUTHORS}

All of the review authors of the original version designed and conceived the systematic review. For this 2018 update, one review author (CR) extracted data from all eligible studies in the original version, and one review author (LL) extracted data for all eligible studies identified for this update using a standardised pro forma that was previously piloted and specifically adapted for this review. The other review authors shared the duplicate data extraction of all included studies. Two review authors (CR, LL) performed data synthesis and quantitative analyses. One review author (LL) drafted the updated review, and all co-authors critically reviewed the draft review prior to submission. 


\section{DECLARATIONS OF INTEREST}

Louise Lansbury is Head of the WHO Collaborating Centre for Pandemic Influenza and Research at the University of Nottingham, which has a grant pending from the World Health Organization to provide technical assistance for the prevention and control of seasonal influenza. The study is unrelated to the submitted work. LL's salary is funded by the National Institute for Health Research.

Chamira Rodrigo was employed by Nottingham University Hospitals NHS Trust (NUH), and not a commercial organisation during his time as a clinical research fellow. NUH received unrestricted funding from Pfizer and the National Institute for Health Research (NIHR) for unrelated research, to which he contributed as a research investigator.

Professor Jo Leonardi-Bee was a co-applicant on an educational grant from Hoffmann-La Roche to carry out research in the area of pandemic influenza. Hoffmann-La Roche did not support any aspects of this work. JLB undertook consultancy work for the UK Food Standards Agency in 2013-2015, and for a Breast Milk Substitute manufacturer in 2017, to help them design a healthcare claim trial.

Jonathan Nguyen-Van-Tam: The University of Nottingham Health Protection Research Group currently holds an unrestricted educational grant for influenza research from F. Hoffmann-La Roche. The aforementioned funding received from F. Hoffmann-La Roche did not support any aspect of this work. JNVT has received consultancy fees from two biopharmaceutical entities that have no licensed products anywhere in the world, as well as fees related to medico-legal work on influenza, and royalties related to academic work. He is a former employee of SmithKline Beecham plc (now GlaxoSmithKline), Roche Products Ltd, and Aventis-Pasteur MSD (now Sanofi-Pasteur MSD), all prior to 2005, with no outstanding pecuniary interests by way of shareholdings, share options, or accrued pension rights. He is currently on secondment to the Department of Health and Social Care (UK Government).

Wei Shen Lim's institution has received an unrestricted investigator-initiated research grant from Pfizer in support of a study in pneumococcal pneumonia that is unrelated to the submitted work; WSL is the Chief Investigator of the study. WSL's institution has received research funding from the National Institute for Health Research for a clinical trial of corticosteroids in pandemic influenza; WSL is the Chief Investigator.

\section{DIFFERENCES BETWEEN PROTOCOLAND REVIEW}

We updated the Objectives of this review to add "taking into account differences in timing and doses of corticosteroids".

We amended the Types of studies to state: "We excluded studies with case-control designs due to the inability to determine temporal effects of corticosteroids on the development of non-mortality outcomes. We excluded studies with fewer than 10 participants."

Stratification by 30-day mortality was not possible as stated in the protocol due to the heterogeneity across studies when reporting mortality. All the studies were conducted at least in part in a hospital setting, and stratification of outcomes according to in-/outpatient setting was not possible. We could not perform subgroup analyses according to corticosteroid regimens and age of study participants as there was an insufficient number of studies reporting outcomes stratified according to these variables. We were not able to perform sensitivity analysis to assess the effect of study design on primary and secondary outcomes as all the studies included in the meta-analyses were cohort studies.

\section{N DEX TERMS}

\section{Medical Subject Headings (MeSH)}

Adrenal Cortex Hormones [adverse effects] [*therapeutic use]; Chemotherapy, Adjuvant [adverse effects]; Cross Infection [etiology] [mortality]; Hospital Mortality; Influenza A Virus, H1N1 Subtype; Influenza, Human [ ${ }^{\star}$ drug therapy] [mortality]; Intensive Care Units [statistics \& numerical data]; Observational Studies as Topic; Randomized Controlled Trials as Topic; Respiration, Artificial [statistics \& numerical data]

\section{MeSH check words}

Humans 